Avoimesti luettavissa osoitteessa http://journal.fi/ainedidaktiikka

ainedidaktiikka

\title{
Ajattelun taidon tasot maantieteen ylioppilaskokeessa taloudellisen kestävän kehityksen koekysymyksissä ja vastauksissa
}

\author{
Julia Leivo, Olli Ruth ja Petteri Muukkonen \\ Matemaattis-luonnontieteellinen tiedekunta, Helsingin yliopisto
}

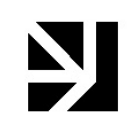

Tutkimme artikkelissamme sitä, miten ajattelun taidon tasot ilmenevät maantieteen ylioppilaskokeen taloudellista kestävää kehitystä käsittelevissä kysymyksissä sekä esseevastauksissa. Kestävään kehitykseen liittyvät ylioppilaskoekysymykset ovat usein vaativia, koska ne ovat tietoa laajasti soveltavia ja niissä yhdistetään useiden maantieteen kurssien ja muiden oppiaineiden sisältöjä. Luokittelimme kahden ylioppilaskoekysymyksen tehtävänannot ja niissä vaadittavat ajattelun taidon tasot Bloomin taksonomian mukaan ja vastaukset SOLO-taksonomian mukaan. Tehtävänannot edellyttivät pääasiassa ymmärtämistä, soveltamista, analysointia ja arvioimista. Keskimäärin vastausten ajattelun taidon tasot jäivät tehtävänantojen vaatimuksista noin puoliväliin. Harvat parhaista ylsivät vaaditulle tasolle vastauksissaan. Sisällönanalyysin perusteella opiskelijat hallitsivat hyvin reiluun kauppaan ja luonnonvarojen kestämättömään käyttöön liittyviä sisältöjä, mutta osasivat heikosti taloudellisen kestävän kehityksen perimmäisen ajatuksen. Vastauksista puuttui myös pohdintaa tulojen epätasaisesta jakautumisesta lähde- ja kohdemaan välillä. Tulosten perusteella suosittelemme lukion maantieteen opettajia keskittymään entistä enemmän sen varmistamiseen, että opiskelijat ymmärtävät teemojen syvemmän luonteen ja problematiikan. Vastaustekniikkaa, esseevastausten jäsentelyä ja syy-seuraussuhteiden perustelemista tulisi harjoitella entistä enemmän.

Bloomin taksonomia, lukio, oppilasarviointi, SOLO-taksonomia, taloudellinen kestävä kehitys, ylioppilaskoe

Lähetetty: 6.5.2020

Hyväksytty: 1.11.2020

Vastuukirjoittaja: petteri.muukkonen@helsinki.fi

DOI: $10.23988 /$ ad.92201 


\section{Johdanto}

Kestävän kehityksen asenteiden ja arvojen omaksumisessa kasvatuksella ja opetuksella on keskeinen rooli (Tuncer \& Sahin, 2016). Onnistuessaan ympäristöä ja kestävää kehitystä käsittelevä opetus lisää oppilaan ja opiskelijan tietoisuutta sekä ohjaa kohti yksilön vastuuta ja merkitystä yhteiskunnallisissa kysymyksissä (Charles, 1996). Ympäristöpetus on monialaista, mutta maantieteellä on siinä erityisen merkittävä rooli (Torbjörnsson \& Molin, 2014), koska maantieteen opetuksessa on keskeistä juuri ihmisen ja ympäristön välinen vuorovaikutus (Morgan, 2011). Monialaisuus näkyy muun muassa opetuksen eheyttämisenä, jossa monimutkaisia ilmiöitä opetetaan monitieteisesti (Cantell, 2015). Esimerkiksi perusopetuksessa on alettu puhua monialaisista oppimiskokonaisuuksista (Opetushallitus, 2014, ss. 31-33), jotka osaltaan auttavat opettajia ja opetuksen järjestäjiä luotsaamaan oppilaita tutustumaan ja tarkastelemaan myös monimutkaisia ilmiöitä - kuten ympäristö- ja kestävän kehityksen aiheita. Voidaan siis todeta, että vastatessaan kestävään kehitykseen liittyvään tehtävänantoon ylioppilaskokeessa opiskelijalla on mahdollisuus ammentaa tietoa ja osaamista myös muista oppiaineista.

Koulu ei ole ainoa paikka, jossa opiskelijat oppivat kestävästä kehityksestä. Opiskelijat ovat saaneet jo aiempaa kokemusta ja tietämystä ympäristöstä ja luonnosta ennen opettajalta saamaansa formaalia ympäristö- ja kestävän kehityksen aiheisiin liittyvää opetusta (Rickinson ym., 2009, ss. 29-30). Nuoret ovat saaneet näitä kokemuksia esimerkiksi lapsena tehtyjen metsäretkien, erilaisten harrastusten tai seuraamiensa uutisten tai elokuvien kautta (Rickinson ym., 2009). Voidaan siis sanoa, että nykyajan nuorilla on ollut mahdollisuus saada tietoutta ja osaamista ympäristö- ja kestävän kehityksen aiheista monista eri lähteistä - niin formaaleista kuin ei-formaaleista. Koulun ulkopuolisista lähteistä saatavan tiedon ja osaamisen tasossa on opiskelijoiden välillä kuitenkin huomattavia eroja, kuten on eroja myös koulusta saatavassa tiedossa ja osaamisessa. Muun muassa Aarnio-Linnanvuori ja Ahvenisto (2013) ovat todenneet, että yksittäisen opettajan varaan jää huomattava vastuu kestävän kehityksen aiheiden opetuksessa, koska oppikirjoissa näitä asioita käsitellään usein pintapuolisesti eivätkä kestävän kehityksen aiheet näy oppikirjoissa selkeinä itsenäisinä kokonaisuuksina.

Tulevaisuuden valveutuneiden kansalaisten kasvattamiseen kuuluu ympäristö- ja kestävän kehityksen tietoisuuden lisäämisen lisäksi myös yleisiä tavoitteita kuten muun muassa korkeampien ajattelun taitojen kehittäminen. Tämä näkyy myös maantieteen opetuksessa. Suomalainen maantieteen lukio-opetus pyrkii opetussuunnitelmien (Opetushallitus, 2015) mukaisesti edistämään opiskelijoiden kykyä maantieteelliseen ajatteluun, kriittiseen pohdintaan sekä opitun soveltamiseen. Lukion päätteeksi opiskelijoiden osaamista arvioidaan ja mitataan ylioppilaskokeissa, jotka toimivat viimeisenä summatiivisena arviointina lukioopintojen lopussa. Ylioppilaskokeilla mitataan valtakunnallisesti kaikkien lukio-opiskelijoiden osaamisen taso verrattuna opetussuunnitelmien 
tavoitteisiin. Ylioppilaskokeen tärkeän roolin takia se omalta osaltaan ohjaa lukio-opetusta.

Ensimmäiset sähköiset ylioppilaskokeet pidettiin syksyllä 2016, ja maantiede oli ensimmäisten oppiaineiden joukossa tässä digitalisaatiossa (Linkola, 2016). Muutos loi uudenlaisia mahdollisuuksia mitata opiskelijoiden kokonaisvaltaista osaamista ja korkeampien ajattelun taitojen kehittymistä esimerkiksi erilaisten aineistojen hyödyntämisen, luomisen ja soveltamisen myötä. Maantieteessä tärkeät kartat, diagrammit ja muu geomedia voidaan nyt integroida entistä vahvemmin ylioppilaskokeeseen ja sitä kautta myös opetukseen. Näin tarjoutuu oiva mahdollisuus kehittää opiskelijoiden ajattelun ja osaamisen taitoja aikaisempaa monipuolisemmilla tavoilla. Maantieteelle merkityksellisessä tiedossa on tyypillisesti kolme tasoa: maantieteellisen tiedon muistaminen, suhteellinen tieto ja maantieteellinen ajattelu sekä vaihtoehtoisten tulevaisuuksien hahmottaminen ja kriittinen ajattelu (Lambert, 2017; Lambert ym. 2015). Maantieteen sähköisissä ylioppilaskokeissa vaaditaan Tanin, Cantellin ja Hilanderin (2020, s. 13) mukaan tyypillisesti noin 54 prosentissa kysymyksistä suhteellista tietoa ja maantieteellistä ajattelua, 32 prosentissa kysymyksistä vaihtoehtoisten tulevaisuuksien hahmottamista ja kriittistä ajattelua sekä 14 prosentissa kysymyksistä yksinkertaisesti maantieteellisen tiedon muistamista.

Tämän tutkimuksen tavoitteena on tutkia lukio-opiskelijoiden ajattelun taidon tasoja maantieteen ylioppilaskokeen kognitiivisesti haastavammissa tehtävänannoissa (kokeen osa III). Keskitymme kestävää kehitystä käsitteleviin kysymyksiin, koska ne ovat erinomainen tutkimuskohde tutkittaessa korkeampia ajattelun tasoja edellyttävää oppimista. Tätä tukee neljä näkökulmaa. Ensiksi kestävän kehityksen teemat ovat eri oppiaineiden oppisisältöjä yhdistäviä ja soveltavia (Aarnio-Linnanvuori, 2016), mikä edellyttää korkeampia ajattelun taitoja. Toiseksi kestävän kehityksen teemat maantieteen opetuksessa edellyttävät laaja-alaista osaamista myös maantieteellisten ilmiöiden syistä ja seurauksista sekä keinoista sopeutua niihin. Kolmanneksi kestävää kehitystä käsittelevä opetus on useimmiten arvoperusteista ja ongelmalähtöistä, mikä edelleen lisää tarvetta korkeammille ajattelun taidoille oppimisen syventämisessä ja opitun soveltamisessa. Neljänneksi kestävän kehityksen teemat ovat tärkeitä kasvatettaessa nuoria tulevaisuuden yhteiskunnan jäseniksi.

Koska kestävä kehitys on hyvin laaja ja monialainen kokonaisuus, keskitymme tässä tutkimuksessa ainoastaan taloudelliseen kestävään kehitykseen. Taloudellinen kestävyys tarkoittaa toimintaa, joka turvaa taloudellisen kehityksen alueellista epätasa-arvoisuutta lieventäen (World Commission on Environment and Development, 1987). Taloudellinen kestävyys ei ole irrotettavissa muista kestävän kehityksen ulottuvuuksista, koska YK:n Ympäristön ja kehityksen maailmankomission raportin mukaan taloudellisen kehityksen tulee aina tapahtua ekologisen kestävyyden ja ympäristön säilymisen puitteissa. Tätä tutkimuksemme rajausta tukee se, että taloudellisen sektorin kehittyminen vaikuttaa suoraan tai välillisesti myös ympäristön tilan kehitykseen.

Lähestymme tutkimusaihetta sekä maantieteen ylioppilaskokeiden tehtävänantojen että opiskelijoiden vastausten kannalta. Tutkimme toisaalta sitä, mitä ylioppilaskokeiden kysymysten tehtävänannoissa 
edellytetään ja toisaalta sitä, miten opiskelijat kykenevät tuomaan vastauksissaan esille korkeampia ajattelun taitoja. Pyrimme vastaamaan seuraaviin tutkimuskysymyksiin: 1) millaisia ajattelun taidon tasoja taloudellista kestävää kehitystä käsittelevät maantieteen ylioppilaskokeen tehtävänannot edellyttävät, 2) millaisia ajattelun taidon tasoja vastauksissa esiintyy sekä 3) mitä sisältöjä opiskelijat osaavat ja hallitsevat taloudellisesta kestävästä kehityksestä?

\section{Maantiede oppiaineena ja kasvatus kestävään kehitykseen}

Maantieteen ytimessä on luonnon ja ihmisen toiminnan välisten vuorovaikutusten tutkiminen erityisesti alueellisesta näkökulmasta (Gillette, 2015, s. 6). Lisäksi maantieteelle on ominaista luonnon ja yhteiskunnan ilmiöiden ja prosessien monialainen tarkastelu. Esimerkiksi luonnonmaantieteellinen osaaminen tukee ihmisen toiminnan syiden ja seurauksien ymmärtämistä luonnon näkökulmasta (Linkola, 2014; Tani ym., 2020, s. 14). Voidaan puhua maantieteellisestä ajattelusta, joka auttaa hahmottamaan ihmisen ja luonnon välisiä yhteyksiä ja vuorovaikutuksia eri mittakaavatasoilla ja mittakaavatasojen välillä paikalliselta tasolta aina globaaliin tasoon asti (Tani, 2017, s. 218).

Suomessa maantieteen, kuten muidenkin oppiaineiden, opetusta ohjaavat opetussuunnitelmat. Ensimmäisen yhtenäisen 1970-luvun opetussuunnitelman ja koulureformin jälkeen opetussuunnitelman perusteita on julkaistu noin kymmenen vuoden välein (Tani, 2014). Perusopetukselle ja lukiolle laaditaan erilliset opetussuunnitelman perusteensa (Opetushallitus, 2014; Opetushallitus, 2015). Opetussuunnitelmissa on vuosikymmenien kuluessa näkynyt muutos opetuksen ja oppimisen tavoitteissa (Tani, 2014). Huomiota kiinnitetään nykyään enemmän muun muassa ongelmanratkaisuun, ymmärtämiseen, kriittiseen ajatteluun ja oppimaan oppimiseen. Lisäksi nykyään korostetaan oppijan keskeistä ja aktiivista roolia oppimistapahtumassa. Maantieteen opetuksessa korostuu nykyään siis konstruktivistisen oppimiskäsityksen mukainen ajattelun taitojen kehittäminen ja uuden tiedon etsiminen ja soveltaminen (Cantell, 2011, s. 4).

Nyt käytössä olevat lukion opetussuunnitelman perusteet ovat vuodelta 2015, ja ne otettiin käyttöön elokuussa 2016 lukion aloittaneilla opiskelijoilla (Opetushallitus, 2015). Tällä hetkellä on jo julkaistu lukion opetussuunnitelman perusteet 2019, mutta ne otetaan käyttöön vasta 1.8.2021 alkaen tuolloin aloittaville lukion opiskelijoille (Opetushallitus, 2019). Yleisesti voidaan todeta, että opetussuunnitelmien jatkuva kehittäminen on ohjannut ajattelua kauemmas opettajan perinteisestä roolista oman tieteenalansa osaajana lähemmäs opiskelijan omaa tiedon rakentamista, mikä korostaa entistä enemmän ajattelun taitojen merkitystä ja oppimaan oppimisen taitoa (Linkola, 2014, s. 197; Tani, 2017, s. 212).

Nykyään lukiomaantiede käsittelee kestävään kehitykseen liittyviä aiheita globaaleina kysymyksinä ainoalla pakollisella maantieteen Maailma muutoksessa -kurssilla (Opetushallitus, 2015). Voidaan kuitenkin nähdä, että kestävä kehitys on enemmän tai vähemmän läsnä 
useissa maantieteellisissä ilmiöissä ja prosesseissa, joita opetetaan maantieteen valinnaisilla eli valtakunnallisilla syventävillä kursseilla. Kestävän kehityksen läsnäoloa maantieteen opetuksessa vahvistaa myös se, että lukion opiskelijan tulee opetussuunnitelman perusteiden (Opetushallitus, 2015) mukaan kyetä tunnistamaan, arvioimaan ja vertailemaan alueiden riskejä ja niiden herkkyyttä sekä ymmärtää ja osata analysoida maailman alueiden kehityksen suuntaa ja siihen vaikuttavia tekijöitä. Tavoitteena on myös se, että opiskelija ymmärtää paikallisia, alueellisia ja globaaleja ongelmia ja ilmiöitä ja näkee olemassa olevat ratkaisumahdollisuudet. Useat maantieteelliset ilmiöt ja prosessit on linkitettävissä kestävän kehityksen aiheisiin.

Ylevistä tavoitteista huolimatta opetussuunnitelman perusteiden mukainen maantieteen opetus ei tällä hetkellä välttämättä toteudu lukioissamme. Muun muassa Tani (2017) on kritisoinut, että maantieteen oppitunneilla opettajat joutuvat nykyään keskittymään entistä enemmän teknologian hyödyntämiseen opetuksessa, mikä vie aikaa maantieteellisen ajattelun ja peruskäsitteiden harjoittelulta ja näin ollen maantieteellisten ilmiöiden syvemmältä ymmärtämiseltä. Lisäksi pakollisten lukion maantieteen kurssien määrä pudotettiin kahdesta yhteen, kun valtioneuvosto hyväksyi loppuvuodesta 2014 asetuksen lukionkoulutuksen tavoitteista ja tuntijaosta, mikä oli pettymys maantieteilijöille ja opettajankouluttajille (Linkola, 2014). Tällä ei kuitenkaan ole merkitystä ylioppilaskokeisiin osallistuvien opiskelijoiden näkökulmasta, koska he ovat usein opiskelleet myös maantieteen syventävät lukion kurssit. Toisaalta pakollisen maantieteen kurssin sisältö ja opetus vaikuttavat siihen, kuinka houkuttelevana opiskelijat näkevät maantieteen ja päättävät opiskella maantiedettä lisää syventävillä kursseilla (Linkola, 2014, s. 197).

Sähköisen ylioppilaskokeen aikana syksystä 2016 lähtien maantieteen kokeeseen ilmoittautuneiden määrät ovat vaihdelleet noin 1900-2300 opiskelijan välillä ollen pienoisessa nousussa (Ylioppilastutkintolautakunta, 2020b). Ylioppilastutkintolautakunta (2018) on todennut, että opiskelijoiden tietojenkäsittelytaidot ovat kohtuullisen hyviä, mutta vastaustaidoissa on puutteita. Pyrimme tuottamaan tutkimuksellamme uutta tietoa näistä teemoista. Ylioppilaskokeiden tutkiminen on siinäkin mielessä tärkeää, koska Tanin ja muiden (2020, s. 15) mukaan aiemmat ylioppilaskokeet ohjaavat usein maantieteen opettajien opetusta esimerkiksi sen vuoksi, että vanhoja ylioppilaskokeita käytetään usein opetuksessa.

\section{Ajattelun taidon tasot ja niiden arviointi}

\section{Kohti ajattelun taitojen arvioimista}

Lukion opetussuunnitelman perusteiden (Opetushallitus, 2015) mukaan opiskelijaa tulisi ohjata tutkimaan ympäristöään, tutustumaan keskeisiin käsitteisiin ja teorioihin ja tunnistamaan niiden sekä osaamisen välisiä yhteyksiä. Opiskelijan tulisi myös oppia arvioimaan omaa osaamistaan ja soveltamaan oppimaansa tietoa alkuperäisen kontekstin ulkopuolella. Lisäksi oppimisprosessinsa tunnistava opiskelija kehittää samalla ajattelun taitojaan, ja oppii hyödyntämään niitä erilaisissa muuttuvissa tilanteissa. Maantieteen lukio-opetuksen tavoitteita ovat maantieteellisen tiedon 
ymmärtäminen, tulkitseminen, soveltaminen ja arvioiminen (Opetushallitus, 2015, s. 146). Toisin sanoen maantieteen opetuksessa pyritään kehittämään opiskelijoiden ajattelun taitoja.

Keskeisiä ajattelun taitoja ovat muistaminen, ymmärtäminen sekä soveltaminen, analysoiminen, arvioiminen ja luominen. Ajattelun taidon tasot voidaan jakaa alemman tason ajattelun taitoihin (lower-order cognitive skills, LOCS) ja korkeamman tason ajattelun taitoihin (higherorder cognitive skills, HOCS) (Zoller \& Pushkin, 2007). Alemman tason ajattelun taitoihin luetaan asioiden yksinkertainen tietäminen tai aikaisemmin opitun asian mieleen palauttaminen sekä sen soveltaminen yksinkertaisissa tilanteissa. Luonnontieteissä esimerkiksi käsitetehtävät luetaan alemman tason ajattelun taitoihin, kun taas korkeamman tason ajattelutaitoja ovat esimerkiksi kriittinen ajattelu, ongelmanratkaisutaidot, laaja pohdinta erilaisissa konteksteissa sekä arvioiva ajattelu (Aksela ym., 2012, s. 13). Avoimet, aiherajauksia ylittävät tehtävät puolestaan ovat korkean tason ajattelun taitoja vaativia tehtäviä.

Ajattelun taidon tasojen arvioiminen on usein haastavaa. Arviointi ei ensinnäkään saisi kohdistua pelkästään osaamiseen, vaan sen pitäisi kohdistua kaikkeen oppimiseen (Repo, 2005). Valtakunnalliset ylioppilaskokeet ovat summatiivisia arviointeja, joissa mitataan kaikkien lukioopiskelijoiden osaaminen. Tämä vastaa mielikuvaa siitä, että arviointi on kirjallinen koe, joka järjestetään opetuksen päätteeksi ja joka kattaa kaikki opetuksen aikana opitut asiat (Atjonen, 2007). Arvioinnin nähdään usein olevan joko määrällistä tai laadullista (Biggs, 1999). Määrällinen arviointi mittaa opittuja asioita sen mukaan, miten hyvin opiskelija osaa toistaa hänelle opetettua asiaa ilman oman ajattelun edellyttämistä. Laadullinen arviointi taas ohjaa opiskelijan omaa oppimisprosessia, jossa lopputulosta enemmän arvioidaan opiskelijan ajattelun taitoja ja oppimisen laatua sekä kehitystä. Näistä laadullinen arviointi voisi siis tulla paremmin kyseeseen arvioitaessa ajattelun taidon tasoja ylioppilaskokeissa.

\section{Bloomin taksonomia}

Opetuksen tavoitteiden saavuttaminen edellyttää, että tavoitteet ovat selviä sekä opettajalle että opiskelijoille. Tavoitteiden jakaminen osiin ja edelleen luokitteleminen tukee niiden saavuttamista. Eräs laajasti käytössä oleva tavoitteiden ja tehtävänantojen luokittelun malli on Bloomin (1956) taksonomia, joka on suunniteltu auttamaan opetuksen suunnittelua ja arviointia. Viimeisin päivitetty versio Bloomin taksonomiasta on vuodelta 2001 (Anderson \& Krathwohl, 2001). Taksonomian perusidea muistuttaa kognitiivisen oppimiskäsityksen jäsentelyä (mm. Engeström, 1984), ja sen avulla luokitellaan opetukselle asetettuja tavoitteita sekä niissä vaadittavia kognitiivisia taitoja eri tiedon tasoilla. Tiedon eri tasoille ominaista on se, että tiedon luonne muuttuu konkreettisemmasta abstraktimmaksi. Samalla kognitiiviset prosessit muuttuvat vaativammiksi lähtien muistamisesta ja ymmärtämisestä aina kohti korkeampia ajattelun taidon tasoja (Aksela ym., 2012; Anderson \& Krathwohl, 2001). 


\section{Ainedidaktiikka 4(3) (2020)}

Taulukko 1. Ajattelun taidon tasojen luokittelu Bloomin uudistetun taksonomian (Anderson \& Krathwohl, 2001) mukaan maantieteen kontekstiin sovitettuna. Taulukon idea pohjautuu sekä Krathwohlin (2002, s. 214) esittämään taulukkoon että kemian opetuksen vastaaviin taulukoihin (Aksela ym., 2012, s. 17; Tikkanen, 2010, s. 76).

\begin{tabular}{|c|c|c|c|}
\hline \multicolumn{2}{|c|}{ Pääluokka } & \multirow{2}{*}{\begin{tabular}{|l} 
Alaluokat \\
1.1 Tunnistaminen
\end{tabular}} & \multirow{2}{*}{\begin{tabular}{|l|} 
Esimerkkejä \\
$\begin{array}{l}\text { Oppija kykenee hakemaan tietoa muistista tehtävänannon } \\
\text { mukaisesti: esim. paikannimet }\end{array}$ \\
\end{tabular}} \\
\hline \multirow{11}{*}{ 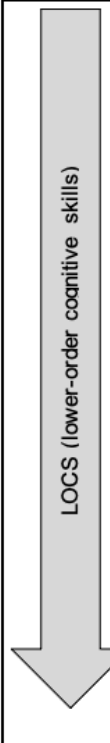 } & \multirow[t]{2}{*}{ 1. Muistaminen } & & \\
\hline & & 1.2 Mieleen palauttaminen & Oppija palauttaa tiedon muistista: esim. karttamerkit \\
\hline & \multirow[t]{7}{*}{$\begin{array}{l}2 . \\
\text { Ymmärtäminen }\end{array}$} & 2.1. Tulkitseminen & Oppija osaa muuttaa tietoa muodosta toiseen: esim. käsitteen selitys \\
\hline & & 2.2 Esimerkin antaminen & $\begin{array}{l}\text { Oppija osaa antaa havainnollistavia esimerkkejä käsitteistä, esim. } \\
\text { poimuvuoresta }\end{array}$ \\
\hline & & 2.3 Luokittelu & Oppija osaa luokitella esim. luonnonvaroja eri kategorioihin \\
\hline & & 2.4 Yhteenvedon tekeminen & $\begin{array}{l}\text { Oppija osaa tiivistää laajemman kokonaisuuden perusajatukset } \\
\text { esim. artikkelin pohjalta }\end{array}$ \\
\hline & & 2.5 Päättely & $\begin{array}{l}\text { Oppija kykenee loogiseen päättelykykyyn annetun tiedon pohjalta, } \\
\text { esim. väestön kasvun periaatteet alueellisesti tarkasteltuna }\end{array}$ \\
\hline & & 2.6 Vertaaminen & $\begin{array}{l}\text { Oppija osaa tunnistaa kahden eri teeman välisiä yhtäläisyyksiä ja } \\
\text { eroja: esim. käsitteiden vertailu }\end{array}$ \\
\hline & & 2.7 Perusteleminen & $\begin{array}{l}\text { Oppija osaa muodostaa syy-seuraussuhteita annetusta ilmiöstä } \\
\text { esim. muuttoliikkeen ja väestömäärän muutoksen välillä }\end{array}$ \\
\hline & \multirow[t]{2}{*}{$\begin{array}{l}3 . \\
\text { Soveltaminen }\end{array}$} & $\begin{array}{l}\text { 3.1 Menetelmän } \\
\text { toteuttaminen }\end{array}$ & $\begin{array}{l}\text { Oppija osaa soveltaa yksinkertaista menetelmää tutun tehtävän } \\
\text { ratkaisemiseen: esim. kartan lukeminen }\end{array}$ \\
\hline & & 3.2 Menetelmän käyttäminen & $\begin{array}{l}\text { Oppija osaa soveltaa menetelmää vieraan tehtävän ratkaisemiseksi: } \\
\text { esim. ongelmanratkaisutehtävä }\end{array}$ \\
\hline \multirow{8}{*}{ 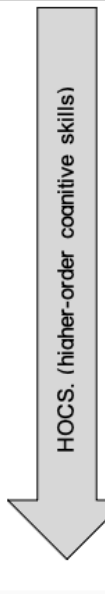 } & \multirow[t]{3}{*}{4.} & 4.1 Erotteleminen & $\begin{array}{l}\text { Oppija osaa poimia tehtävänannosta tärkeät ja olennaiset kohdat, } \\
\text { joita tehtävän ratkaiseminen edellyttää }\end{array}$ \\
\hline & & 4.2 Jäsentäminen & $\begin{array}{l}\text { Oppija tunnistaa tehtävästä olennaiset kohdat ja muodostaa niistä } \\
\text { kokonaisuuden: esim. tutkimusraportti }\end{array}$ \\
\hline & & $\begin{array}{l}\text { 4.3 Piilomerkitysten } \\
\text { tunnistaminen }\end{array}$ & $\begin{array}{l}\text { Oppija kykenee "lukemaan rivien välistä" ja tunnistaa näkökulmia, } \\
\text { ennakkoasenteita ja arvoja: esim. artikkelin kirjoittajan näkökulman } \\
\text { tulkitseminen }\end{array}$ \\
\hline & \multirow[t]{2}{*}{ 5. Arvioiminen } & 5.1 Tarkistaminen & $\begin{array}{l}\text { Oppija osaa tarkistaa tehtävien, aineistojen ja vastausten } \\
\text { oikeellisuuden ja virheettömyyden: esim. tutkimuksen tulosten } \\
\text { paikkansapitävyys }\end{array}$ \\
\hline & & 5.2 Arvosteleminen & $\begin{array}{l}\text { Oppija osaa arvostella tuotetta ulkoisten kriteerien pohjalta: esim. } \\
\text { luonnontieteiden menetelmien arvioiminen }\end{array}$ \\
\hline & \multirow[t]{3}{*}{ 6. Luominen } & 6.1 Kehittäminen & $\begin{array}{l}\text { Oppija osaa muodostaa hypoteeseja ja ratkaisutapoja annettujen } \\
\text { ohjeiden perusteella }\end{array}$ \\
\hline & & 6.2 Suunnitteleminen & $\begin{array}{l}\text { Oppija osaa suunnitella ratkaisumalleja annettuun ongelmaan: } \\
\text { esim. maastotyön suunnitteleminen }\end{array}$ \\
\hline & & 6.3 Tuottaminen & $\begin{array}{l}\text { Oppija osaa toteuttaa omaperäisen tuotoksen tehtävänannon } \\
\text { mukaisesti: esim. tehtävään soveltuva menetelmä }\end{array}$ \\
\hline
\end{tabular}

Bloomin taksonomiassa tavoitteen luokittelu vaatii sekä siihen liittyvän tekemisen (muistamisesta luomiseen, tasot 1-6) että tekemisen kohteen eli tiedon tason (faktatiedosta metakognitiiviseen tietoon, tasot A-D). Tekeminen edustaa kognitiivista osaamisen tasoa, tässä tapauksessa ajattelun taidon tasoja. Tekemisen kohde kuvailee tiedon tasoa, jonka oppilaan on tarkoitus kussakin kategoriassa saavuttaa. Alimman ajattelun taidon tasot ovat 1) muistaminen ja 2) ymmärtäminen. Muistaminen kattaa tunnistamisen ja mieleen palauttamisen. Ymmärtäminen on laajempi kokonaisuus ja se pitää sisällään tulkinnan, esimerkkien antamisen, luokittelun, tiivistämisen, päättelemisen, vertailun ja selittämisen. Kolmas ajattelun taidon taso on 3) soveltaminen. Tässä tasossa osaaminen on jo sellaista, että ennalta opittuja tietoja kyetään käyttämään uudenlaisissa konteksteissa. Kategorian verbit kattavat tiedon käyttämisen uudessa tilanteessa. Neljäs 
osaamisen taso on 4) analysointi. Tässä vaiheessa opittua tietoa ymmärretään niin vahvasti, että sen perusteella voidaan päätellä asioita tilanteista, joista tietoa ei entuudestaan ole kertynyt. Kategorialle tyypilliset verbit ovat erittely, jäsentely ja määrittely. Viides taso on 5) arviointi, joka pitää sisällään tarkistamisen ja aiheen kriittisen tarkastelun. Kuudes ja korkein osaamisen taso on 6) luominen. Tämä taso sisältää yleistämisen, suunnittelun sekä tuottamisen opittua tietoa hyödyntäen.

Edellä kuvatut ajattelun taidon tasot 1-6 ovat pääluokkia, jotka kukin voidaan edelleen jakaa 2-7 alaluokkaan. Taulukkoon 1 olemme luoneet maantieteen opetukseen sopivan ajattelun taitojen luokittelun uudistetulle Bloomin taksonomialle alaluokkineen (Krathwohl, 2002) ja esimerkkeineen. Idean taulukkoomme saimme kemian opettajankoulutuksen tutkijoiden Greta Tikkasen (2010) ja Maija Akselan, Greta Tikkasen ja Pirkko Kärnän (2012) aiemmin luomien taulukoiden pohjalta.

\section{SOLO-taksonomia}

Edellä kuvattu Bloomin taksonomia on kehitetty luokittelemaan opetuksen ja oppimisen tavoitteiden sekä tehtävänantojen vaatimuksia. Jos halutaan arvioida myös sitä, millaisia ajattelun taidon tasoja oppijat kykenevät tuomaan esimerkiksi avoimissa vastauksissa esille, täytyy käyttää vastauksen sisällön ja laadun syvyyttä kuvaavaa taksonomiaa. SOLO-taksonomia (Structure of Observed Learning Outcome; Biggs \& Collis, 1982) on runsaasti käytetty luokittelumenetelmä, kun halutaan tarkastella avoimien vastausten perusteella ajattelun taidon tasoja. Sen on todettu soveltuvan hyvin suomalaiseen koulutusjärjestelmään erityisesti perusopetuksen jälkeisille koulutustasoille, kun tutkitaan opiskelijoiden kognitiivista osaamista ja ajattelun taidon tasoja (Fahmy, 2018; Haapanen, 2018; Hannula, 2019; Havukainen, 2003; Koskinen, 2005).

Ajattelun taitojen mittaaminen ei kuitenkaan ole helppoa, koska oppiminen ei ole pelkästään opittujen asioiden yhteenlaskettu määrä, vaan myös opitun asian syvällisyys. Oppimisen määrällinen arviointi nähdään vielä helppona ja yksinkertaisena menetelmänä seurata opiskelijan lopullista oppimisen tasoa, kun taas laadullisen oppimisen mittaaminen nähdään olevan subjektiivisempaa (Biggs \& Collis, 1982). Opittujen asioiden määrällä ei kuitenkaan ole merkitystä silloin, kun kyse on opittujen tietojen ja taitojen soveltavasta käytöstä. Ajattelun taidon tasojen syvällisyyttä voidaan tulkita pääasiassa vain avoimien vastausten kuten esseevastausten avulla, koska tällöin opiskelijalta vaaditaan usein enemmän kuin vain opitun asian toistamista ulkomuistista.

SOLO-taksonomia sisältää viisi tasoa sekä niiden väliin jäävät niin sanotut siirtymävaiheet (taulukko 2). Kolme ensimmäistä tasoa (1-3) ovat mitattavissa kvantitatiivisesti. Kolmella viimeisellä tasolla (4-6) tiedon ja ajattelun taidon tasot ovat mitattavissa kvalitatiivisesti eli tiedon luonne on soveltavaa ja siinä olevaa tietomäärää ei voi laskea tai sillä ei ole merkitystä (Biggs \& Tang, 2011). 
Taulukko 2. Tutkimuksessamme käytetyt SOLO-taksonomian luokat (Biggs \& Collis, 1982; Biggs \& Tang, 2011).

\begin{tabular}{|c|c|c|c|}
\hline & SOLO-luokka & Vastausta kuvaavat verbit & Vastauksen ominaisuudet \\
\hline \multirow{9}{*}{ 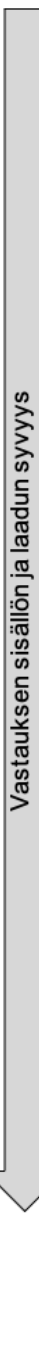 } & $\begin{array}{l}\text { 1. Esirakenteinen } \\
\text { vastaus }\end{array}$ & & $\begin{array}{l}\text { Vastaus on väärin tai kysymykseen ei vastata, ei asiaan } \\
\text { kuuluvaa näkökulmaa, väärään asiaan perehtyminen, } \\
\text { termin toisto vastauksessa, vastaa vain toiseen } \\
\text { kysymyksen osaan tai käyttää vääää termistöä, } \\
\text { mielipiteiden varaan perustettu vastaus. }\end{array}$ \\
\hline & $\begin{array}{l}\text { 1A. Esirakenteisen } \\
\text { siirtymävaihe }\end{array}$ & & $\begin{array}{l}\text { Tarkasteltu vain yhtä olennaista teemaa vajavaisesti, aihe } \\
\text { kiertää kehää. }\end{array}$ \\
\hline & $\begin{array}{l}\text { 2. Yksinkertainen } \\
\text { vastaus }\end{array}$ & $\begin{array}{l}\text { muistaa, identifioida, laskea, } \\
\text { tunnistaa, määritellä, kuvailla, } \\
\text { löytää, järjestää, yhteensovittaa, } \\
\text { nimetä, lainata, muistuttaa } \\
\text { mieleen, luetella, kertoa, } \\
\text { kirjoittaa, järjestää, jäljitellä }\end{array}$ & $\begin{array}{l}\text { Tarkasteltu yhtä oikeaa näkökulmaa laajemmin, termin } \\
\text { selitykset ulkomuistista. Vahva luettelomaisuus, } \\
\text { pinnallisuus, isoon kuvaan sopimattomat huomiot. }\end{array}$ \\
\hline & $\begin{array}{l}\text { 2A. Yksinkertaisen } \\
\text { siirtymävaihe }\end{array}$ & & $\begin{array}{l}\text { Tarkasteltu kahta olennaista teemaa pinnallisesti, } \\
\text { aineistoon vahvaa nojaamista ilman oman ajattelun } \\
\text { näkymistä, perustelemattomia väitteitä, punainen lanka } \\
\text { puuttuu, laajakin vastaus voi olla pinnallisesti tarkasteltu. }\end{array}$ \\
\hline & $\begin{array}{l}\text { 3. Monirakenteinen } \\
\text { vastaus }\end{array}$ & $\begin{array}{l}\text { luokitella, kuvailla, listata, } \\
\text { selvittää, keskustella, } \\
\text { havainnollistaa, valita, kertoa, } \\
\text { arvioida, eritellä, hahmotella }\end{array}$ & $\begin{array}{l}\text { Tarkasteltu kahta tai useampaa näkökulmaa, mutta } \\
\text { vallitsevia epäjohdonmukaisuuksia ja ristiriitoja ei } \\
\text { tunnisteta, teemojen luettelu loogisesti ilman perustelevia } \\
\text { päätelmiä tai aihealueiden kytkentöjä toisiinsa, syy- } \\
\text { seuraussuhteiden puuttuminen, ongelmien luetteleminen } \\
\text { ilman ratkaisuehdotuksia, esimerkkien puuttuminen, hyviä } \\
\text { oivalluksia ilman perusteluja. }\end{array}$ \\
\hline & $\begin{array}{l}3 \mathrm{~A} . \\
\text { Monirakenteisen } \\
\text { siirtymävaihe }\end{array}$ & & $\begin{array}{l}\text { Epäjohdonmukaisuudet tunnistetaan, mutta niihin ei } \\
\text { pureuduta syvemmin, syy-seuraussuhteiden tarkastelu } \\
\text { voimistuu. }\end{array}$ \\
\hline & $\begin{array}{l}\text { 4. Relationaalinen } \\
\text { vastaus }\end{array}$ & $\begin{array}{l}\text { soveltaa, integroida, analysoida, } \\
\text { selittää, päätellä, ennustaa, } \\
\text { tiivistää, kerrata, suunnitella, } \\
\text { argumentoida, luonnehtia, } \\
\text { rinnastaa, eritellä, organisoida, } \\
\text { keskustella, rakentaa, referoida }\end{array}$ & $\begin{array}{l}\text { Tarkasteltu useampaa näkökulmaa ja } \\
\text { epäjohdonmukaisuuksiin pureudutaan, mutta vielä syvää } \\
\text { analyysiä tai yleistyksiä aiheesta ei vielä tuoteta, syy- } \\
\text { seuraussuhteita tuodaan esiin enemmän ja vastaus etenee } \\
\text { loogisesti ja johdonmukaisesti, miellyttävä lukea. }\end{array}$ \\
\hline & $\begin{array}{l}\text { 4A. Relationaalisen } \\
\text { siirtymä }\end{array}$ & & $\begin{array}{l}\text { Jokin yleistys on tunnistettu, mutta sitä ei tulkita vielä } \\
\text { syvemmin vastauksessa. }\end{array}$ \\
\hline & 5. Laaja abstraktinen & $\begin{array}{l}\text { teoretisoida, tehdä hypoteesi, } \\
\text { yleistää, reflektoida, synnyttää } \\
\text { uutta, koostaa, keksiä, johtaa, } \\
\text { todistaa }\end{array}$ & $\begin{array}{l}\text { Laajempi vallitseva ilmiö on ymmärretty, vastaus on hyvin } \\
\text { eritelty ja ristiriidat sekä johtopäätökset on esitetty } \\
\text { selkeästi, epäjohdonmukaisuudet on tuotu esiin } \\
\text { onnistuneesti ja niitä on analysoitu syy-seuraus -suhteisiin } \\
\text { kytkettyinä, alueellinen näkökulma ja globaali tarkastelu } \\
\text { näkyy vastauksessa, perustelut ovat yhteen linkittyneitä, } \\
\text { eikä tekstissä esiinny luettelomaisuutta, mahdollisimman } \\
\text { monta näkökulmaa on tarkasteltu maantieteellistä } \\
\text { termistöä hyödyntäen. }\end{array}$ \\
\hline
\end{tabular}

\section{Aineisto ja menetelmät}

\section{Tutkittavat ylioppilaskoekysymykset}

Tutkimuksessamme analysoimme maantieteen ylioppilaskokeiden kahden kysymyksen tehtävänantoja (taulukko 3) sekä niiden vastauksia. Molemmat kysymykset käsittelivät taloudellista kestävää kehitystä (Ylioppilastutkintolautakunta, 2020c). Syksyn 2018 maantieteen kokeen tehtävä 7 käsitteli kahvia globaalista näkökulmasta. Tehtävä on kokeen kolmannesta eli viimeisestä ja vaativammasta osasta ja se sisältää tilasto- ja karttaaineistoja sekä diagrammin laatimista. Kevään 2019 tehtävä 6 käsitteli hiekkaa ehtyvänä luonnonvarana. Myös tämä kysymys on tasoltaan vaativampi, kokeen kolmannen osan tehtävä, joka sisältää kuva- ja tekstiaineistoa. Molemmissa tehtävissä edellytetään avointa teksti- eli esseevastausta. 
Ylioppilaskokeessa vastausaika on kuusi tuntia ja kokeen sisältö perustuu lukion opetussuunnitelmien perusteisiin. Kokeet sisältävät niin ainekohtaisia kuin oppiainerajat ylittäviä kysymyksiä. Maantieteen kokeessa on kolme osaa (I-III), joista osan I kysymys (20 p.) on kaikille pakollinen, osa II sisältää 20 pisteen kysymyksiä, joista opiskelija valitsee kaksi ( 2 x 20 p.) ja osa III sisältää 30 pisteen kysymyksiä, joista opiskelija valitsee kaksi (2 x 30 p.) (Ylioppilastutkintolautakunta, 2018). Osan I kysymykset ovat usein lyhyitä väittämä-, monivalinta-, yhdistely-, määrittely- tai selitystehtäviä. Osan III tehtävät vastaavat vanhan koemallin jokerikysymyksiä, eli ne edellyttävät korkeimpia ajattelun taitoja, ongelmanratkaisuja, maantieteellistä ymmärrystä ja ajattelua. Useimmiten kaikissa kokeissa kysymykset on jaettu muutamaan alakohtaan. Ylioppilastutkintolautakunnan julkaisemien hyvän vastauksen piirteiden mukaan maantieteen kokeessa arvioinnin kohteena ovat maantieteelliset tiedot ja taidot, niiden itsenäinen hallinta sekä kokelaan kyky soveltaa niitä (Ylioppilastutkintolautakunta, 2020a). Tehtävien usein laajojen asiasisältöjen vuoksi kokelailta vaaditaan laajaa asianhallintaa sekä vastauksen sitomista laajempiin asiayhteyksiin. Ylioppilastutkintolautakunta edellyttää myös, että esseevastaukset ovat jäsenneltyjä ja johdonmukaisia. Lisäksi syy-seuraussuhteiden tarkastelun tulee olla syvällistä ja perusteltua. Tani ja muut (2020, s. 15) ovat huomanneet, että sähköiseen maantieteen ylioppilaskokeeseen siirtymisen myötä kokeista on tullut keskimäärin vaativampia, koska osan III eli vanhojen jokerikysymysten tasoisten kysymysten määrä on kasvanut. Vastaavasti helpoimpien tehtävien lukumäärä on laskenut.

Taulukko 3. Maantieteen ylioppilaskokeiden syksyn 2018 kysymys 7: kahvi ja globalisaatio (30 p.) sekä kevään 2019 kysymys 6: Hiekka ehtyvänä luonnonvarana (30 p.) (Ylioppilastutkintolautakunta, 2020c).

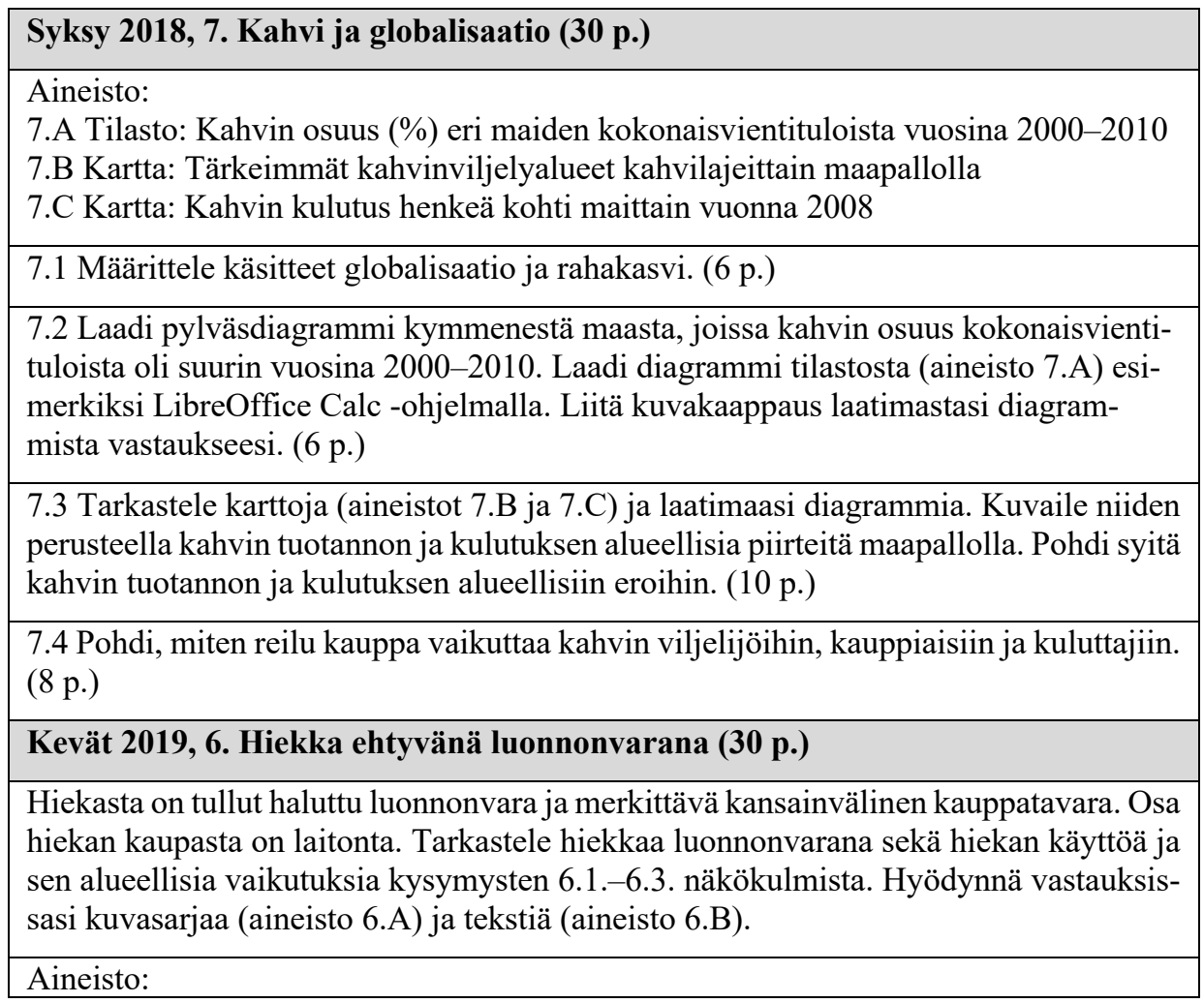


6.A Kuvasarja: Kuvasarja hiekanotosta ja hiekan käytöstä 6.B Teksti: Unohtakaa öljy, nyt loppuu hiekka

6.1 Mitä tarkoitetaan kivennäismaalajeilla, ja miten niitä luokitellaan? (4 p.) 6.2 Mihin hiekkaa tarvitaan, ja mitkä seikat vaikuttavat hiekan kulutukseen? (12 p.) 6.3 Mitä taloudellisia, yhteiskunnallisia ja ympäristöongelmia hiekan käyttöön luonnonvarana liittyy? Pohdi myös keinoja ongelmien ratkaisemiseksi. (14 p.) 6.1 Mitä tarkoitetaan kivennäismaalajeilla, ja miten niitä luokitellaan? (4 p.)

Syksyn 2018 kysymys 7 käsittelee kahvia globaalina vientituotteena ja raaka-aineena. Ylioppilastutkintolautakunta (2020a) on selvittänyt hyvän vastauksen piirteissä tehtävän kullekin osalle vaadittavat asiat. Tehtävässä arvioinnin kohteena olivat opiskelijan tiedot kahvintuotannosta ja siihen linkittyvistä tekijöistä maailmanlaajuisesti ja alueellisesti tarkasteltuna. Arvioitavia asioita olivat opiskelijan kyky käyttää annettua aineistoa ja tuottaa siitä diagrammi sekä tarkastella raaka-aineeseen liittyviä piirteitä ja niiden alueellisia eroja lähdeaineistojen avulla. Arvioinnissa huomioitiin myös opiskelijan kyky ymmärtää globalisaatiota ja käyttää täsmällisiä maantieteen termejä. Ylioppilastutkintolautakunnan (2020a) hyvän vastauksen piirteissä on eritelty lisäksi oikeita vastauksia kunkin alakohdan kohdalle. Tutkimuksessamme emme analysoi alakohtaa 7.2, koska siinä opiskelijoiden tehtävänä oli ainoastaan laatia pylväsdiagrammi.

Kevään 2019 kysymys 6 koski hiekkaa vientituotteena ja teollisuuden raaka-aineena. Tehtävänanto käsitteli luonnonvaran käyttöä ja sen merkitystä ilmiönä. Verrattuna esimerkiksi öljyyn hiekka esitetään harvemmin lukiossa esimerkkiluonnonvarana. Tämän vuoksi tehtävänantoon oli tarjottu lukuisia aineistoja, jotta kokelailla olisi jonkinlaista tarttumapintaa vastauksen kirjoittamiseen. Ylioppilastutkintolautakunnan (2020a) hyvän vastauksen piirteiden mukaan kysymyksessä arvioidaan opiskelijan osaamista ja kykyä analysoida hiekkaa luonnonvarana ja ymmärtää sen merkitystä eri näkökulmista kuten hiekkaa maalajina, hiekan hyödyntämistä sekä sen käyttöön liittyviä ongelmia ja niiden ratkaisumahdollisuuksia. Arvioinnin kohteena ovat aineiston tulkinta, maantieteellisten käsitteiden käyttö sekä asiayhteyksien analysointi. Hyvän vastauksen piirteissä on annettu oikeita vastausvaihtoehtoja kuhunkin alakohtaan.

Kysymysten tehtävänannot luokiteltiin kahdella tavalla. Ensiksi jokainen alakohta luokiteltiin erikseen päivitetyn Bloomin taksonomian (Anderson \& Krathwohl, 2001) ajattelun taitojen tasojen mukaan (vrt. taulukko 1). Tämän jälkeen koko kysymys sijoitettiin taksonomiaan kokonaisuutena alakohdista saadun korkeimman ajattelun taidon tason mukaan.

\section{Aineisto ylioppilaskokeen vastauksista}

\section{Luokittelu SOLO-taksonomiaan}

Tutkimustamme varten anoimme Ylioppilastutkintolautakunnalta tutkimuslupaa ja aineistoja molempien tutkittavien koekysymysten vastauksista. Ylioppilastutkintolautakunta toimitti satunnaisotantana 200 vastausta kumpaankin tutkimuksemme koekysymykseen. Hyväksytty tutkimuslupamme ei kattanut tietoa opiskelijoista, kouluista, koulupaikan sijainneista tai opiskelijoiden saamista pistemääristä. Näistä kahdesta koekysymyksestä analysoimme vastaavasti 120 ja 121 satunnaisesti valittua 
vastausta (nt7=120 ja nt6=121), koska vastausten sisällöllisen tarkastelun näkökulmasta aineisto saturoitui eli uusien vastausten läpikäyminen ei tuonut esille enää uutta liittyen vastausten sisältöihin ja vastauksissa esiintyvien ajattelun taidon tasojen sisältöön.

Vastaukset luki kolme kertaa läpi tutkija Julia Leivo, jonka maantieteen alan pro gradu -tutkielmaan tämä tutkimus pohjautuu (Leivo, 2020). Ensimmäisellä lukukerralla tarkoituksena oli saada kokonaiskäsitys käsiteltävästä aineistosta ja sen laadusta. Ensimmäisen lukukerran aikana tehtiin myös muokkauksia myöhemmin käytettävää luokittelutaulukkoa varten, jotta SOLO-taksonomia saatiin vastaamaan aineiston ominaispiirteitä. Toisella lukukerralla vastaukset luokiteltiin SOLO-taksonomian (Biggs \& Collis, 1982; Biggs \& Tang, 2011) mukaan, ja kolmannella lukukerralla vastausten luokitteluja tarkistettiin ja varmistettiin. Opiskelija sai SOLO-taksonomian mukaisen luokittelun tason vastauksestaan sen mukaan, mikä oli hänen korkein tasonsa eri alakohdat huomioiden, koska eri alakohdissa ajattelun taidon tasojen vaatimukset olivat erilaiset. Tämän tutkimuksen SOLO-taksonomian luomisessa käytettiin apuna Ylioppilastutkintolautakunnan (2020a) hyvän vastauksen piirteitä.

Ylioppilastutkintolautakunnan (2020a) hyvän vastauksen piirteissä painotettiin oikeiden asioiden lukumäärää vastauksessa, mutta emme ottaneet tätä huomioon yhtä vahvasti SOLO-taksonomiassamme (vrt. taulukko 2). Vaikka oikeiden asioiden lukumäärä vastauksessa on merkitty taksonomiaan, painotimme vastauksen luokittelussa enemmän muita vastauksen piirteitä. Jos vastaukset sisälsivät useita SOLO-taksonomian elementtejä, sijoitettiin ne sellaiseen luokkaan, jonka ominaisuuksia vastaus kokonaisuutena edusti parhaiten. Joissain vastauksissa kokelaat vastasivat asiasisällöllisesti ristiin alakohtien välillä, mikä myöskin alensi vastauksen SOLO-luokkaa.

Vastauksen kieliasuun ja kirjoitusvirheisiin emme luokittelussa puuttuneet enempää kuin mitä SOLO-taksonomian kuvauksessa on määritelty (vrt. Biggs \& Collis, 1982; Biggs \& Tang, 2011). Jos kirjoitusvirheet olennaisesti häiritsivät vastauksen luettavuutta, nähtiin se vastauksen luokittelua alentavana tekijänä. Päätöksemme johtuu siitä, että on havaittu, että esimerkiksi maahanmuuttajataustaisilla tai muuten huonosti suomea osaavilla opiskelijoilla voi olla haasteita tuoda osaamistaan esille kirjoittaessaan koetilanteessa muulla kuin äidinkielellään (Muukkonen, 2017; 2018; 2019). Tämä on Muukkosen mukaan haaste erityisesti maantieteen kaltaisessa oppiaineessa, joka perustuu oppiaineelle ominaisen kielen käyttämiseen ja oppiainesidonnaisiin käsitteisiin.

\section{Esimerkkivastausten luonti}

Seuraavaksi jokaiselle SOLO-taksonomian tasolle luotiin rekonstruktiot tyypillisistä kunkin tason vastauksesta tulosten havainnollistamiseksi. Rekonstruoinneissa pyrittiin jäljittelemään vastausten kirjoitusasuja alkuperäisten muotojen mukaisesti. Vastaukset rekonstruoitiin, koska Ylioppilaskokeen vastaukset ovat salassa pidettävää aineistoa, eikä niitä ole lupa julkaista suoraan sellaisenaan. 


\section{Sisällönanalyysi}

Lopulta vastauksista valittiin satunnaisotannalla osajoukot $\left(n_{\mathrm{t}}=70\right.$ ja $\mathrm{n}_{\mathrm{t} 6}=70$ ), joita analysoitiin laadullisen sisällönanalyysin avulla. Aineisto käytiin läpi ja sieltä eriteltiin ja tunnistettiin vastausten sisältöjen ominaispiirteet ja toistuvuudet. Sovelsimme teorialähtöistä eli deduktiivista sisällönanalyysiä (Elo \& Kyngäs, 2007), koska aiemmin luotu SOLOtaksonomian mukainen luokittelu on antanut vastauksista ennakkotietoa. Lisäksi sisällönanalyysin tukena toimi Ylioppilastutkintolautakunnan (2020a) julkaisemat hyvän vastauksen piirteet.

\section{Tutkimustulosten luotettavuus ja pätevyys}

Laadullisessa tutkimuksessa on aina tärkeää arvioida aineistojen ja analyysien luotettavuutta sekä tulosten pätevyyttä. Tässä tutkimuksessa olemme pyrkineet edistämään näitä triangulaation idean mukaisesti eli olemme käyttäneet erilaisia aineistoja ja menetelmiä. Olemme muun muassa tarkastelleet sekä ylioppilaskokeiden kysymyksiä että niiden vastauksia. Lisäksi tarkastelimme kahta eri kysymystä eri vuosilta. Toisaalta aineisto on tutkimuksessamme edustava otos tutkittavasta joukosta eli ylioppilaskokeisiin osallistuneista lukio-opiskelijoista, koska ylioppilaskoe on valtakunnallinen koe. Kun vertaa tutkimuksemme toteutusta Elon ja muiden (2014, s. 3) luomaan listaukseen laadullisen tutkimuksen luotettavuuden ja pätevyyden tarkastelusta tutkimuksen eri vaiheissa, on otantastrategiamme tältä osin siis luotettava. Toki emme voi olla varmoja, ovatko näihin kysymyksiin vastanneet opiskelijat edustava otos kaikista kokeeseen osallistuneista. Opiskelijat saavat valita mihin kysymyksiin he kokeessa vastaavat. Maantieteen opettajien keskuudessa on yleisesti tunnistettua se, että parhaimmat opiskelijat ovat laskelmoivia ja he vastaavat niihin kysymyksiin, joista kokevat saavansa korkeimmalla todennäköisyydellä korkean pistemäärän. Toisaalta heikoimmat opiskelijat saattavat vastata kysymyksiin, joihin näyttäisi pystyvän vastaamaan yleistietämyksellä, mutta heidän vastauksensa saattaa kuitenkin jäädä pintapuoliseksi ja heikoksi. Tulosten pätevyyttä olisi kenties lisännyt useampien taloudellista kestävää kehitystä käsittelevien kysymysten ja niiden vastausten tarkastelu. Tällöin olisi tullut kattavampi kuva taloudelliseen kestävään kehitykseen liittyvästä opiskelijoiden osaamisesta.

Näemme, että Ylioppilastutkintolautakunnalta saamamme aineisto eli 200 vastausta kumpaankin tutkittavaan kysymykseen oli riittävän laaja tutkimustamme varten, koska SOLO-taksonomian mukaisessa tarkastelussa ja esimerkkivastausten luomisessa tuloksemme saturoituvat merkittävästi ennen 120 läpikäydyn vastauksen kohtaa. Koska tavoitteenamme oli tarkastella Bloomin taksonomian ja SOLO-taksonomian soveltuvuutta ylioppilaskokeen kysymysten ja vastausten luokitteluun, oli sisältöjen analyysi tältä osin luotettava (vrt. Elo ym., 2014, s. 3). Yksittäisen vastauksen luokittelun onnistumista SOLO-taksonomiaan pyrittiin varmistamaan sillä, että vastaukset luettiin läpi kolme kertaa. Viimeisellä lukukerralla luokittelu tarkistettiin. Tämän analyysivaiheen luotettavuutta olisi voinut kehittää, jos useampi tutkija olisi lukenut vastaukset, ja näin varmistanut luokittelun luotettavuuden. Vastausten sisällönanalyysissä puolestaan tulokset saturoituivat merkittävästi ennen 70 läpikäydyn vastauksen kohtaa. Yksittäisiä vääriä vastauksia tai väärinymmärryksiä on saattanut jäädä havaitsematta, mutta oikeista ja hyvän vastauksen piirteissä vaadituista 
sisällöistä otantamme antaa luotettavan kuvan. Elo ja Kyngäs (2007, s. 112) ovat pohtineet, että laadullisen analyysin luotettavuutta ja läpinäkyvyyttä lisäävät todelliset ja aidot viittaukset ja lainaukset. Emme kuitenkaan voi julkaista tässä tutkimuksessa todellisia ja aitoja esimerkkejä vastauksista, koska ylioppilaskokeiden vastaukset ovat salassa pidettävää aineistoa. Tämän takia esitämme tuloksissamme rekonstruoidut tyypilliset esimerkkivastaukset eri ajattelun taidon tasoilta (liitteet 1-2). Rekonstruoiduilla tyypillisillä vastauksilla vastaamme siihen Elon ja Kyngäksen (2007, s. 112) mainitsemaan laadullisen tutkimuksen edellytykseen, että alkuperäisen aineiston ja tulosten välille täytyy esittää yhteys tutkimuksen luotettavuuden lisäämiseksi.

\section{Tulokset ja keskustelu}

\section{Koekysymykset ja Bloomin taksonomia}

Analysoimamme taloudellista kestävää kehitystä käsittelevät kysymykset edellyttivät vastaajilta fakta-, käsite- ja menetelmätietoutta (taulukko 4). Faktatietoa edellytettiin molempien koekysymysten ensimmäisissä kohdissa. Molempien tehtävänannot ohjasivat opiskelijaa selittämään annetut termit ilman viittausta esimerkiksi niihin liittyvien teorioiden avaamiseen. Muut tehtävänannot edellyttivät joko kokonaan tai osittain käsitetietoa. Käsitetieto edellyttää termien hallintaa sekä tiedon peruselementtien välisten yhteyksien tunnistamista ja niiden merkitystä osana laajempaa kokonaiskuvaa (Aksela ym., 2012, s. 15). Tehtävässä 7.3 pyydettiin kuvailemaan kahvin tuotannon alueellisia piirteitä sekä pohtimaan syitä kahvin tuotannon ja kulutuksen alueellisiin eroihin. Tehtävänanto 7.4 taas edellytti osaamista ja tietoa reilusta kaupasta ja sen merkityksestä eri konteksteissa, tehtävänannon tapauksessa merkitystä kahvin viljelijöille, kauppiaille sekä kuluttajille. Tehtävänannossa 6.2 puolestaan pyydettiin selvittämään, mihin hiekkaa tarvitaan ja mitkä seikat vaikuttavat hiekan kulutukseen. Viimeinen tehtävänanto 6.3 vaati kokelaalta osaamista ja ymmärtämistä hiekan käytön teoriasta ja hiekan merkityksestä eri tasoilla sekä taloudellisesta, yhteiskunnallisesta ja ympäristöongelmien kannalta tarkasteltuna. Lisäksi pyydettiin pohtimaan keinoja ongelmien ratkaisemiseksi. Kaikissa käsitetiedon tehtävissä vaadittiin siis perustietoa, jota kyetään soveltamaan ja ymmärtämään eri konteksteissa laajemmin tarkasteltuna. Tehtävänanto 7.3 edusti käsitetiedon lisäksi myös menetelmätietoa, koska siinä pyydettiin tarkastelemaan annettuja karttoja sekä opiskelijan itsensä laatimaa diagrammia ja tekemään niistä maantieteellisesti relevantteja päätelmiä kahvin tuotannosta ja sen kulutuksen alueellisista piirteistä maapallolla.

Vaadittavien ajattelun taidon tasojen tarkastelussa havaittiin neljäntyyppisiä tehtävänantoja. Molempien kysymysten alakohdat edellyttävät joko ymmärtämistä, soveltamista, analysointia tai arvioimista (taulukko 4). Ymmärtämisen tasolle sijoittuivat tehtävänannot 7.1 ja 6.1 , ja niissä vaadittiin tiivistämistä ja perustelemista termien määrittelyn muodossa. Ymmärtäminen edellyttääkin merkitysten muodostamista annetun tiedon pohjalta (Anderson \& Krathwohl, 2001, s. 31). Tämän tason tehtävät ohjaavat opiskelijaa aiemmin opitun asian muistamiseen ja mieleen palauttamiseen sekä tämän tiedon hyödyntämiseen vastauksessa. Tehtävän- 
annossa 6.1 edellytettiin myös luokittelua ja päättelyä, mitkä ovat myös tunnusomaisia ymmärtämisen tasolla. Tasolle 5 arviointi sijoittuivat viimeiset tehtävänannot, joissa muun muassa pyydetään pohtimaan reilun kaupan vaikutusta eri tekijöiden välillä (7.4) ja pohtimaan keinoja hiekan käytön ongelmien ratkaisemiseksi (6.4). Molemmat tehtävänannot edellyttivät aiempaa tietämystä, sen erittelyä ja olennaisten asioiden poimimista. Tehtävänannoissa edellytettiin annettujen ilmiöiden ja termien tarkastelua eri konteksteissa ja kullekin tekijälle ominaisten piirteiden tunnistamista. Lisäksi edellytettiin ilmiön laajempaa arviointia monista eri näkökulmista ja vastauksen hyvää perustelua. Opiskelijan tuli myös osata tunnistaa ja arvioida sopivat ratkaisuehdotukset ennalta opitun perusteella niin, että ne sopivat juuri annettuihin konteksteihin.

Taulukko 4. Ylioppilaskokeiden taloudellista kestävää kehitystä käsittelevien kysymysten edellyttämät tiedon tasot sekä ajattelun taidon tasot Bloomin taksonomian mukaan. Kysymyksen korkein edellytetty taso on lihavoitu.

\begin{tabular}{|l|l|l|}
\hline $\begin{array}{l}\text { Syksy 2018, kysymys 7: Kahvi ja } \\
\text { globalisaatio }\end{array}$ & Tiedon taso & $\begin{array}{l}\text { Edellytetyt ajattelun taidon } \\
\text { tasot ( kognitiiviset prosessit) }\end{array}$ \\
\hline $\begin{array}{l}\text { 7.1 Määrittele käsitteet globalisaatio ja ra- } \\
\text { hakasvi. (6 p.) }\end{array}$ & Faktatieto & Taso 2: Ymmärtäminen \\
\hline $\begin{array}{l}\text { 7.3 Tarkastele karttoja (aineistot 7.B ja 7.C) } \\
\text { ja laatimaasi diagrammia. Kuvaile niiden } \\
\text { perusteella kahvin tuotannon ja kulutuksen } \\
\text { alueellisia piirteitä maapallolla. / Pohdi } \\
\text { syitä kahvin tuotannon ja kulutuksen alu- } \\
\text { eellisiin eroihin. (10 p.) }\end{array}$ & $\begin{array}{l}\text { Käsitetieto / } \\
\text { tieto }\end{array}$ & $\begin{array}{l}\text { Taso 2: Ymmärtäminen / } \\
\text { Taso 3: Soveltaminen }\end{array}$ \\
\hline $\begin{array}{l}\text { 7.4 Pohdi, miten reilu kauppa vaikuttaa } \\
\text { kahvin viljelijöihin, kauppiaisiin ja kulutta- } \\
\text { jiin. (8 p.) }\end{array}$ & Käsitetieto & Taso 5: Arviointi \\
\hline $\begin{array}{l}\text { Kevät 2019, kysymys 6: Hiekka ehtyvänä } \\
\text { luonnonvarana }\end{array}$ & & Taso 2: Ymmärtäminen \\
\hline $\begin{array}{l}\text { 6.1 Mitä tarkoitetaan kivennäismaalajeilla } \\
\text { ja miten niitä luokitellaan? (4 p.) }\end{array}$ & Faktatieto \\
\hline $\begin{array}{l}\text { 6.2 Mihin hiekkaa tarvitaan, ja mitkä seikat } \\
\text { vaikuttavat hiekan kulutukseen? (12 p.) }\end{array}$ & Käsitetieto & Taso 4: Analysointi \\
\hline $\begin{array}{l}\text { 6.3 Mitä taloudellisia, yhteiskunnallisia ja } \\
\text { ympäristöongelmia hiekan käyttöön luon- } \\
\text { nonvarana liittyy? / Pohdi myös keinoja on- } \\
\text { gelmien ratkaisemiseksi. (14 p.) }\end{array}$ & Käsitetieto & $\begin{array}{l}\text { Taso 4: Analysointi / } \\
\text { Taso 5: Arviointi (*) }\end{array}$ \\
\hline
\end{tabular}

Yhtään tehtävänantoa ei luokiteltu tasolle 6 luoda. Tehtävänannot olivat siis melko strukturoituja, eikä yhdessäkään kysymyksessä pyydetty kehittämään, suunnittelemaan tai tuottamaan mitään uutta tai uudenlaista mallia, prosessia tai muuta vastaavaa (vrt. Anderson \& Krathwohl, 2001, s. 31). Tämä havainto on samansuuntainen kuin maantieteilijä Minttu Haapasen (2018) geomediaan liittyvien ylioppilaskoekysymysten tutkimuksen tulokset. Korkeimman kategorian tehtävänantoja ei juuri maantieteen ylioppilaskokeissa tavata. Toisaalta kemian ylioppilaskokeita käsittelevässä tutkimuksessa esseevastaukset on luokiteltu suoraan tasolle 6 (Aksela ym., 2012; Tikkanen, 2010). Maantieteen koekysymykset ovat kuitenkin kemian kysymyksiin verrattuna enemmän vapaata ajattelua vaativia, minkä vuoksi niissä usein edellytetään useasta eri lähteestä kerättyjä 
tietoja ja niiden yhdistelemistä esseemuotoon. Tämän vuoksi tässä tutkimuksessa esseevastaukset eivät suoraan sijoitu 6. tasolle. Tässä on nähtävissä ero kahden erityyppisen luonnontieteen välillä niin koekysymysten piirteissä kuin niihin vastaamisen perinteissä. Tulokset eivät siis ole suoraan verrattavissa toiseen oppiaineeseen.

Vaikka molempien analysoitujen koekysymysten tehtävänannot oli jaettu alakohtiin, edellyttivät ne korkeimmillaan vain arvioinnin taitoja. Alakohdat alkoivat molemmissa kysymyksissä ymmärtämisen taitojen testaamisella, jatkuivat tehtävänannosta riippuen joko soveltamiseen tai analysointiin ja ylsivät viimeisen alakohdan arviointitehtävään. Vaativuustaso eteni siis konkreettisesta abstraktimpaan, mikä on linjassa Bloomin taksonomian periaatteen kanssa (vrt. Anderson \& Krathwohl, 2001). Tiedon tasoiltaan tehtävien hajonta oli laajaa, koska tehtävänannot edustivat sekä fakta-, käsite- ja menetelmätietoutta. Koska ylioppilaskokeiden tavoitteisiin on kirjattu maantieteellisen ajattelun, lukutaidon ja lähestymistavan sekä käsitteiden osaaminen ja ymmärtäminen (Ylioppilastutkintolautakunta, 2018), tukee tällainen monipuolinen tiedon tasojen testaaminen tavoitteiden mukaista arviointia.

\section{Esseevastausten ajattelun taitojen tasot}

Kokelaiden vastauksista pystyi helposti tunnistamaan heikot ja muita ansiokkaammat vastaukset. Keskimmäisten tasojen välillä raja oli usein häilyvämpi, ja siksi SOLO-taksonomian päätasojen välisten välitasojen käyttö oli perusteltua. Vastauksia pidettiin ansiokkaina silloin, kun niissä oli oivallettu laajempi konteksti ja esimerkiksi ensimmäisen alakohdan käsitteistö ohjasi kokelasta oikeaan suuntaan. Vain harvoin vastauksissa oli oivallettu käyttää aiemmin annettuja käsitteitä myöhemmin vastauksissa.

Molempien tehtävänantojen vastausten ajattelutaitojen jakautuminen SOLO-luokkiin oli varsin yhdenmukaista. Tämä saattaa johtua siitä, että tehtävänannot olivat saman tyyppisiä: ne olivat kokeen osan III kysymyksiä ja edellyttivät siksi saman tasoista osaamista. Analyysissamme opiskelija sai vastauksiinsa yhden SOLO-taksonomian tason kaikki kysymyksen osatehtävät huomioiden. Molempien taloudellista kestävää kehitystä käsittelevien koekysymysten vastauksissa oli nähtävissä lähes kaikkia SOLO-taksonomian tasoja (kuviot 1-2). Syksyn 2018 kysymyksessä 7 kahvin tuotannosta esiintyi eniten tason 2A (mediaani ja moodi) mukaisia vastauksia. Kevään 2019 kysymyksessä 6 hiekasta ehtyvänä luonnonvarana puolestaan eniten esiintyi tasaisemmin sekä tason $2 \mathrm{~A}$ (mediaani) että tason 3 (moodi) mukaisia vastauksia eli jakauman huippu on korkeammalla SOLO-taksonomian tasolla kuin kysymyksessä 7 kahvista. Kun SOLO-taksonomian ajattelun taidon tasot muutetaan uudeksi johdetuksi lineaariseksi välimatka-asteikolliseksi muuttujaksi (vaihteluväli 1,0-5,0), jolle voi laskea keskiarvon, on vastausten keskiarvot kysymyksissä 7 (syksy 2018) ja 6 (syksy 2019) vastaavasti 2,640 ja 2,661 eli kuitenkin varsin lähellä toisiaan. Molempien kysymysten vastausten keskiarvot ovat yhden otoksen t-testin perusteella keskimäärin vain hieman, mutta kuitenkin tilastollisesti merkitsevästi (vastaavasti testisuureet $t$ olivat 2,328 ja 2,336 sekä p-arvot 0,022 ja 0,021 ) ansiokkaampia vastauksia kuin SOLO-taksonomian taso $2 \mathrm{~A}$ (eli uuden muuttujan arvo 2,50). Taso 2A:han oli aineiston mediaani (ks. kuviot 1-2). 
Vaikka näiden kahden kysymyksen vastausten jakaumissa silmämääräisesti näkyykin hivenen eroa (kuviot 1-2), keskimäärin (mediaani) opiskelijoiden vastauksissa ei ollut Mann Whitneyn U-testin perusteella tilastollisesti merkitsevää eroa (testisuure $z$ oli 0,123 ja p-arvo 0,904). Molempien kysymysten vastaukset olivat siis keskimäärin hyvin lähellä toisiaan.

Kysymyksessä 6 hiekasta ehtyvänä luonnonvarana tehtävänannossa oli tarjolla runsaasti aineistoa johdattelemassa aiheeseen, mikä mahdollisesti auttoi keskinkertaisia opiskelijoita vastaamaan muuten haastavaan kysymykseen hiekasta, jota ei ole oppitunneilla juurikaan käsitelty ehtyvänä luonnonvarana. Tämä saattoi nostaa muuten haastavamman tehtävänannon vastausten ajattelun taidon tasoja SOLO-taksonomiassa. Vastauksia luokiteltaessa otettiin kuitenkin huomioon vastaajan oman ajattelun näkyminen. Jos vastauksessa oli lähinnä referoitu aineistoja, se laski vastauksen SOLO-taksonomian mukaista tasoa. Lisäksi molempien kysymysten vastauksissa oli havaittavissa varsin paljon epäjohdonmukaista kieltä ja kirjoitusvirheitä. Nämä tekijät laskivat vastauksen SOLO-taksonomian tasoa useimmiten vain korkeampien ajattelun taidon SOLO-tasoilla, koska ne edellyttävät vastauksilta hyvää luettavuutta ja virheetöntä maantieteellistä tekstiä. Myös hyvän vastauksen piirteissä mainitaan täsmällinen kieli (Ylioppilastutkintolautakunta, 2020). Haapanen (2018) on havainnut maantieteen ylioppilaskokeen esseevastauksissa, että usein epäjohdonmukainen kieli ja kirjoitusvirheet johtuvat osaamattomuudesta johtuvasta aiheen kiertelystä silloin, kun opiskelijalla ei ollut aiheesta täyttä varmuutta. Tämän tunnistaminen voi usein olla kuitenkin haastavaa, koska myös heikko suomen kielen osaaminen muun muassa maahanmuuttajataustaisilla opiskelijoilla näkyy epäjohdonmukaisena kielenä ja kirjoitusvirheinä (vrt. Muukkonen 2017; 2018; 2019). Tämän takia näemme SOLO-taksonomian heikkoutena sen, että se olettaa opiskelijoiden olevan kielellisiltä valmiuksiltaan samalla tasolla, eikä se ota huomioon esimerkiksi maahanmuuttajataustaisuudesta johtuvaa kielellistä takamatkaa verrattuna niihin, jotka saavat vastata kokeeseen omalla äidinkielellään.

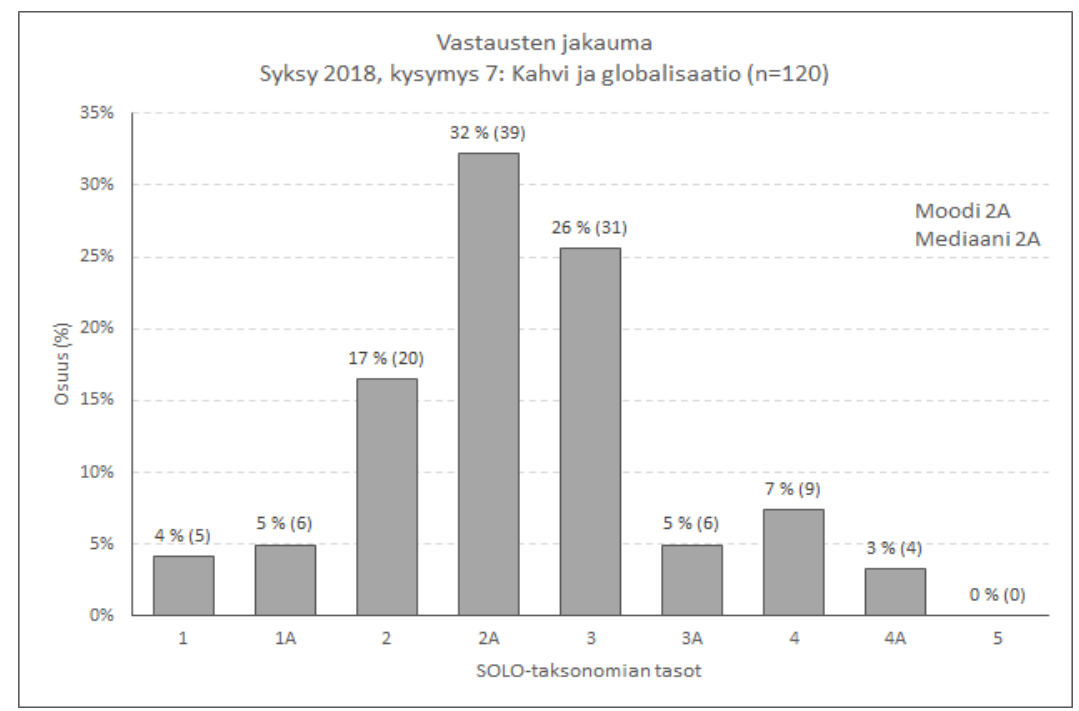

Kuvio 1. Vastausten jakauma $(n=120)$ SOLO-taksonomian mukaan luokiteltuna syksyn 2018 maantieteen ylioppilaskokeen taloudellista kestävää kehitystä käsittelevässä kysymyksessä 7 Kahvi ja globalisaatio. 


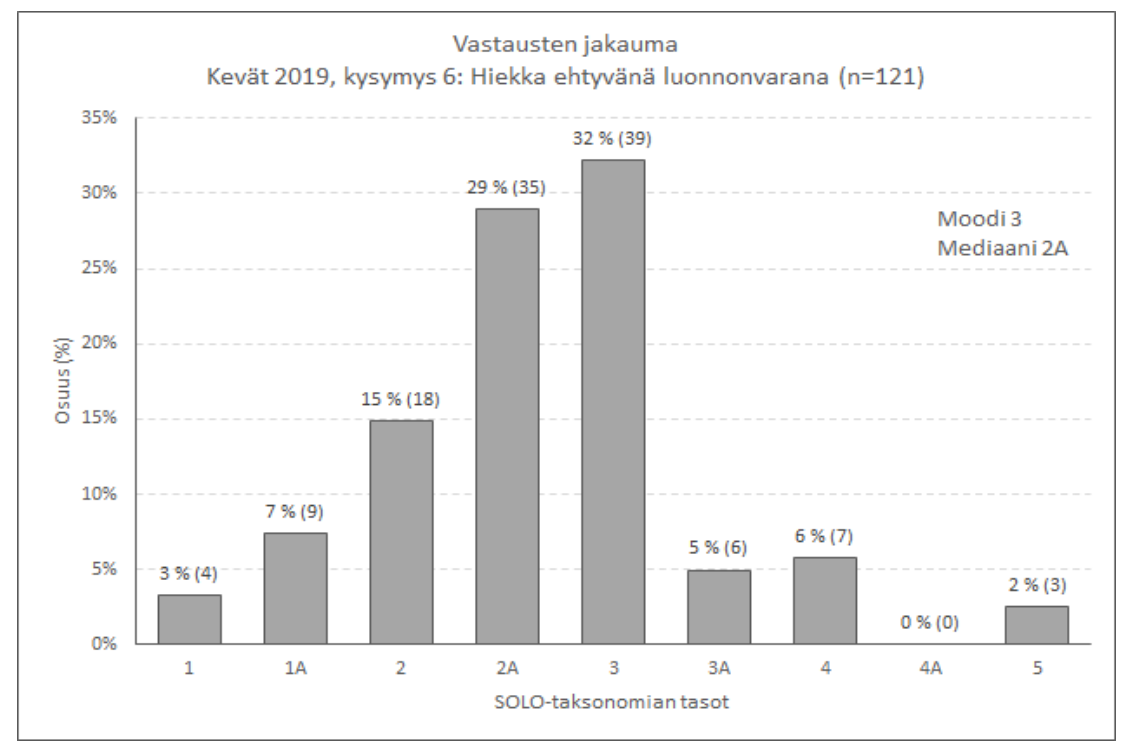

Kuvio 2. Vastausten jakauma $(n=121)$ SOLO-taksonomian mukaan luokiteltuna kevään 2019 kevään maantieteen ylioppilaskokeen taloudellista kestävää kehitystä käsittelevässä kysymyksessä 6 Hiekka ehtyvänä luonnonvarana.

Liitteissä 1 ja 2 esitämme aineistosta rekonstruoimamme tyypilliset vastaukset. SOLO-taksonomian tason 1 esirakenteisissa vastauksissa on paljon epäolennaisuuksia, eikä vastaus etene loogisesti. Esimerkiksi kevään 2019 kysymyksen 6 vastauksissa saatettiin selittää kivennäismaalajin määritelmä väärin tai hiekasta aiheutuvat ongelmat on selitetty epäjohdonmukaisesti tai asiaan kuulumattomalla tavalla. Osa kokelaista ei ole osannut vastata ollenkaan tai vastaus on täysin väärin. Vastauksissa on saatettu myös paneutua liikaa vain yhteen, usein väärään, näkökulmaan tai vaihtoehtoisesti siinä on avattu useita, hieman epäolennaisia tekijöitä. Esimerkiksi syksyn 2018 kysymyksessä 7 saatettiin selittää kahvin kulutuksen syitä tunteeseen pohjautuvalla tiedolla, mutta unohtaa mainita tietoon perustuvia huomioita tai alueellisia tekijöitä tai huomioita ei ole osattu perustella muilla keinoilla. Samoja termejä on toistettu vastauksessa usein, mikä kertoo kokelaan epävarmuudesta.

SOLO-taksonomian tason 1A esirakenteisen siirtymän vastauksissa on lueteltu joitain oikeita huomioita tai yksi laajempi kokonaisuus, mutta ne on vain harvoin perusteltu asiaan kuuluvalla tavalla. Vastauksissa on myös havaittavissa virheellisiä perusteluja tai liikaa yksittäisiä huomioita, joita ei ole kytketty laajempaan kokonaisuuteen tai ne eivät sovi siihen lainkaan. Samaa asiaa on selitetty toistuvasti uudelleen ja aihe kiertää kehää. Esimerkiksi kahvin tuotannollisia syitä on perusteltu kysymyksessä 7 useampaan kertaan paneutumatta lainkaan kulutuksellisiin syihin. Perustelut ovat usein myös varsin pinnallisia, kuten esimerkiksi kahvin piristävän vaikutuksen korostaminen pohjoismaalaisten kulutustottumuksissa.

SOLO-taksonomian tason 2 yksinkertaisessa vastauksissa on edellisen tason 1A pelkkien yksittäisten huomioiden lisäksi enemmän oikeita huomioita, mutta ne on lueteltu satunnaisessa järjestyksessä vastauksessa, eikä jäsentelyä ole nähtävissä. Vastauksissa on löydettävissä yksi laajempaan kuvaan sopiva näkökulma kuten hiekan pimeä kauppa kysymyksessä 
6 tai varallisuuserojen merkitys kahvin tuottaja- ja kuluttajamaiden välillä kysymyksessä 7. Vastauksissa ei kuitenkaan vielä osoiteta aiheen laajempaa hallintaa osana kokonaisuutta. Usein vastaus on luettelomainen koostuen pääosin perustelemattomista väitteistä. Aihetta on kuitenkin tarkasteltu alueellisesta näkökulmasta enemmän kuin 1- ja 1A-luokkien vastauksissa ja paikannimistöä on käytetty aikaisempaa enemmän.

SOLO-taksonomian tason $2 \mathrm{~A}$ yksinkertaisen siirtymän vastauksissa on esitetty aikaisempaa enemmän oikeita, laajempaankin kokonaisuuteen liittyviä huomioita. Vastauksissa on kuitenkin nojattu vahvasti aineistoon, eikä omalle ajattelulle ole annettu juurikaan tilaa. Vastaukset etenevät edelleen epäjohdonmukaisesti luettelomaisena kokonaisuutena, eikä huomioita ole aina täysin perusteltu. Vastaukset ovat muutenkin pinnallisia, vaikka laajempaan kontekstiin liittyviä aihealueita on jo osattu huomioida vastauksissa; esimerkiksi kevään 2019 kysymyksen 6 vastauksissa on mainittu esimerkiksi ilmastonmuutos, pimeä kauppa ja maailman eriarvoiset alueet ja niiden merkitys hiekan kulutuksessa ja ongelmien esiintymisessä.

SOLO-taksonomian tason 3 monirakenteisissa vastauksissa on paljon hyviä huomioita, mutta ne on usein perusteltu vain osittain. Vastauksissa on jo havaittavissa oman ajattelun näkymistä aineiston tarkastelun rinnalla. Vasta tässä SOLO-taksonomian luokassa näkyy sekä karttojen että diagrammin aineistot osana aiheen käsittelyä. Vastaukset etenevät loogisesti, mutta syvempiä päätelmiä aiheeseen liittyen ei vielä osata tehdä. Aihealueita ei kytketä toisiinsa, eikä esimerkkejä juuri esiinny. Vaikka vastauksissa on osattu huomioida jo monia erilaisia näkökulmia aiheeseen liittyen, syy-seuraussuhteita ei vielä ole tarkasteltu, vaan vastaus etenee luettelomaisesti.

SOLO-taksonomian tason 3A monirakenteisen siirtymän vastauksissa syy-seuraussuhteita havaitaan asiakokonaisuuksien välillä ja niitä osataan jo sivuta vastauksissa. Luettelomaisuus on kuitenkin edelleen ominaista tämän tason vastauksille. Vastauksissa näkyy kuitenkin johdonmukaisempi käsittelytapa ja sen rakenne hahmottuu aikaisempia luokkia vahvemmin. Kysymyksessä 7 on kahvin tuotannon ja kulutuksen alueellisia eroja osattu jo tulkita aineiston pohjalta varsin laajasti ja niiden välisiä eroja on pystytty tuomaan esiin onnistuneesti. Vastausten luettavuus on jo varsin hyvää, mikä näkyy esimerkiksi kevään 2019 kysymyksessä 6, kun hiekan kulutuksen syyt hahmottuvat entistä laajemmassa kontekstissa ja ongelmia on osattu tulkita useista eri näkökulmista. Aiheisiin ei ole kuitenkaan syvennytty enempää, vaikka ne on tunnistettu vastauksissa.

SOLO-taksonomian tason 4 tyypillinen relationaalinen vastaus on looginen ja sisältää paljon hyviä huomioita esimerkiksi hiekan käytöstä, kulutuksen syistä sekä ongelmista ja niiden ratkaisumalleista. Aineistoon on kuitenkin nojattu edelleen vahvasti, vaikka oma ajattelu näkyykin alempia luokkia vahvemmin vastauksissa. Aineistoja on vertailtu hyvin toisiinsa ja niistä on nostettu esiin huomioita, jotka ovat merkityksellisiä kokonaisuuden kannalta; esimerkiksi kysymyksessä 7 Brasilian sekä runsas kahvin tuottaminen että korkea kulutus. Asioiden toisiinsa kytkeminen ja syy-seuraussuhteiden tarkastelu näkyvät vastauksissa, mutta vielä vain osittain. Vastauksissa ei ole kytketty aihealuetta laajempaan näkökulmaan, vaan esimerkiksi kysymyksessä 6 hiekkaa on tarkasteltu 
raaka-aineena vielä yksipuolisella tasolla. Maantieteellisiä termejä ei käytetä täysin virheettömästi, eikä aineistoon viittaaminen ole aina korrektia.

SOLO-taksonomian tason 4A relationaalisen siirtymän vastauksia ei havaittu hiekkaa käsittelevän kysymyksen vastauksen otoksessa (vrt. liite 2 ja kuvio 2). Kahvia käsittelevän kysymyksen 7 vastauksissa oli jo paljon taksonomian luokan 5 elementtejä kuten abstraktimpaa ajattelua sekä syvällisempää syy-seuraussuhteiden tarkastelua (liite 1). Vastaus ei kuitenkaan vielä esittele vallitsevia teemoja osana laajempaa kontekstia tai luo siitä yleistystä. Globalisaation ja rahakasvin termit on selitetty monipuolisesti ja niitä on tarkasteltu monista eri näkökulmista. Samoin siirtomaa-ajan merkitys osana kahvin tuottamista ja kuluttamista on osattu huomioida osana tämän luokan vastauksia entistä useammin.

SOLO-taksonomian tason 5 laajoja abstrakteja vastauksia ei havaittu kahvia käsittelevän kysymyksen vastausten otoksessa (ks. liite 1 ja kuvio 1). Hiekkaa käsittelevät tason 5 vastaukset koostavat erinomaisesti olennaiset aiheeseen ja laajempaan ilmiöön liittyvät tekijät perusteluineen ja kytkevät ne toisiinsa (liite 2). Vastauksissa tutkitaan syy-seuraussuhteita ja aiheet etenevät johdonmukaisesti ja loogisesti. Hiekkaa on käsitelty yleisellä tasolla luonnonvarana ja vastaus on kytketty laajempaan kontekstiin ilmiönä onnistuneesti. Vastaukset on eritelty hyvin ja ristiriidat ja johtopäätökset on esitetty selkeästi. Vastauksissa on käsitelty asiaa alueellisesta ja globaalista näkökulmasta, eikä teksti ole luettelomainen. Vastauksissa on myös käsitelty montaa näkökulmaa ja teksti on kirjoitettu helposti luettavaan ja miellyttävään muotoon.

Vastauksista huomasi usein, että kysymyksiin oli vastattu liittämättä vastausta saman kysymyksen muihin osatehtäviin. Tämän takia osatehtävien vastaukset olivat irrallisia toisistaan, ja siksi niiden luokittelu esseevastauksina SOLO-taksonomian mukaan oli haastavaa. Mitä enemmän vastauksissa ilmeni ymmärrys osatehtävien liittymisestä toisiinsa, sitä enemmän niiden sisällöt oli osattu huomioida vastaamisessa; esimerkiksi kahvin tuotannon ja kulutuksen kysymyksessä oli käytetty sekä globalisaation ja rahakasvin termejä (7.1) ja kahvinviljelyn alueellisuutta (7.3) hyödyksi reilua kauppaa käsittelevässä viimeisessä osatehtävässä (7.4). Tällaiset tekijät toki nostivat vastauksen SOLO-taksonomian mukaista ajattelun taidon tasoa. Tämä saattaa olla myös yhtenä syynä sille, että niin moni vastauksista sijoittui SOLO-taksonomian keskivaiheille. Haapanen (2018) toimi omassa tutkimuksessaan eri tavalla luokitellessaan maantieteen ylioppilaskokeen esseevastaukset SOLO-taksonomian tasoihin osatehtävittäin. Tämä valinta ei olisi toiminut meidän tutkimukseemme valittujen tehtävänantojen kohdalla, koska molempien kysymysten ensimmäiset osatehtävät käsittelivät vain käsitteiden selitystä, ja vastauksia ei olisi voinut sellaisenaan luokitella SOLO-taksonomian avulla. Tästäkin huolimatta SOLO-taksonomia toimi tutkimuksessamme hyvin, kun SOLO-taksonomia oli ensin muokattu vastaamaan kriteeristöltään maantieteen esseevastausten tarkastelua (ks. taulukko 3). 


\section{Bloomin taksonomian ja SOLO-taksonomian keskinäinen vastaavuus}

Kahviaiheisen kysymyksen tehtävänanto edellytti opiskelijalta ymmärtämisen, soveltamisen ja arvioimisen taitoja, kun taas hiekka-aiheisen kysymyksen tehtävänanto ymmärtämisen, analysoimisen ja arvioinnin taitoja. Molemmissa taloudellista kestävää kehitystä käsittelevissä kysymyksissä korkein vaadittava Bloomin taksonomian mukainen taso oli 5 arviointi (taulukko 4). Hiekka-aiheisen kysymyksen tehtävänannon vastaukset edustivat eniten SOLO-taksonomian tasoa $2 \mathrm{~A}$ eli yksinkertaisen siirtymän vastausta sekä tasoa 3 eli monirakenteisen vastauksen tasoa, sillä mediaanivastaus osui tasolle $2 \mathrm{~A}$ ja aineiston moodi oli taso 3 (kuvio 2). Nämä keskiluvut kertovat millaisiin ajattelun taidon tasoihin opiskelijat keskimäärin ylsivät vastauksissaan. Vastaukset edustavat pääosin keskitasoa, kuten on odotettuakin. Tulos on looginen, koska korkeimpiin ajattelun taidon tasoihin vastauksissaan yltävät vain parhaat opiskelijat ja vastauksilta voi odottaa lähes normaalijakauman mukaista jakaumaa (kuviot 1-2). Myös Fahmy (2018) on havainnut maantieteen ylioppilaskokeiden esseevastauksissa, ja Koskinen (2005) eläinlääketieteellisen tiedekunnan tenttivastauksissa, että vastausten jakauma on SOLO-taksonomian perusteella liki samanlainen kuin meidän tutkimuksemme jakaumat.

Emme kuitenkaan voi olla varmoja, että kysymykseen vastanneet opiskelijat ovat tutkimuksessamme edustava otos koko maantieteen kokeisiin osallistuneesta joukosta. Maantieteen opettajien keskuudessa on yleisesti tunnistettu, että parhaat opiskelijat ovat laskelmoivia, ja he valitsevat kokeesta ne kysymykset, joista arvioivat saavansa korkeimmat pisteet. Lisäksi heikoimmat opiskelijat valitsevat usein kysymyksiä, joihin heidän mielestään näyttäisi pystyvän vastaamaan yleistietämyksellä, mutta sitten vastaus jääkin heikkotasoiseksi. On myös huomioitava, että tarkastellut kaksi koekysymystä ovat maantieteen ylioppilaskokeiden osasta III, joiden kysymyksissä ja tehtävänannoissa edellytetään korkeampia ajattelun taidon tasoja ja tiedon soveltamista. Kokeen osissa I ja II ei edellytetä yhtä korkeita ajattelun taidon tasoja. Näin ollen koko kokeen yhteispisteissä opiskelijoiden suoriutuminen noudattaa lähes normaalijakaumaa (vrt. Ylioppilastutkintolautakunta, 2020b). Emme voineet tarkastella tätä tarkemmin, koska tutkimuslupamme ei kattanut yksittäisten opiskelijoiden saamia pistemääriä tai eri kysymyksiin vastanneiden opiskelijoiden lukumääriä. Toisaalta Fahmy (2018, ss. 59-61) on aiemmin havainnut vastausten SOLO-taksonomian mukaisten ajattelun taidon tasojen ja todellisten koepisteiden välillä tilastollisesti merkitsevän korrelaation. Fahmy (2018) kuitenkin tiivistää, että suoria johtopäätöksiä kokeessa menestymisestä (koe- ja tehtäväpisteet) ei voi tehdä pelkästään SOLO-taksonomian perusteella, koska pisteytyksessä arvioidaan myös osaamisen määrällistä ulottuvuutta. Osatehtäviin jaetut kysymykset ja tehtävänannot aiheuttivat lisäksi haasteita tutkimusaineiston vastausten luokittelemisessa SOLOtaksonomian luokkiin. Mikäli tehtävänanto koostuisi vain yhdestä laajemmasta kysymyskokonaisuudesta, opiskelija vastaisi osaamisensa mukaan niin, että esseevastaus muodostaisi yhden selkeän kokonaisuuden. Toisaalta osatehtäviin pilkotut tehtävänannot antavat jokaiselle opiskelijalle mahdollisuuden vastata edes johonkin, koska tehtävänannot etenevät kysymyksen sisällä usein yksinkertaisemmasta haastavampaan. Lisäksi 
pilkottu tehtävänanto ohjaa opiskelijoita vastaamisessa haluttuun suuntaan ja auttaa jäsentämään vastaamista. Usein opiskelijat ovat kuitenkin vastanneet laajoihin kysymyksiin niin, että lopputuloksena syntyy vastaus, jossa on vastattu yksilökohtaisesti vain osatehtäviin, eikä läheskään aina ole osattu ajatella vastausta laajempana kokonaisuutena.

Tutkimuksemme perusteella tarkastelut taloudellisen kestävän kehityksen osaamista testaavat kysymykset vastasivat hyvin lukio-opetuksen vaatimuksia niin sisällöllisesti kuin vaatimustasoltaan (vrt. Opetushallitus, 2015). Tätä näkemystä tukevat tuloksemme niin Bloomin taksonomian mukaisesta kysymysten edellyttämistä ajattelun taidon tasoista kuin SOLO-taksonomian mukaan luokitelluista esseevastauksista. Lukion opetussuunnitelman perusteiden läpileikkaavina teemoina on mainittu monissa oppiaineissa, että opiskelijan tulee osata tunnistaa, arvioida ja vertailla alueiden riskejä ja niiden herkkyyttä sekä osata analysoida maailman alueiden kehitystä ja sen suuntaa sekä niihin vaikuttavia tekijöitä (Opetushallitus, 2015). Lisäksi lukio-opiskelijan tulisi ymmärtää ympäristö- ja kestävyysongelmien merkitys paikallisella ja maailmanlaajuisella tasolla ja tunnistaa olemassa olevat ratkaisumahdollisuudet. Tutkitut kysymykset testasivat toimivasti myös näitä taitoja. Toisaalta molemmat kysymykset käsittelivät kestävän kehityksen globaaleja ilmiöitä, eikä yllä mainittu paikallistason tarkastelu tullut vastauksissa aina niin selvästi ilmi. Siksi useampien maantieteen ylioppilaskokeen kysymysten tarkastelu olisi voinut lisätä tulostemme kattavuutta ja sitä myöten luotettavuutta. Nyt tarkastelimme vain kahta kysymystä ja niiden vastauksia. Jatkossa voisi tutkia myös useampien oppiaineiden ylioppilaskokeiden kysymyksiä ja niiden vastauksia. Näin saisi kattavamman kuvan siitä, kuinka taloudelliseen kestävään kehitykseen liittyvissä esseevastauksissa eri oppiaineiden kokeissa näkyy opiskelijoiden osaaminen ja ajattelun taidon tasot.

\section{Vastausten sisällöt ja käsitellyt asiat}

Taloudellista kestävää kehitystä käsittelevissä maantieteen ylioppilaskokeen kysymyksissä analysoimme myös vastausten sisältöä kvalitatiivisella sisällönerittelyllä, jotta nähtäisiin mitä opiskelijat osaavat sisällöllisesti taloudelliseen kestävään kehitykseen liittyen. Sekä kahviaiheisen kysymyksen että hiekka-aiheisen kysymyksen vastauksista tarkastelimme molemmista 70 opiskelijan vastausten sisällöt.

Kahviaiheisen kysymyksen vastauksissa jopa 86 prosentissa mainittiin ilmasto-olojen vaikutus kahvinviljelyn ja tuotannon painottumiseen eteläiselle pallonpuoliskolle. Lisäksi liki 79 \% osasi kertoa, että kahvin tuotanto keskittyy kehittyviin maihin päiväntasaajan alueella, kun taas kulutus painottuu pohjoiselle pallonpuoliskolle teollisuusmaihin. Vain 13 prosentissa vastauksista oli oivallettu Brasilian näkyminen aineistoissa sekä suurena tuottajana että kuluttajana sekä Brasilian sisäinen eriarvoisuus. Vain muutamia kertoja vastauksissa mainittiin, että Pohjoismaissa kahvinviljely ei ole järkevää tai taloudellisesti kannattavaa kylmän ilmaston takia (16\%). Noin $47 \%$ opiskelijoista mainitsi, että varakkailla mailla on parhaimmat mahdollisuudet varallisuutensa takia ostaa ja käyttää kahvia nautintoaineena. Toisaalta vain $29 \%$ vastasi, että kehittyvien maiden asukkailla ei ole varaa ostaa ylimääräisiä nautintoaineita kuten kahvia, koska valtaosa tuloista menee välttämättömään ravintoon. Noin 44 
prosentissa vastauksista mainittiin, että kahvilla on kulttuurisia perinteitä etenkin Pohjoismaissa ja Suomessa. Noin 31 \% kokelaista yritti haparoiden pohtia, että kahvi on lämmike, jota juodaan pääosin kylmillä alueilla, eikä se maistu lämpimillä alueilla yhtä hyvin. Kahvin addiktoivaa vaikutusta yritettiin tuoda mukaan maantieteellisesti selittäväksi tekijäksi kolmessa prosentissa vastauksista.

Yhteensä $33 \%$ opiskelijoista pohti, että kehittyvissä maissa työvoima on halpaa ja siksi kahviplantaaseja pidetään yllä niillä alueilla. Liki yhtä moni (29\%) pohti kahvia vientituotteena teollisuusmaihin ja ulkomaankaupan kannattavuutta. Pieni osa opiskelijoista (10\%) pohti myös sitä, että rahakasvien (kuten kahvin) viljelyä on vaikea lopettaa, koska kyseiset valtiot ovat usein hyvin riippuvaisia juuri kyseisestä vientituotteesta. Vastauksissa oivallettiin siis, että taloudellisesti kestämätöntä on se, että valtio on riippuvainen vain yhdestä vientituotteesta. Siirtomaaajan historian merkitys tuotiin esille vain 11 prosentissa vastauksista. Pieni osa vastaajista yritti tuoda vastaukseensa mukaan myös globalisaation vaikutusta innovaatioiden ja kulutustuotteiden levittäjänä (3\%).

Kysyttäessä millaisia vaikutuksia reilulla kaupalla on kahvin viljelijöiden, kauppiaiden sekä kuluttajien näkökulmasta jopa $86 \%$ vastasi, että reilu kauppa helpottaa viljelijöiden pärjäämistä taloudellisesti, koska siinä turvataan asianmukainen hinta kahvinviljelystä. Lisäksi jopa $89 \%$ osasi vastata, että reilun kaupan kahvi on kuluttajalle hieman kalliimpaa kuin normaalisti tuotettu kahvi, mutta tietoisuuden lisääminen eettisesti tuotetusta kauppatavarasta tuo positiivisen mielikuvan kuluttajalle. Noin $47 \%$ opiskelijoista pohti vastauksissaan, että reilun kaupan kahvin tuominen myyntiin maksaa kauppiaallekin normaalia enemmän, mutta liki yhtä moni vastaaja $(51 \%)$ mietti, että reilun kaupan kahvi toisaalta tuo hyvää mainosta yrittäjälle. Noin 37 \% vastasi, että reilu kauppa turvaa viljelijöille paremmat työolot. 17 prosentissa vastauksista mainittiin, että reilu kauppa ehkäisee lapsityövoimaa. Muutamissa vastauksissa yritettiin pohtia reilun kaupan hyötyjä myös ympäristön tilan turvaamisen ja tätä kautta kestävän kehityksen näkökulmasta (7 \%), rikollisuuden vähenemisen kannalta (1 \%) ja alueen työpaikkojen lisääntymisen kannalta (3\%). Toisin sanoen vain harvoissa vastauksissa oli huomioitu kestävän kehityksen ympäristönäkökulmat; toki tehtävänanto ei tähän näkökulmaan suoraan ohjannutkaan.

Hiekka-aiheisen kysymyksen vastauksissa käsiteltiin tehtävänannon mukaisesti sekä hiekan käyttökohteita että kulutukseen liittyviä tekijöitä sekä sen käytöstä juontuvia ongelmia ja niiden ratkaisumahdollisuuksia. Aineiston suuri määrä näkyi vastauksissa, ja vastauksissa esiintyi keskenään samanlaisia piirteitä. Noin 86 prosentissa vastauksista mainittiin, että betoni ja rakentaminen ovat hiekan ensisijaisia käyttökohteita. Tämän lisäksi mainittiin maanrakennukseen liittyviä teemoja kuten esimerkiksi maanpinnan muotoilu hiekalla (21\%), hiekkarantojen muokkaus ja luominen $(31 \%)$ sekä saarien ja uuden maa-alan rakentaminen hiekasta (30 \%). Vain harva osasi mainita hiekoituksen $(9 \%)$ tai hiekan kyvyn suodattaa puhdasta pohjavettä $(10 \%)$. Käyttökohteita ja kulutuksen syitä käsiteltäessä mainittiin kulutukseen liittyvä kysyntä tai tarjonta noin 50 prosentissa vastauksista. Väestönkasvun seurauksena lisääntynyt rakentamisen tarve ja sitä kautta nouseva hiekan kulutus mainittiin noin 29 prosentissa 
vastauksista, kun taas kaupungistuminen mainittiin vain noin 16 prosentissa. Muutamia mainintoja vastauksissa saivat kulutukseen vaikuttavina tekijöinä se, että hiekka halutaan tuoda mahdollisimman läheltä (14\%) sekä valtioiden taloudellinen kehittyminen ja sitä myötä lisääntyvät rakennusmahdollisuudet $(6 \%)$.

Kun vastauksissa käsiteltiin hiekan aiheuttamia ongelmia, eniten vastauksissa mainittiin pimeät hiekkamarkkinat ja laittomat kaivaukset sekä harmaa talous $(74 \%)$. Noin $50 \%$ oli maininnut yleisesti ongelmat talouden ja yhteiskunnan tasolla, koska hiekan uusiutumisnopeus on niin hidas suhteessa sen käyttötahtiin. Ympäristölle aiheutuvista ongelmista useimmin (44\%) mainittiin ekosysteemien tuhoutuminen ja biodiversiteetin köyhtyminen hiekan kaivuun seurauksena. Hiekan kuljetuksesta aiheutuvat päästöt mainittiin noin 29 prosentissa vastauksista ja tästä epäsuorana vaikutuksena ilmastonmuutos noin 19 prosentissa vastauksia. Noin $29 \%$ opiskelijoista mainitsi myös saarien katoamisen ja ruoppauksen ympäristöä kuormittavana tekijänä. Eroosion ja siitä seuraavat ongelmat tuotiin esille noin 20 prosentissa vastauksia.

Ratkaisuehdotuksia hiekan käytön ongelmille ei esitetty yhtä laajasti kuin aikaisempien osatehtävien kohdalla. Useimmiten ratkaisuksi nähtiin rajoitusten ja säädösten tiukentaminen, jotka vähentäisivät hiekan käyttöä sekä laittomuuksia (44\%) - mikä toki osaltaan lisääkin kestävyyttä epäsuorasti. Noin $43 \%$ vastauksista sisälsi pohdintaa, että hiekalle tulisi kehittää jokin korvaava materiaali, mutta tässä tapauksessa ei ollut huomioitu sitä, että korvaavan materiaalin käyttö hiekan sijaan ajaa samassa mittakaavassa myös sen liialliseen käyttöön, ja kestämättömyysvaikutukset ovat jälleen vastassa. Vain muutamia mainintoja $(<11 \%)$ saivat alueiden lisääntyvä eriarvoisuus hiekan käytön seurauksena, yhteiskunnan sisäinen epätasa-arvo sekä konfliktien lisääntyminen. Ratkaisumahdollisuuksina mainittiin muutamia kertoja $(<7 \%)$ riskeistä tiedottamisen ja tietoisuuden lisääminen, muiden luonnonvarojen käyttö vaihtoehtoisina raaka-aineina, rakennuksien kestävyyden parantaminen ja vanhojen rakennusten ja materiaalien kierrätys, rakentamisen vähentäminen sekä hiekan kokonaiskäytön vähentäminen.

Kummankaan kysymyksen vastauksissa ei osattu tuoda esille taloudellisen kestävän kehityksen perimmäistä problematiikkaa eli sitä, että taloudellinen kehitys ei saisi tapahtua ympäristön kustannuksella (vrt. World Commission on Environment and Development, 1987). Vastauksista puuttui myös huomiota voittojen tasaisesta jakautumisesta lähde- ja kohdemaan välillä, mikä myös on keskeistä taloudellisesti kestävässä kehityksessä. Tutkimuksessamme tarkastelimme vain kahta maantieteen ylioppilaskokeen kysymystä ja niiden vastauksia. Useampien kysymysten tarkastelu olisi saattanut tuoda esille laajemmin opiskelijoiden sisällöllistä osaamista taloudellisesti kestävästä kehityksestä. 


\section{Yhteenveto}

Tutkimuksemme ensimmäisenä tavoitteena oli selvittää, millaisia ajattelun taidon tasoja taloudellista kestävää kehitystä käsittelevät maantieteen ylioppilaskokeen tehtävänannot edellyttävät. Kysymysten osatehtävät etenivät pääosin alemmilta ajattelun taidon tasoilta kohti vaativampia. Näin kysymykset auttavat jäsentämään vastaamista, johdattavat aiheeseen ja mahdollistavat sen, että heikoimmatkin opiskelijat saavat pisteitä. Koko kokeen tavoitteenahan on kokonaispisteissä lähes normaalijakauman mukainen pistejakauma. Toisena tavoitteenamme oli selvittää, millaisia ajattelun taidon tasoja vastauksissa esiintyy. Taloudellista kestävää kehitystä käsittelevät esseevastaukset sijoittuivat molemmissa tehtävänannoissa pääosin yksinkertaisiin ja monirakenteisiin SOLO-taksonomian tasoihin 2-3. Kevään 2019 tehtävänannossa hiekasta opiskelijoille oli annettu käyttöön runsaasti aineistoa haastavamman tehtävänannon sisällön vuoksi, mikä saattoi nostaa opiskelijoiden ajattelun taidon tasoja vastauksissa. Vain harva vastauksista kuitenkaan ylsi korkeimpiin ajattelutaidon tasoihin SOLO-taksonomiassa, vaan vastaukset ylsivät keskimäärin usein vain pinnalliseen tarkasteluun, eikä käsiteltyihin teemoihin juurikaan syvennytty. Kirjoitusasu oli monissa vastauksissa huolimatonta ja epäjohdonmukaista, mikä alensi vastausten SOLO-taksonomian mukaista luokkaa. Ansioituneimmat vastaukset etenivät loogisesti, olivat helppolukuisia ja esiin nostetut aiheet oli kytketty laajempaan kontekstiin ja niiden välisiä syy-seuraussuhteita tarkasteltiin maantieteellisellä otteella.

Tulostemme perusteella olemme samaa mieltä kuin Fahmy (2018), että SOLO-taksonomia onnistuu kertomaan maantieteen ylioppilaskokeiden esseevastausten kypsyydestä, jäsentelystä ja aiheen käsittelyn syvällisyydestä eli ajattelun taidon tasoista, mutta se ei kykene täysin tunnistamaan määrällisesti huomioitavia asiasisältöjä vastauksissa. Ylioppilastutkintolautakunnan julkaisemissa hyvän vastauksen piirteissä tuodaan usein esille myös vastauksen määrällistä ulottuvuutta. Siksi SOLOtaksonomian mukainen luokittelu ei kerro ylioppilaskokeessa menestymisestä, vaan se soveltuu juurikin siihen mihin se on kehitetty eli avoimissa tekstivastauksissa ilmenevien ajattelun taidon tasojen analysointiin.

Kolmantena tavoitteenamme oli tarkastella sitä, mitä sisältöjä opiskelijat osasivat taloudelliseen kestävään kehitykseen liittyen. Keskeinen havaintomme vastausten sisällöistä oli, että opiskelijat eivät vastauksissaan juurikaan osanneet tuoda esille tai selittää kestävän kehityksen perimmäistä ajatusta eli sitä, että taloudellinen kehitys ja sen vaikutukset eivät saisi tapahtua ympäristön ja tulevien sukupolvien kustannuksella. Opiskelijat toki osasivat pohtia kestävään kehitykseen liittyviä sisältöjä. Havaintomme on linjassa Tanin ja muiden (2020, s. 14) pohdinnan kanssa, että maantieteen ylioppilaskokeiden perusteella opetuksessa ja arvioinnissa tulisi kiinnittää enemmän huomiota maantieteellisten ja maantieteelle ominaisten käsitteiden osaamiseen. Tämän maantieteen perusosaamisen varaan voidaan sitten rakentaa odotuksia vaativammista ajattelun taidon tasoista ja vaativammista maantieteen ylioppilaskokeiden kysymyksistä ja tehtävänannoista. Tuloksemme osoittavat lisäksi, että lukion maantieteen opetuksen ja maantieteen aineenopettajien tulisi keskittyä 
Ainedidaktiikka 4(3) (2020)

entistä enemmän kestävän kehityksen teemojen tarkasteluun ja sen varmistamiseen, että opiskelijat todella ymmärtävät teemojen keskeiset käsitteet, syvemmän luonteen ja problematiikan. Tutkimuksessamme huomasimme, että opiskelijoilla oli jonkinlaista osaamista taloudellisesti kestävästä kehityksestä, mutta syvempi ymmärtäminen ja syy-seuraussuhteiden näkyminen vastauksissa oli heikkoa. Näkemyksemme mukaan opettajien tulisi opettaa kestävää kehitystä monipuolisten esimerkkien kautta, mutta kuitenkin painottaen, että taloudellinen kehitys ei saisi tapahtua ympäristön tai tulevien sukupolvien elinmahdollisuuksien kustannuksella. Lisäksi lukio-opetuksessa ja ylioppilaskokeisiin valmistautumisessa opettajien johdolla tulisi entistä enemmän harjoitella muun muassa vastaustekniikkaa, esseevastausten jäsentelyä ja syy-seuraussuhteiden perustelemista. Opettajien tulisi myös enemmän opastaa opiskelijoita näkemään alakohdista koostuva kysymys kokonaisuutena - ja harjoitella vastaamaan sen mukaisesti.

Tutkimuksemme tarkasteli taloudellisen kestävän kehityksen sisältöjen hallintaa ja osaamista vain maantieteen ylioppilaskokeen näkökulmasta. Tämä antaa kuitenkin vain kapean näkökulman laajaan aiheeseen, koska kestävä kehitys on monia oppiaineita yhdistävä teema. Siksi olisi jatkossa hyödyllistä tutkia miten eri oppiaineiden (esimerkiksi maantiede, terveystieto, biologia ja yhteiskuntaoppi) ylioppilaskokeiden vastauksissa näkyy kestävään kehitykseen liittyvät sisällöt. Voitaisiinko tällaisella tutkimuksella jatkossa selvittää, osaavatko opiskelijat soveltaa muissa oppiaineissa kestävästä kehityksestä oppimaansa jonkin toisen oppiaineen ylioppilaskokeessa? Toisaalta olisi myös hyvä selvittää ja vertailla kuinka kestävään kehitykseen liittyviin kysymyksiin vastataan eri oppiaineiden ylioppilaskokeissa. Tämän tärkeyttä korostaa se, että kestävä kehitys on ja tulee tulevaisuudessakin olemaan oppiainerajoja ylittävä ja oppiaineita yhdistävä ja opetettava tärkeä teema.

\section{Lähteet}

Aarnio-Linnanvuori, E. (2016). Ympäristöaiheiden tieteidenvälisyys yleissivistävän opetuksen haasteena aineenopettajien näkökulmasta. Kasvatus \& Aika, 10(2), 33-50. https://journal.fi/kasvatusjaaika/article/view/68622

Aarnio-Linnanvuori, E. \& Ahvenisto, I. (2013). Koulutuspolitiikka ja realismi ristiriidassa? Kestävä kehitys peruskoulun ja lukion taloustiedon oppikirjoissa. Teoksessa L. Tainio, K. Juuti \& S. Routarinne (toim.), Ainedidaktinen tutkimus koulutuspoliittisen päätöksenteon perustana (ss. 49-67). Helsinki: Suomen ainedidaktinen tutkimusseura. http://hdl.handle.net/10138/38459

Aksela, M., Kärnä, P. \& Tikkanen, G. (2012). Mielekäs luonnontieteiden opetus: Miten tukea oppilaiden ajattelua ja ymmärtämistä? Teoksessa P. Kärvä, L. Houtsonen \& T. Tähkä (toim.), Luonnontieteiden opetuksen kehittämishaasteita 2012 (ss. 9-28). Helsinki: Opetushallitus.

Anderson, L. W. \& Krathwohl, D. R. (toim.) (2001). A taxonomy for learning, teaching, and assessing: A revision of bloom's taxonomy of educational objectives. New York: Longman.

Atjonen, P. (2007). Hyvä, paha arviointi. Helsinki: Tammi.

Biggs, J. (1999). Teaching for quality learning at university. Suffolk: Society for Research into Higher Education \& Open University Press.

Biggs, J. \& Collis, K. (1982). Evaluating the quality of learning: The SOLO taxonomy. New York: Academic Press.

Biggs, J. \& Tang, C. (2011). Teaching for quality learning at university (4. painos). Maidenhead: McGraw-Hill/Society for Research into Higher Education/Open University Press. 


\section{Ainedidaktiikka 4(3) (2020)}

Bloom, B. S. (toim.) (1956). Taxonomy of educational objectives - handbook 1: Cognitive domain. London: Longmans.

Cantell, H. (2011). Maantieteen opetus globaalin ymmärryksen edistäjänä. Terra, 123(1), $3-15$.

Cantell, H. (2015). Ainejakoisuus ja monialainen eheyttäminen opetuksessa. Teoksessa H. Cantell (toim.), Näin rakennat monialaisia oppimiskokonaisuuksia (ss. 11-15). Jyväskylä: PS-kustannus.

Cantell, H., Rikkinen, H. \& Tani, S. (2007). Maailma minussa - minä maailmassa: Maantieteen opettajan käsikirja. Helsinki: Helsingin yliopisto, Soveltavan kasvatustieteen laitos.

Charles, C. (1996). Ecological literacy is not enough. International Research in Geographical and Environmental Education, 5(2), 133-135. https://doi.org/10.1080/10382046.1996.9965000

Elo, S. \& Kyngäs, H. (2007). The qualitative content analysis process. Journal of Advanced Nursing, 62(1), 107-115. https://doi.org/10.1111/j.1365-2648.2007.04569.x

Elo, S., Kääriäinen, M., Kanste, O., Pölkki, T, Utriainen, K. \& Kyngäs, H. (2014). Qualitative content analysis: a focus on trustworthiness. SAGE Open, 4(1). https://doi.org/10.1177/2158244014522633

Engeström, Y. (1984). Perustietoa opetuksesta. Helsinki: Valtiovarainministeriö. http://hdl.handle.net/10224/3665

Fahmy, T. M. (2018). Ylioppilaskokelaiden aluemaantieteelliset ajattelutaidot. (Väitöskirja). Turun yliopisto. http://urn.fi/URN:NBN:fi-fe2018100337248

Gillette, B. (2015). The nature and process of science and applications to geography education: A US perspective. International Research in Geographical and Environmental Education, 24(1), 6-12. https://doi.org/10.1080/10382046.2014.967112

Haapanen, M. (2018). Geomedia- ja vastaustaidot maantieteen sähköisissä ylioppilaskirjoituksissa. (Pro gradu -tutkielma). Helsingin yliopisto. http://urn.fi/URN:NBN:fi-fe201804208583

Hannula, J. (2019). Kehittämistutkimus: Matematiikan aineenopettajaopiskelijoiden matemaattisen ja pedagogisen sisältötiedon edistäminen ongelmalähtöisessä oppimisessa. (Väitöskirja) Helsingin yliopisto. http://urn.fi/URN:ISBN:978-951-51-5323-4

Havukainen, P. (2003). Terveysalan opiskelijoiden hoitotyön oppiminen esseevastausten perusteella arvioituna. (Väitöskirja) Helsingin yliopisto. http://urn.fi/URN:ISBN:952-10-0796-6

Koskinen, H. I. (2005). Yliopistotentin murros: SOLO-taksonomia eläinlääketieteellisen lisääntymistieteen oppimistulosten arvioinnissa. (Väitöskirja) Helsingin yliopisto. http://urn.fi/URN:ISBN:952-10-2665-0

Krathwohl, D. R. (2002). A revision of Bloom's taxonomy: An overview. Theory into Practice, 41(4), 212-218. https://doi.org/10.1207/s15430421tip4104_2

Lahti, L. K. (2005). Ympäristö- ja luonnontieto -nimisen oppiainekokonaisuuden asema Suomessa. Teoksessa J. Enkenberg, J. Savolainen \& P. Väisänen (toim.), Tutkiva opettajankoulutus - taitava opettaja (ss. 128-136). Savonlinna: Savonlinnan opettajankoulutuslaitos, Joensuun yliopisto.

http://sokl.uef.fi/verkkojulkaisut/tutkivaope/pdft/lahti.pdf

Lambert, D. (2017). Powerful disciplinary knowledge and curriculum futures. Teoksessa N. Pyyry, L. Tainio, K. Juuti, R. Vasquez \& M. Paananen (toim.), Changing subjects, changing pedagogies: Diversities in school and education (ss. 14-31). Helsinki: Suomen ainedidaktinen tutkimusseura. http://hdl.handle.net/10138/231202

Lambert, D., Solem, M. \& Tani, S. (2015). Achieving human potential through geography education: A capabilities approach to curriculum making in schools. Annals of the Association of American Geographers, 105(4), 723-735. https://doi.org/10.1080/00045608.2015.1022128

Leivo, J. (2020). Ajattelun taidon tasot maantieteen sähköisissä ylioppilaskokeissa kestävän kehityksen koekysymyksissä ja vastauksissa. (Pro gradu -tutkielma). Helsingin yliopisto. http://urn.fi/URN:NBN:fi:hulib-202005202240

Linkola, H. (2014). Maantiede menetti yhden pakollisen lukiokurssin. Terra, 126(4), 197-199.

Linkola, H. (2016). Maantieteen ylioppilaskoe sähköistyy. Terra, 128(2), 117-119. 


\section{Ainedidaktiikka 4(3) (2020)}

Morgan, A. (2011). Morality and geography education. Teoksessa G. Butt (toim.), Geography, education and the future (ss. 187-205). London: Continuum.

Muukkonen, P. (2017). Maantieteen oppituntien sisällöt ja niiden käsittely kulttuurisesti moninaisessa luokassa: Opettajien kokemuksia mahdollisuuksista ja haasteista. Terra, 129(1), 17-27. http://hdl.handle.net/10138/298520

Muukkonen, P. (2018). Maantieteen opettajien opetuskäytännöt kielellisesti moninaisessa luokassa. Teoksessa R. Rinne, N. Haltia, S. Lempinen \& T. Kaunisto (toim.), Eriarvoistuva maailma - tasa-arvoistava koulu? (sss 297-328). Jyväskylä: Suomen kasvatustieteellinen seura. http://hdl.handle.net/10138/287681

Muukkonen, P. (2019). Olika arbetssätt hos geografilärare i mångkulturella klassrum. Terra, 131(3), 165-167. https://terra.journal.fi/article/view/78036/

Opetushallitus (2014). Perusopetuksen opetussuunnitelman perusteet 2014. Helsinki: Opetushallitus.

Opetushallitus (2015). Lukion opetussuunnitelman perusteet 2015. Helsinki: Opetushallitus.

Opetushallitus (2019). Lukion opetussuunnitelman perusteet 2019. Helsinki: Opetushallitus.

Repo, R. (2005). Arviointi oppimisprosessin osana - autenttinen arviointi. Teoksessa A. Kallioniemi \& J. Luodeslampi (toim.), Uskonnonopetus uudella vuosituhannella (ss. 232-246). Helsinki: Kirjapaja.

Rickinson, M., Lundholm, C. \& Hopwood, N. (2009). Environmental learning: Insights from research into the student experience. Dordrecht: Springer. https://doi.org/10.1007/978-90-481-2956-0

Tani, S. (2014). Geography in the Finnish school curriculum: Part of the 'success story'? International Research in Geographical and Environmental Education, 23(1), 90 101. https://doi.org/10.1080/10382046.2013.858457

Tani, S. (2017). Maantieteen opetuksen haasteita: Digitalisaatio, opetuksen eheyttäminen ja opettajan roolin muutos. Terra, 129(4), 211-222.

Tani, S., Cantell, H. \& Hilander, M. (2020). Ylioppilaskokeet ja maantieteen merkityksellinen tieto. Terra, 132(1), 3-16. https://doi.org/10.30677/terra.82739

Tikkanen, G. (2010). Kemian ylioppilaskokeen tehtävät summatiivisen arvioinnin välineenä. (Väitöskirja). Helsingin yliopisto. http://urn.fi/URN:ISBN:978-952-10-6336-7

Torbjörnsson, T. \& Molin, L. (2014). Who is solidary? A study of Swedish students' attitudes towards solidarity as an aspect of sustainable development. International Research in Geographical and Environmental Education, 23(3), 259-277. https://doi.org/10.1080/10382046.2014.886153

Tuncer, G. \& Sahin, E. (2016). Message in a bottle: What shapes university students' understanding of sustainability? International Research in Geographical and Environmental Education, 25(4), 264-308. https://doi.org/10.1080/10382046.2016.1207994

World Commission on Environment and Development (1987). Report of the World Commission on Environment and Development: Our Common Future. New York: United Nations. https://sustainabledevelopment.un.org/content/documents/5987our-common-future.pdf

Ylioppilastutkintolautakunta (2018). Tiedote maantieteen opettajille ja opiskelijoille: Maantieteen digitaalinen ylioppilaskoe. Helsinki: Ylioppilastutkintolautakunta. https://www.ylioppilastutkinto.fi/images/sivuston tiedostot/Sahkoinen tutkinto/ge tiedote fi.pdf

Ylioppilastutkintolautakunta (2020a). Hyvän vastauksen piirteet. Helsinki: Ylioppilastutkintolautakunta.

https://www.ylioppilastutkinto.fi/ylioppilastutkinto/hyvan-vastauksen-piirteet

Ylioppilastutkintolautakunta (2020b). Tilastotaulukot. Helsinki: Ylioppilastutkintolautakunta. https://www.ylioppilastutkinto.fi/tietopalvelut/tilastot/tilastotaulukot

Ylioppilastutkintolautakunta (2020c). Vanhat kokeet. Helsinki: Ylioppilastutkintolautakunta. https://www.ylioppilastutkinto.fi/tietopalvelut/vanhat-kokeet

Zoller, U. \& Pushkin, D. (2007). Matching higher-order cognitive skills (HOCS) promotion goals with problem-based laboratory practice in a freshman organic chemistry course. Chemistry Education Research and Practice, 8(2), 153-171. https://doi.org/10.1039/B6RP90028C 
LIITE 1. Rekonstruoidut tyypilliset vastaukset taloudellista kestävää kehitystä käsittelevään maantieteen ylioppilaskoekysymyksiin syksyllä 2018, kysymys 7: Kahvi ja globalisaatio (Ylioppilastutkintolautakunta, 2020b). Alakohtaa 7.2 ei ole huomioitu, koska siinä pyydettiin vain laatimaan diagrammi.

\begin{tabular}{|c|c|c|c|}
\hline \multirow{2}{*}{$\begin{array}{l}\text { SOLO-taksonomian } \\
\text { taso }\end{array}$} & \multicolumn{3}{|l|}{ Syksy 2018, kysymys 7: Kahvi ja globalisaatio } \\
\hline & $\begin{array}{l}\text { 7.1 Määrittele käsitteet globalisaatio ja rahakasvi. } \\
(6 \text { p.) }\end{array}$ & $\begin{array}{l}7.3 \text { Tarkastele karttoja (aineistot } 7 . B \text { ja } 7 . C \text { ) ja laatimaasi diagrammia. } \\
\text { Kuvaile niiden perusteella kahvin tuotannon ja kulutuksen alueellisia } \\
\text { piirteitä maapallolla. Pohdi syitä kahvin tuotannon ja kulutuksen } \\
\text { alueellisiin eroihin. ( } 10 \text { p.) }\end{array}$ & $\begin{array}{l}\text { 7.4 Pohdi, miten reilu kauppa vaikuttaa } \\
\text { kahvin viljelijöihin, kauppiaisiin ja } \\
\text { kuluttajiin. (8 p.) }\end{array}$ \\
\hline $\begin{array}{l}\text { 1. Esirakenteinen } \\
\text { vastaus }\end{array}$ & $\begin{array}{l}\text { ”Globalisaatio on maailmanlaajuista eli maat } \\
\text { tekevät enemmän yhteistyötä keskenään. } \\
\text { Rahakasvilla tarkoitetaan kasvia, jota viljellään } \\
\text { paljon ja sen tuottaminen on halpaa mutta kysyntä } \\
\text { korkeaa. Sillä valtio saa suurimman osan } \\
\text { tuloistaan.”[rekonstruoitu tyypillinen vastaus, } \\
\text { SOLO taso 1] }\end{array}$ & $\begin{array}{l}\text { "Kahvi kasvaa eteläisellä pallonpuoliskolla, koska siellä on sille parhaat } \\
\text { olosuhteet. Kahvia kulutetaan niissä maissa, missä sitä ei kasva. } \\
\text { Pohjoisessa juodaan kahvia ehkä siksi, että siellä on niin kylmä ja kahvi } \\
\text { lämmittää. Kahvin juonti kuuluu myös suomalaiseen kulttuuriin, kun kahvia } \\
\text { menee monta kuppia päivässä. Kahvista on myös apua hereillä } \\
\text { pysymiseen." [rekonstruoitu tyypillinen vastaus, SOLO taso 1] }\end{array}$ & $\begin{array}{l}\text { "Reilu kauppa vaikuttaa viljelijöihin, } \\
\text { kauppiaisiin ja kuluttajiin niin, että } \\
\text { viljelijät saavat paremmat olot, kauppiaille } \\
\text { se maksaa ja kuluttajat tietävät, mistä } \\
\text { kahvi tulee." [rekonstruoitu tyypillinen } \\
\text { vastaus, SOLO taso 1] }\end{array}$ \\
\hline $\begin{array}{l}1 \mathrm{~A} . \\
\text { Esirakenteisen } \\
\text { siirtymävaihe }\end{array}$ & $\begin{array}{l}\text { "Globalisaatio tarkoittaa eri maiden toimintaa } \\
\text { yhdessä ja sitä, että kulttuurit sekoittuvat ja } \\
\text { kaupungistuminen lisä̈̈ntyy. } \\
\text { Maailmanlaajuistuminen on helpottunut internetin } \\
\text { avulla. Rahakasvi on kasvi, jolla ei ole muuta kuin } \\
\text { rahallista hyötyä kasvattajalle. Kun se kasvatetaan } \\
\text { niin se myydään kalliimalla rikkaampiin maihin. } \\
\text { Niistä saatava rahaosuus on suuri. Rahakasveja } \\
\text { ovat esimerkiksi kahvi ja tupakka." [rekonstruoitu } \\
\text { tyypillinen vastaus, SOLO taso 1A] }\end{array}$ & $\begin{array}{l}\text { "Kahvia tuotetaan päiväntasaajan alapuolella eli eteläisellä } \\
\text { pallonpuoliskolla. Siellä on viljelyyn suotuisat olosuhteet eli lämpötila. } \\
\text { Kahvin tuottaminen on yleensä helppoa ja siitä saa hyvin rahaa. Kahvi on } \\
\text { rahakasvi ja sen avulla köyhemmät ihmiset voivat kerätä rahaa. } \\
\text { Pohjoisessa juodaan kahvia enemmän kuin etelässä. Pohjoisessa suurimpia } \\
\text { kahvin kuluttajamaita ovat pohjoismaat. Siellä ei ole paljoa auringonvaloa, } \\
\text { minkä vuoksi kahvia juodaan paljon piristeenä. Yleisesti taloudellisesti } \\
\text { rikkaammat valtiot kuluttavat kahvia paljon ja kulutuserot johtuvat } \\
\text { taloudellisesta tilanteesta. Köyhien maiden ihmisillä ei ole juuri varaa } \\
\text { ostaa kahvia vaan he käyttävät rahat ruokaan." [rekonstruoitu tyypillinen } \\
\text { vastaus, SOLO taso 1A] }\end{array}$ & $\begin{array}{l}\text { "Reilun kaupan tuottajille voidaan maksaa } \\
\text { parempaa palkkaa ja kunnollinen hinta } \\
\text { pavuista. Kuluttaja tekee päätöksen siitä, } \\
\text { ostaako kalliimpia reilun kaupan kahveja } \\
\text { vai halvempia tavallisia tuotteita. } \\
\text { Suosittelen kuluttajille reilun kaupan } \\
\text { kahvia, koska siitä on hyötyä kasvattajalle. } \\
\text { Kauppiaalle kahvi on kallista." } \\
\text { [rekonstruoitu tyypillinen vastaus, SOLO } \\
\text { taso 1A] }\end{array}$ \\
\hline $\begin{array}{l}\text { 2. Yksinkertainen } \\
\text { vastaus }\end{array}$ & $\begin{array}{l}\text { ”Globalisaatio tarkoittaa maailmanlaajuista } \\
\text { toimintaa ja verkostoitumista. Siinä olemme } \\
\text { tekemisissä toistemme kanssa enemmän ja } \\
\text { enemmän. Asiat liikkuvat nopeammin ja } \\
\text { esimerkiksi globaalisuutta voi tarkastella talouden } \\
\text { tai politiikan pohjalta." [rekonstruoitu tyypillinen } \\
\text { vastaus, SOLO taso 2] }\end{array}$ & $\begin{array}{l}\text { ”Kahvia tuotetaan sellaisissa maissa, missä se on ilmaston puolesta } \\
\text { mahdollista. Eteläisellä pallonpuoliskolla on lämmintä ja kosteaa ja siellä } \\
\text { kahvi kasvaa hyvin. Kahvia taas kulutetaan enemmän pohjoisella } \\
\text { pallonpuoliskolla. Kahvi on ylellisyystuote ja siksi kaikilla ei siihen ole } \\
\text { varaa. Suurimpia kuluttajia ovat pohjoismaat, länsi- ja keski-Eurooppa, } \\
\text { Yhdysvallat ja Kanada. Kahvia tuotetaan Afrikan keskiosissa ja Etelä- } \\
\text { Amerikan yläosissa. Pohjoismaissa juodaan aineiston mukaan eniten } \\
\text { kahvia koko maailmassa. Kahvi on kuumaa ja siksi sitä juodaan mieluiten } \\
\text { kylmillä kuin kuumilla alueilla. Kahvi on myös kallis tuote, eikä kaikilla ole } \\
\text { siihen varaa. Köyhien maiden tuottajien pitää saada sato myytyä } \\
\text { kalliimmalla muille, jotta itse pärjäävät taloudellisesti. Kahviplantaaseilla } \\
\text { on myös paljon työvoimaa, jotka ovat huonosti palkattuja." [rekonstruoitu } \\
\text { tyypillinen vastaus, SOLO taso 2] }\end{array}$ & $\begin{array}{l}\text { "Reilun kaupan mukaan viljelijän pitää } \\
\text { saada työstään kohtuullinen korvaus eikä } \\
\text { alueella saa käyttää lapsityövoimaa. } \\
\text { Kauppiaat eivät voi alistaa työläisiä. Reilu } \\
\text { kauppa on myös } \\
\text { ympäristöystävällisempää. Kauppias } \\
\text { joutuu maksamaan tuotteesta enemmän, } \\
\text { jotta saa sen myyntiin ja siksi ne maksavat } \\
\text { myös asiakkaille enemmän. Kuluttaja } \\
\text { päättää itse ostamisesta, mutta kyllä se } \\
\text { tuntuu hyvälttä ostaa sellaisia tuotteita, } \\
\text { joiden tietää olevan hyvin tuotettuja eikä } \\
\text { ihmisoikeuksia ole rikottu. Ne maksavat }\end{array}$ \\
\hline
\end{tabular}




\begin{tabular}{|c|c|c|c|}
\hline & & & $\begin{array}{l}\text { kuitenkin enemmän, mutta se hinta } \\
\text { kannattaa maksaa.” [rekonstruoitu } \\
\text { tyypillinen vastaus, SOLO taso 2] }\end{array}$ \\
\hline $\begin{array}{l}2 \mathrm{~A} . \\
\text { Yksinkertaisen } \\
\text { siirtymävaihe }\end{array}$ & $\begin{array}{l}\text { "Globalisaatio tarkoittaa kansainvälistymistä. } \\
\text { Siinä keskitytä̈̈n oman kansan sijaan } \\
\text { kansainväliseen yhteistyöhön muiden maiden } \\
\text { kanssa. Globalisaatiolla on positiivisia ja } \\
\text { negatiivisia puolia. Hyvät vaikutteet, kuten } \\
\text { ketjuravintolat, leviävät laajalle alueelle, mutta } \\
\text { toisaalta maailmasta voi tulla globalisaation } \\
\text { vuoksi liian samanlainen. Myös esimerkiksi } \\
\text { tehtaiden siirtäminen ulkomaille on osa } \\
\text { globalisaatiota. Rahakasvi on kasvi, jota } \\
\text { tuottamalla viljelijämaa saa enemmän rahaa kuin } \\
\text { jonkun muun kasvin tuottamisesta. Rahakasvien } \\
\text { viljely vie tilaa ruokakasvien viljelyltä, mikä } \\
\text { vaikuttaa negatiivisesti asukkaiden elämä̈̈̈n. } \\
\text { Rahakasveja ei myös yleensä voi käyttää ruoaksi, } \\
\text { koska ne ovat nautintoaineita, kuten tupakkaa ja } \\
\text { kahvia." [rekonstruoitu tyypillinen vastaus, SOLO } \\
\text { taso 2A] }\end{array}$ & $\begin{array}{l}\text { ”Aineistosta huomaa, että kahvia tuotetaan eniten Etelä-Amerikassa, } \\
\text { Aasiassa ja Afrikassa. Kahvin kulutus taas sijoittuu enemmän Länsi-, } \\
\text { Keski-ja Pohjois-Euroopassa, Pohjois-Amerikassa ja Japanissa sekä } \\
\text { Brasiliassa. Kahvia kulutetaan paljon myös Australiassa ja Uudessa- } \\
\text { Seelannissa. Kahvin tuotantoa on eniten siellä, missä elintaso on alhainen. } \\
\text { Ilmasto vaikuttaa paljon kahvin kasvatukseen ja siksi kahvintuotanto on } \\
\text { sijoittunut päiväntasaajan alueille. Kahvi tarvitsee paljon auringonvaloa ja } \\
\text { hedelmällisen maaperän. Kulutus tapahtuu pääosin rikkaissa } \\
\text { teollisuusmaissa, missä ihmisillä on varaa käyttää rahaa sellaisiin } \\
\text { tuotteisiin, jotka eivät ole heille elintärkeitä selviämiselle. Köyhempien } \\
\text { maiden asukkaat eivät voi käyttää rahaa tällaisiin tuotteisiin, koska heidän } \\
\text { on turvattava perheensä selviäminen ja ruoansaanti. Esimerkiksi Suomessa } \\
\text { kahvi on osa jokapäiväistä kulttuuria, jonka vuoksi sitä käytetään niin } \\
\text { paljon. Eteläisissä maissa tällaista kulttuuria ei ole syntynyt yhtä vahvasti, } \\
\text { jonka vuoksi kahvin kulutus on alhaisempaa." [rekonstruoitu tyypillinen } \\
\text { vastaus, SOLO taso 2A] }\end{array}$ & $\begin{array}{l}\text { ”Reilu kauppa tarkoittaa sitä, että } \\
\text { suurempi osa voitoista menee viljelijälle } \\
\text { tai viljelymaan hyväksi, eikä suuren } \\
\text { yrityksen taskuun, niin kuin normaalissa } \\
\text { kaupassa yleensä käy. Kauppias joutuu } \\
\text { maksamaan korkeamman hinnan } \\
\text { saadakseen tuotteet myyntiin, mutta } \\
\text { tuotteiden hyvä mainos on sitäkin } \\
\text { arvokkaampaa. Kuluttajalla on } \\
\text { mahdollisuus valita sellainen tuote, joka } \\
\text { tukee paikallisten viljelijöiden pärjäämistä } \\
\text { ja yhä enemmän ihmiset näin tekevätkin. } \\
\text { Yksittäiselle ihmiselle hinta ei ole niin } \\
\text { kova mitä sen aiheuttama positiivinen } \\
\text { vaikutus paikallisille on." [rekonstruoitu } \\
\text { tyypillinen vastaus, SOLO taso 2A] }\end{array}$ \\
\hline $\begin{array}{l}\text { 3. Monirakenteinen } \\
\text { vastaus }\end{array}$ & $\begin{array}{l}\text { "Globalisaatiolla tarkoitetaan maiden väestöjen, } \\
\text { yhteyksien, kulttuurien, palveluiden ja resurssien } \\
\text { leviämistä ympäri maailmaa. Globalisaatio johtaa } \\
\text { "välimatkojen" lyhentymiseen ja lähentää ihmisiä } \\
\text { ja vuorovaikutusta. Myös erilaiset maapalloa } \\
\text { koskevat globaalit kriisit kuten ilmastonmuutos } \\
\text { leviävät laajemmin globalisaation seurauksena. } \\
\text { Rahakasvi on suurilla plantaaseilla tuotettu kasvi, } \\
\text { joka on suunnattu vientiin. Paikalliset eivät hyödy } \\
\text { rahakasvista juurikaan, toisin kuin yritykset, jotka } \\
\text { paikallisten mailla kasvia viljelevät. Rahakasvien } \\
\text { viljely johtaa paikallisten huonoihin oloihin ja } \\
\text { köyhyyteen, koska heille ei jää työstä juurikaan } \\
\text { tuottoja." [rekonstruoitu tyypillinen vastaus, } \\
\text { SOLO taso 3] }\end{array}$ & $\begin{array}{l}\text { "Kahvin tuotanto keskittyy kehitysmaihin ja päiväntasaajan eteläpuolisiin } \\
\text { valtioihin. Etelä-Amerikka, Afrikan keskiosat, kaakkois-Aasia ja Oseania } \\
\text { ovat tällaisia alueita. Näillä alueilla ilmaston on sopiva kahvinviljelyyn. } \\
\text { Alueilla väestönmäärä on myös korkeaa ja työvoimaa on paljon saatavilla. } \\
\text { Pohjoisilla alueilla ilmasto-olot ovat kylmiä ja kuivia, eikä siksi olisi } \\
\text { järkevää viljellä kalliilla kahvia jossain, missä se ei ole kannattavaa, kun } \\
\text { muilla alueilla se on paljon helpompaa. Tropiikin alueet ovat lämpötilan ja } \\
\text { sademäärän vuoksi otollisia viljelyalueita. Suurimpia kahvintuottajamaita } \\
\text { ovat Burundi, Etiopia ja Ruanda. Kahvin kulutus keskittyy maapallon } \\
\text { pohjoisosiin eli Kanadaan, Eurooppaan ja erityisesti Pohjoismaihin. } \\
\text { Länsimaissa ja Suomessakin kahvi kuuluu jokapäiväiseen kulttuuriin, ja } \\
\text { lähestulkoon jokainen juo kahvia esimerkiksi töissä tai juhlissa. Tämä voi } \\
\text { johtua siitä, että pohjoiset alueet sijaitsevat maantieteellisesti } \\
\text { pohjoiskalotilla, jossa valoisan ajan pituus on ympärivuotisesti hyvin } \\
\text { vähäinen. Valoisuus vaikuttaa ihmisten mielialaan ja kahvilla yritetään } \\
\text { piristyä. Kahvi on myös addiktoivaa, mikä voi vaikuttaa käytön suureen } \\
\text { määrään.”. [rekonstruoitu tyypillinen vastaus, SOLO taso 3] }\end{array}$ & $\begin{array}{l}\text { ”Reilun kaupan tuotteet ovat tuotteita, } \\
\text { jotka tuotetaan ihmisoikeuksia } \\
\text { kunnioittaen ja paikallisten tulonsaannin } \\
\text { turvaten. Tuotteiden viljelijät saavat } \\
\text { kunnollista palkkaa ja heidän } \\
\text { työturvallisuuttaan tuetaan. Kukaan ei } \\
\text { tällöin vie rahaa välistä. Kauppiaat } \\
\text { saattavat menettää rahaa hankkiessaan } \\
\text { myyntiin kalliimmalla tuotettuja tuotteita, } \\
\text { mutta koska nykyään monet ihmiset } \\
\text { haluavat tukea oikeudenmukaista työtä, } \\
\text { myynti kasvaa ja tuotot nousevat } \\
\text { kauppiaalle. Kuluttajien kannalta tuotteet } \\
\text { on helppo huomata myynnissä ja ihmisten } \\
\text { on helppo vaikuttaa oikeudenmukaiseen } \\
\text { viljelyyn ostamalla näitä tuotteita. } \\
\text { Ostaessaan he myös tietävät, miten } \\
\text { tuotteet on tuotettu ja siksi myynti lisääa } \\
\text { tietoa aiheesta." [rekonstruoitu tyypillinen } \\
\text { vastaus, SOLO taso 3] }\end{array}$ \\
\hline $3 \mathrm{~A}$. & "Globalisaatio tarkoittaa maailmanlaajuistumisen & "Aineiston $7 B$ pohjalta voidaan havaita, että kahvin tuotanto sijoittuu & "Reilun kaupan tarkoituksena on turvata \\
\hline
\end{tabular}




\begin{tabular}{|c|c|c|c|}
\hline $\begin{array}{l}\text { Monirakenteisen } \\
\text { siirtymävaihe }\end{array}$ & $\begin{array}{l}\text { lisääntymistä ja yhteistyötä valtionraojen yli. } \\
\text { Globalisaatioon liittyy maailmankauppa ja tiedon } \\
\text { sekä kulttuurien leviäminen ympäri maailmaa. } \\
\text { Valtion rajojen merkitys vähenee ja muun } \\
\text { maailman yhtenäisyys lisääntyy. Jos omasta } \\
\text { maasta ei löydy haluaamaansa asiaa, voi sen } \\
\text { hankkia helposti muualta maailmasta. Teknologian } \\
\text { kehittymisen takia myös ihmisten välinen } \\
\text { kommunikaatio on helpompaa ja matkustaminen } \\
\text { on paljon nopeampaa kuin ennen. Rahakasveja } \\
\text { viljellään ainoastaan rahan vuoksi vientiin. } \\
\text { Esimerkiksi tupakka on rahakasvi, jota käytetään } \\
\text { nautintoaineena, niin kuin rahakasveja yleensä } \\
\text { käytetään. Rahakasveja tuotetaan plantaaseilla } \\
\text { esimerkiksi Etelä-Amerikassa eikä esimerkiksi } \\
\text { Kanadassa. Plantaasit raivataan sademetsien } \\
\text { tilalle ja niillä viljellään yksipuolisesti yhtä tai } \\
\text { kahta tuotetta, mikä pilaa maaperää eikä anna } \\
\text { valtiolle muuta kuin työpaikan viljelijöille." } \\
\text { [rekonstruoitu tyypillinen vastaus, SOLO taso 3A] }\end{array}$ & $\begin{array}{l}\text { Afrikan keskiosiin, Etelä-Amerikkaan ja Kaakkois-Aasian valtioihin ja } \\
\text { saarille. Valtiot sijaitsevat päiväntasaajan läheisyydessä, jossa ilmaston on } \\
\text { kosteaa runsaiden sateiden vuoksi, ilmasto lämmintä ja näin ollen otollista } \\
\text { kahvin viljelylle. Myös alueiden heikko taloudellinen tilanne on sellainen, } \\
\text { että siellä on helppo viljellä rahakasveja, jotka siirretään vientiin. Se on } \\
\text { halpaa halvan työvoiman vuoksi, eikä alueella tarvitse pohtia esimerkiksi } \\
\text { ihmisoikeuksia tai hyviä työoloja, jolla maksimoidaan tuotot. Diagrammeja } \\
\text { ja karttoja katsomalla nähdään, että mitä pohjoisemmas mennään, sitä } \\
\text { vähemmän kahvia siellä viljellään. Tämä johtuu päinvastaisesta ilmastosta, } \\
\text { mikä ei ole ollenkaan otollinen kahvin viljelyyn. Tulisi myös erittä̈in } \\
\text { kalliiksi tuottaa kylmille alueille keinotekoisesti ilmastollisesti hyviä } \\
\text { olosuhteita kahvin viljelyä varten. Kahvin kulutus on hajautunut enemmän } \\
\text { verrattuna tuotantoon, kun katsoo karttoja. Suurimmat kuluttaja-alueet } \\
\text { ovat Eurooppa, Pohjois-Amerikka, Brasilia, Australia ja Uusi-Seelanti, } \\
\text { Japani ja Algeria. Nämä ovat pääosin rikkaita teollisuusalueita. Kahvi on } \\
\text { ollut aikoinaan rikkaan yläluokan nautintoaine, minkä merkitys on jäänyt } \\
\text { elämään tähän päivään asti. Nykyään kahviin on varaa yhä useammilla, } \\
\text { mutta sen kalliin hinnan vuoksi sitä ei silti vielä käytetä ympäri maailmaa } \\
\text { kaikilla alueilla. Kahvin kulutus on kovaa esimerkiksi Suomessa, jossa } \\
\text { valoisan ajan määrä on pientä lähes ympäri vuoden maapallon } \\
\text { kallistuskulman vuoksi. Kahvissa on kofeiinia, joka piristää pimeinä } \\
\text { aikoina. Kahvista saa energiaa, jonka avulla jaksaa paremmin." } \\
\text { [rekonstruoitu tyypillinen vastaus, SOLO taso 3A] }\end{array}$ & $\begin{array}{l}\text { viljelijöiden työ ja tuotto heidän } \\
\text { tekemästään työstä. Sen avulla turvataan } \\
\text { työolot sekä varmistetaan, että viljelijä saa } \\
\text { työstään ansaitsemansa korvauksen, eikä } \\
\text { kaikki mene lyhentämättömänä } \\
\text { suuryritysten omaisuudeksi. Reilun kaupan } \\
\text { avulla voidaan vähentää halpatyövoiman } \\
\text { käyttöä ja parantaa työoloja sekä } \\
\text { vähentää lapsityövoimaa plantaaseilla. } \\
\text { Kauppiaille reilu kauppa tuo } \\
\text { mahdollisuuden tukea paikallisia } \\
\text { viljelijöitä ottamalla heidän tuotteitaan } \\
\text { myyntiin. Näin he antavat viljelijöiden } \\
\text { tukemisen mahdollisuuden myös } \\
\text { kuluttajille. Reilun kaupan tuotteet ovat } \\
\text { kalliimpia kauppiaalle ja kuluttajalle kuin } \\
\text { halpatyövoiman avulla tuotetut, mutta } \\
\text { jokainen voi tehdä itse eetisen valinnan ja } \\
\text { päätöksen siitä, mitä he haluavat tukea.” } \\
\text { [rekonstruoitu tyypillinen vastaus, SOLO } \\
\text { taso 3A] }\end{array}$ \\
\hline $\begin{array}{l}\text { 4. Relationaalinen } \\
\text { vastaus }\end{array}$ & $\begin{array}{l}\text { "Globalisaatio on maailmanlaajuista } \\
\text { vuorovaikutusta eri alueiden välillä. Globalisaatio } \\
\text { kattaa viisi osa-aluetta: kulttuurisen, liikenteen ja } \\
\text { informaation, talouden, politiikan ja ympäristön } \\
\text { globalisaation. Se on kansainvälistä verkottumista, } \\
\text { informaation ja tiedon leviämistä. Globalisaatio } \\
\text { on positiivista, kun eri innovaatiot ja aatteet } \\
\text { leviävät ja tuottavat hyviä seurauksia, mutta } \\
\text { negatiivisten ilmiöiden, kuten ilmastonmuutoksen, } \\
\text { leviäminen ja vaikutus kaikille maailman alueille } \\
\text { on myös seurausta globalisaatiosta, joka vaatii } \\
\text { kaikkien valtioiden toimintaa ongelman } \\
\text { ehkäisemiseksi. } \\
\text { Rahakasvi on kasvi, joiden viljely vaatii tietyt } \\
\text { olosuhteet, minkä vuoksi niiden viljely tapahtuu } \\
\text { usein pienellä alueella. Rahakasveja ovat } \\
\text { hintavammat kulutustuotteet, kuten kahvi ja } \\
\text { tupakka, joiden saatavuus ei ole yhtä hyvää } \\
\text { kaikille maailman alueilla. Sitä viljellään varta } \\
\text { vasten myyntiin, eikä se edesauta viljelijämaan } \\
\text { taloudellista tilaa juurikaan, koska viljelmien }\end{array}$ & $\begin{array}{l}\text { ”Aineistosta } 7 \text { n nähdään, että kahvia viljellään pääosin kehittyvillä } \\
\text { alueilla kuten Afrikassa, Indoneisassa ja Etelä-Amerikassa. Diagrammista } \\
\text { nähdään, että eniten kahvia tuottavat maat sijaitsevat myös näillä alueilla. } \\
\text { Burundissa kahvin osuus kokonaisvientituloista vuosina 2000-2010 on } \\
\text { melkein } 60 \% \text { koko valtion kokonaisvientituloista. Vaikutukset olisivat siis } \\
\text { todella suuret, jos kahvin tuotannolle tapahtuisi jotain. Vaikka nämä alueet } \\
\text { tuottavat todella paljon kahvia, ne eivät kuitenkaan aineiston kartan } \\
\text { mukaan kuluta sitä yhtä paljon kuin maailman muut alueet. Eteläisellä } \\
\text { pallonpuoliskolla kahvin tuotanto on suurta kun taas pohjoisella } \\
\text { pallonpuoliskolla kuten Pohjoismaissa, Hollannissa ja Sveitsissä kulutus on } \\
\text { korkeaa, jopa 6,8-12,0 kiloa henkilöä kohden vuodessa. Aineistosta } \\
\text { nähdään nykypäivän trendi: kahvin tuotanto tapahtuu kehittyvissä maissa, } \\
\text { mutta sitä käyttävät enemmän teollisuusmaat. Poikkeuksena tässä on } \\
\text { Brasilia, joka sekä tuottaa että kuluttaa kahvia varsin paljon. Tähän syynä } \\
\text { voi olla eriarvoisten ihmisten määrä valtiossa: ne, joilla on varaa ostaa } \\
\text { kahvia, voivat sen tehdä. Kahvin tuotanto vaatii otollisen ilmaston ja hyvän } \\
\text { maaperän, joka tuottaja-alueilta löytyy. Trooppinen ilmasto on hyvä kahvin } \\
\text { kasvulle. Näiden alueiden teollisuus perustuu raaka-aineiden tuottamiseen } \\
\text { eli ne viljelevät raaka-aineita vientiin, mutta eivät itse jalosta niitä } \\
\text { eteenpäin. Kehitysmailla ei ole edellytyksiä viedä jalostusta eteenpäin vaan } \\
\text { niiden myynti on riippuvaista teollisuusmaista. Rahakasvit ovat }\end{array}$ & $\begin{array}{l}\text { ”Reilun kaupan tuotteet on eettisesti } \\
\text { tuotettuja ja ne takaavat viljelijöille } \\
\text { paremmat olot sekä vakaammat tulot. } \\
\text { Reilu kauppa ehkäisee alueen korruptiota, } \\
\text { mikä johtaa siihen, että sillä on suuri } \\
\text { merkitys viljelijöiden elämä̈̈n ja } \\
\text { valtioiden olojen parantamiseen. } \\
\text { Kauppiaille reilun kaupan tuotteet lisäävät } \\
\text { niiden hintaa, mutta nykypäivän } \\
\text { tietoyhteiskunnassa halpatyövoimalla } \\
\text { tuotettujen tuotteiden myyminen ei ole } \\
\text { hyvää mainosta yritykselle. Kuluttaja } \\
\text { asiakkaat ovat jo hyvin tietoisia siitä, } \\
\text { millaisissa oloissa kehittyvien maiden } \\
\text { työläiset joutuvat tekemä̈̈n töitä ja } \\
\text { haluavat tukea heidän parempia } \\
\text { elinolojaan kaikilla keinoilla. Yksi } \\
\text { vaikuttamisen keino on Reilun kaupan } \\
\text { tuotteiden ostaminen ja niistä hieman } \\
\text { enemmän maksaminen." [rekonstruoitu } \\
\text { tyypillinen vastaus, SOLO taso 4] }\end{array}$ \\
\hline
\end{tabular}




\begin{tabular}{|c|c|c|c|}
\hline & $\begin{array}{l}\text { pääasiallinen tuotto siirtyy kansainvälisille } \\
\text { yrityksille." [rekonstruoitu tyypillinen vastaus, } \\
\text { SOLO taso 4] }\end{array}$ & $\begin{array}{l}\text { tuottoisimpia vientituotteita ja siksi maat viljelevät niitä jopa ruokakasvien } \\
\text { kustannuksella. Kehitysmaissa on myös paljon halpaa työvoimaa, joka } \\
\text { tukee yritysten halua pitää kahviplantaasit köyhemmillä alueilla. Kahvin } \\
\text { kulutus sijoittuu sen hinnan ja kulutustottumusten vuoksi pohjoisemmille } \\
\text { alueille. Kahvikulttuuri on vahvaa esimerkiksi Pohjoismaissa, missä se } \\
\text { toimii kofeiinin vaikutuksesta piristeenä pimeinä aikoina ja lämmittävänä } \\
\text { juomana kylminä vuodenaikoina." [rekonstruoitu tyypillinen vastaus, } \\
\text { SOLO taso 4] }\end{array}$ & \\
\hline $\begin{array}{l}\text { 4A. } \\
\text { Relationaalisen } \\
\text { siirtymä }\end{array}$ & $\begin{array}{l}\text { ”Globalisaatiolla tarkoitetaan maailmanlaajuista } \\
\text { verkostoitumista eri alueiden välillä. } \\
\text { Vuorovaikutus lisääntyy ja kulttuurien, talouden, } \\
\text { politiikan sekä ympäristöasioiden leviämien } \\
\text { valtion rajojen yli lisääntyy. Ajatukset ja tavat } \\
\text { sekoittuvat ja yhteisiä piirteitä löytyy ihmisten } \\
\text { keskuudesta joka puolelta maailmaa. } \\
\text { Innovaatioiden ja median kehitys edistävät } \\
\text { globalisaatiota. } \\
\text { Rahakasvi tarkoittaa alueella yhden kasvin } \\
\text { viljelyyn keskittymistä. Rahakasveja ovat muun } \\
\text { muassa tupakka ja kahvi. Niitä viljellään } \\
\text { intensiivisesti mahdollisimman tehokkaasti ja } \\
\text { viljelmien tieltä raivataan usein muuta } \\
\text { kasvillisuutta, eikä alueella voi viljellä muita } \\
\text { tuotteita tehokkuuden laskemisen välttämiseksi. } \\
\text { Yksipuolinen viljely vie usein paljon maaperän } \\
\text { hedelmällisyydestä, mikä saattaa pilata sen } \\
\text { viljelymahdollisuudet pitkäksikin aikaa sen } \\
\text { jälkeen, mikäli rahakasvin viljely lopetetaan. } \\
\text { Rahakasvit on tarkoitettu pääosin vientiin, ja niistäa } \\
\text { saatavat tuotot menevät usein lähes sellaisenaan } \\
\text { monikansallisten yritysten tileille, eikä paikallisille } \\
\text { viljelijöille jää paljoakaan tuloja työstään. Tämän } \\
\text { vuoksi yhden kasvin viljely valtiossa saattaa } \\
\text { heilahduttaa koko valtiontaloutta merkittävästi, jos } \\
\text { sen arvolle tapahtuu merkittäviä muutoksia } \\
\text { maailmantalouden näkökulmasta.” [rekonstruoitu } \\
\text { tyypillinen vastaus, SOLO taso 4A] }\end{array}$ & $\begin{array}{l}\text { ”Kahvin tuotanto on suurta sellaisilla alueilla, joilla on otollinen ilmasto } \\
\text { viljellä sitä. Aineiston karttojen mukaan kahvia viljellään pääosin Keski- } \\
\text { Afrikassa, Etelä-Amerikassa ja Aasian eteläisissä̈ osissa sekä Oseaniassa. } \\
\text { Diagrammista nähdään myös, että kahvista saatavat tulot suhteessa valtion } \\
\text { kokonaistuloihin ovat korkeimpia Burundissa, Etiopiassa ja Ruandassa. } \\
\text { Ympäristöolot ja ilmastotekijät ovat otolliset kahvin viljelyyn. Ilma on } \\
\text { lämmin ja sademetsän alueilla trooppisella ja subtrooppisella vyöhykkeellä } \\
\text { usein tarpeeksi kostea. } \\
\text { Skandinavian maissa kahvin kulutus henkeä kohden on maailman korkein. } \\
\text { Suomessa useana vuotena jopa maailman korkein. Kahvia kulutetaan } \\
\text { kartan mukaan erityisesti juuri Pohjoismaissa kuten Ruotsissa, Suomessa } \\
\text { ja Norjassa, mutta myös etelämmissä maissa kuten Brasiliassa ja } \\
\text { Australiassa. Aineiston pohjalta voidaan päästä johtopäätökseen, ettäa } \\
\text { kahvia kulutetaan pääasiassa korkean tulotason maissa. Aineistossa on } \\
\text { myös useasta maasta vaillinainen otos, mikä vääristää todellisuutta ja } \\
\text { kokonaiskuvaa hieman. Korkean tulotason maissa ihmiset juovat kahvia } \\
\text { kahvista saatavan piristyksen ja mielihyvän vuoksi suuremmissa määrin, } \\
\text { mutta se on myös kautta aikojen ollut merkittävä seurustelujuoma. Lisäksi } \\
\text { kuluttajilla on yksinkertaisesti varaa kuluttaa enemmän korkean tulotason } \\
\text { maissa. Maat joissa kahvin tuotanto on tilaston mukaan yli } 5 \text { prosenttia } \\
\text { viennin arvosta, Väli-Amerikka ja Etiopia näyttäytyvät myöskin tuottavan } \\
\text { kahvia omille kotimaisille markkinoille merkittävissä määrin. } \\
\text { Kulutuksellisia ja tuotannollisia tekijöitä selittävät myös kehittyneisyyserot. } \\
\text { Entiset emämaat käyttivät siirtomaidensa alueita hyväksi raaka-aineiden } \\
\text { tuottamiseen, minkä vaikutus näkyy yhä tänäkin päivänä. Kehittyvät valtiot } \\
\text { eivät ole päässeet irti leimastaan, vaan ovat edelleen riippuvaisia } \\
\text { vientituotteidensa päätymisestä teollisuusmaihin. Joillekin valtioille juuri } \\
\text { kahvin tuottaminen on erityisen merkittävää, mikä nähdään diagrammin } \\
\text { tilastoista.” [rekonstruoitu tyypillinen vastaus, SOLO taso 4A] }\end{array}$ & $\begin{array}{l}\text { ”Reilu kauppa turvaa alueiden } \\
\text { viljelijöiden työolot sekä taloudellisen } \\
\text { tulon jatkumisen oikeudenmukaisena } \\
\text { globaaleilla markkinoilla. Reilun kaupan } \\
\text { sertifikaatti takaa, että kahvi on tuotettu } \\
\text { ihmisoikeuksia turvaavasti niin, että } \\
\text { taloudellinen oikeus on saavutettu } \\
\text { viljelijöiden tasolla. Reilu kauppa on } \\
\text { merkittävintä juuri viljelijän elinolojen } \\
\text { turvaamiselle. Vaikutukset ovat suuret } \\
\text { myös valtion tasolla, kun sen avulla } \\
\text { vähennetään myös esimerkiksi } \\
\text { lapsityövoiman käyttöä viljelmillä. Reilu } \\
\text { kauppa tukee myös ympäristön kestävää } \\
\text { käyttöä osana viljelyä. Kauppiaalle } \\
\text { tuotteet maksavat hieman enemmän, mutta } \\
\text { hyvä mainos auttaa lisäämään myyntiä ja } \\
\text { näin tuomaan lisää tuloja kauppiaalle. } \\
\text { Kuluttajat ovat usein valmiita maksamaan } \\
\text { korkeampia hintoja oikeudenmukaisesti } \\
\text { tuotetuista hyödykkeistä, kunhan he } \\
\text { tietävä, mihin rahat menevät. Tämää } \\
\text { osaltaan lisää myyntiä ja mahdollistaa } \\
\text { ehkä uusien reilun kaupan tuotteiden } \\
\text { saamisen markkinoille kauppiaan } \\
\text { toimesta." [rekonstruoitu tyypillinen } \\
\text { vastaus, SOLO taso 4A] }\end{array}$ \\
\hline $\begin{array}{l}\text { 5. Laaja } \\
\text { abstraktinen }\end{array}$ & - & - & - \\
\hline
\end{tabular}


LIITE 2. Rekonstruoidut tyypilliset vastaukset taloudellista kestävää kehitystä käsittelevään maantieteen ylioppilaskoekysymyksiin keväällä 2019, kysymys 6: Hiekka ehtyvänä luonnonvarana (Ylioppilastutkintolautakunta, 2020b).

\begin{tabular}{|c|c|c|c|}
\hline \multirow{2}{*}{$\begin{array}{l}\text { SOLO-taksonomian } \\
\text { taso }\end{array}$} & \multicolumn{3}{|c|}{ Kevät 2019, kysymys 6: Hiekka ehtyvänä luonnonvarana } \\
\hline & $\begin{array}{l}\text { 6.1 Mitä tarkoitetaan } \\
\text { kivennäismaalajeilla, ja miten } \\
\text { niitä luokitellaan? (4 p.) }\end{array}$ & $\begin{array}{l}\text { 6.2 Mihin hiekkaa tarvitaan, ja mitkä seikat vaikuttavat } \\
\text { hiekan kulutukseen? (12 p.) }\end{array}$ & $\begin{array}{l}\text { 6.3 Mitä taloudellisia, yhteiskunnallisia ja ympäristöongelmia hiekan } \\
\text { käyttöön luonnonvarana liittyy? Pohdi myös keinoja ongelmien } \\
\text { ratkaisemiseksi. (14 p.) }\end{array}$ \\
\hline $\begin{array}{l}\text { 1. Esirakenteinen } \\
\text { vastaus }\end{array}$ & $\begin{array}{l}\text { "Maaperä koostuu erilaisista } \\
\text { kivennäismaalajeista ja ne ovat } \\
\text { muodostuneet kivistä. Ne voidaan } \\
\text { luokitella syntytavan perusteella } \\
\text { esim. Kovassa paineessa on } \\
\text { syntynyt kerrostullinen kivi. Näitä } \\
\text { ovat esim. Hiekka, sora ja } \\
\text { moreeni." [rekonstruoitu } \\
\text { tyypillinen vastaus, SOLO taso 1] }\end{array}$ & $\begin{array}{l}\text { ”Hiekkaa tarvitaan paljon rakennusten. Niistä voi tehdä } \\
\text { keittiönpöytiä, tai sitä voi käyttää junan pysäyttämiseen. } \\
\text { Hiekkaa käytetään siis monessa jutussa. Kaupunkien } \\
\text { rakentamisessa käytetään paljon hiekkaa. Hiekkaa } \\
\text { käytetään sen syntytavan mukaan. Esimerkiksi kiderakenne } \\
\text { kertoo, mihin tarkoitukseen hiekkaa voi käyttää. Myös } \\
\text { hiekka voi tuoda lisätilaa mereen, jos siitä rakennetaan } \\
\text { lisää maata. Hiekkaa kuluu maissa, joissa on paljon rahaa } \\
\text { ja ne rakentavat liikaa rakennuksia. Myös hiekan } \\
\text { koostumus ja kemiallinen sisältö vaikuttaa kulutukseen". } \\
\text { [rekonstruoitu tyypillinen vastaus, SOLO taso 1] }\end{array}$ & $\begin{array}{l}\text { "Hiekan käyttöön liittyy seuraavat ongelmat. Ympäristön näkökulmasta } \\
\text { maiseman muokkaaminen. Tekemisessä otetaan maata pois pinnalta. Tästäa } \\
\text { syystä eläinten asumisalueet häviävät. Hiekan käyttöä vähentäisi se, ettei } \\
\text { ihmiset käyttäisi paljon hiekkaa. Hiekkaa käytetään paljon ja se on kallista. } \\
\text { Sitä kaivetaan paljon laillisesti ja laittomasti ja siksi se loppuu.", } \\
\text { [rekonstruoitu tyypillinen vastaus, SOLO taso 1] }\end{array}$ \\
\hline $\begin{array}{l}1 \mathrm{~A} . \\
\text { Esirakenteisen } \\
\text { siirtymävaihe }\end{array}$ & $\begin{array}{l}\text { "Kivennäismaalajit ovat kiviä } \\
\text { jotka ovat muodostuneet } \\
\text { esimerkiksi moreenista. } \\
\text { Kivennäismaalajeja luokitellaan } \\
\text { eloperäisiin ja ei-eloperäisiin } \\
\text { maalajeihin kuten multa, turve ja } \\
\text { muta tai niiden olemuksen } \\
\text { perusteella." [rekonstruoitu } \\
\text { tyypillinen vastaus, SOLO taso } \\
\text { 1A] }\end{array}$ & $\begin{array}{l}\text { ”Hiekkaa tarvitaan eniten rakennukseen ja teollisuuteen. } \\
\text { Niistä voi rakentaa kerrostaloja ja muita isoja ja pieniä } \\
\text { rakennuksia. Jos hiekasta rakentaa omakotitaloa, silloin } \\
\text { hiekkaa käytetään perustuksiin ja betonin valmistukseen. } \\
\text { Hiekkaa tarvitaan myös teiden hiekoittamiseen tai uusien } \\
\text { resorttien tekemiseen turisteille. Sitä tarvitaan myös maa- } \\
\text { alan laajentamiseen ja maanviljelyyn. Hiekan kulutukseen } \\
\text { vaikuttaa uudistuminen ja kuinka paljon sitä tarvitaan." } \\
\text { [rekonstruoitu tyypillinen vastaus, SOLO taso 1A] }\end{array}$ & $\begin{array}{l}\text { "Hiekka on kallista ja sitä tarvitaan paljon. Myös hiekan käytön } \\
\text { lisä̈̈ntyminen johtaa siihen, että kohta ei ole enää taloudellisesti } \\
\text { kannattavaa käyttää hiekkaa lainkaan. Rahan voisi käyttää johonkin, missäa } \\
\text { ei rakenneta. Rahaa jää siksi vähemmän asukkaiden käyttöön. Talouteen } \\
\text { hiekka vaikuttaa sekä positiivisesti että negatiivisesti. Hiekan käyttö lisää } \\
\text { ongelmia myös ympäristöön, koska se vaikuttaa sen alueen eläimiin, jotka } \\
\text { elää kuivilla alueilla. Hiekka tukahduttaa kasvillisuutta, eikä siinä pysty } \\
\text { elämään mikään. Käytön ongelmia on myös laittomat kaivaukset, koska se } \\
\text { on epäeettistä. Sen käyttöä pitäisi rajoittaa, koska se tukahduttaa } \\
\text { mereneläviä ja koralleja. Arabian autiomaan hiekka on liian hienojakoista, } \\
\text { että sitä voisi käyttää korvikkeena, mutta joku muu keino tulisi löytääa." } \\
\text { [rekonstruoitu tyypillinen vastaus, SOLO taso 1A] }\end{array}$ \\
\hline $\begin{array}{l}\text { 2. Yksinkertainen } \\
\text { vastaus }\end{array}$ & $\begin{array}{l}\text { "Kivennäismaalajeilla } \\
\text { tarkoitetaan kiviperäisiä } \\
\text { maalajeja, joissa kivet ovat } \\
\text { raekooltaan erilaisia. Niissä on } \\
\text { jonkinlaisia kivennäisaineita ja } \\
\text { mineraaleja." [rekonstruoitu } \\
\text { tyypillinen vastaus, SOLO taso 2] }\end{array}$ & $\begin{array}{l}\text { ”Hiekkaa käytetään rakennusten tekemiseen ja kasvien } \\
\text { viljelyyn. Sementin valmistukseen kuluu hiekkaa ja myös } \\
\text { maan tasaamiseen rakentamista varten. Sitä käytetään } \\
\text { Aasian rannikolla, jotta saadaan lisää tilaa kaupungille } \\
\text { mereltä, koska ihmisen populaation kasvun myötä } \\
\text { tarvitaan lisää elintilaa. Tähän kaikkeen kohdistuu ihmisen } \\
\text { hiekan käyttö. Hiekan kulutukseen vaikuttaa hiekan sijainti } \\
\text { ja käyttökohteen koko. Myös hiekan laatu ja hiekan määrä } \\
\text { maastossa vaikuttaa sen kulutukseen." [rekonstruoitu } \\
\text { tyypillinen vastaus, SOLO taso 2] }\end{array}$ & $\begin{array}{l}\text { "Hiekan runsas kuljettaminen laivoilla saastuttaa ilmastoa. Ruoppauksen } \\
\text { seurauksena pieniä saaria on kadonnut ja hiekasta on tehty lisää maata. } \\
\text { Koralliriuttoja ja monia eliöitä hautautuu hiekkaan, kun maa-alueita } \\
\text { siirretään merelle päin. Hiekan ansiosta kaupungit voivat kasvaa, mutta } \\
\text { luonto joutuu siirtyä kaupunkien tieltä. Jos maa on kaupitellut hiekkaa } \\
\text { laittomasti, voivat ongelmat kasautua kyseiselle maalle ja aiheuttaa sille } \\
\text { ongelmia. Taloudellisia ongelmia voi syntyä esimerkiksi hiekan verojen } \\
\text { vuoksi. Pimeät myyjät alkavat tienaamaan, kun laittomat kaivaukset tulevat } \\
\text { yhteiskunnalle ongelmaksi. Kun hiekka loppuu kokonaan, on vaikea etsiä } \\
\text { jotain korvaavaa tuotetta sen tilalle, joka on miinus sille valtiolle. }\end{array}$ \\
\hline
\end{tabular}




\begin{tabular}{|c|c|c|c|}
\hline & & & $\begin{array}{l}\text { Ongelman ratkaisemiseksi löytyy keinoja, mutta ihmiset eivät suostu } \\
\text { tekemään tällaisia tekoja. Voitaisiin kuitenkin etsiä jokin vaihtoehtoinen } \\
\text { materiaali, joka vähentäisi hiekan tarvetta tai sitten vähentää hiekan } \\
\text { käyttöä." [rekonstruoitu tyypillinen vastaus, SOLO taso 2] }\end{array}$ \\
\hline $\begin{array}{l}2 \mathrm{~A} . \\
\text { Yksinkertaisen } \\
\text { siirtymävaihe }\end{array}$ & $\begin{array}{l}\text { "Kivennäismaalajeja on } \\
\text { erityyppisiä kiviaineksesta } \\
\text { muodostuneita maalajeja. Ne ovat } \\
\text { elotonta maa-ainesta. Ne } \\
\text { luokitellaan niiden sisältämien } \\
\text { aineiden mukaan ja raekoko myös } \\
\text { vaikuttaa luokitteluun." } \\
\text { [rekonstruoitu tyypillinen vastaus, } \\
\text { SOLO taso 2A] }\end{array}$ & $\begin{array}{l}\text { ”Hiekka on tärkeä rakennusaine ja sitä käytetään sementin } \\
\text { ja betonin valmistuksessa. Hiekasta voi valmistaa myös } \\
\text { lasia. Sitä käytetään teiden pohjina, jotta tiet saadaan } \\
\text { katetuksi. Sitä käytetään myös satamia rakentaessa. } \\
\text { Kaakkois-Aasian saarivaltiot kuten Singapore käyttävät } \\
\text { valtavia määriä hiekkaa, koska ne haluavat laajentaa } \\
\text { maansa maa-alaa. Lisäksi tekosaaria ja rantoja tehdään } \\
\text { turisteja varten. Se, miten läheltä hiekkaa saadaan tuotua } \\
\text { alueelle, vaikuttaa hiekan kulutukseen. Rakennusyritykset } \\
\text { haluavat hiekkaa mahdollisimman läheltä, jolloin } \\
\text { lähialueen hiekkaa käytetään enemmän kuin muiden } \\
\text { alueiden. Maat kuten Kiina ja Intia tarvitsevat paljon } \\
\text { hiekkaa, joten hiekan tarve kasvaa koko ajan.”" } \\
\text { [rekonstruoitu tyypillinen vastaus, SOLO taso 2A] }\end{array}$ & $\begin{array}{l}\text { ”Jos hiekkaa ei ole saatavilla lähellä, se saattaa johtaa laittomiin } \\
\text { kaivauksiin. Aineistossa mainitaan, että laittomuuksia esiintyy sellaisilla } \\
\text { alueilla, joissa rakennetaan kovaa vauhtia. Laittomissa kaivauksissa on } \\
\text { myös ympäristöongelmia, koska niitä ei välttämättä ajatella tarkasti. } \\
\text { Jossain vaiheessa hiekka loppuu kokonaan ja silloin ei voida rakentaa } \\
\text { taloja, lentokenttiä ja teitä. Yhteiskunnallisia ongelmia tulee olemaan } \\
\text { sellaisilla valtioilla, jotka rakentavat liikaa, koska heiltä voidaan kieltää } \\
\text { rakentaminen kokonaan. Luonto kärsii hiekkakaivauksista ja ekosysteemit } \\
\text { voivat tuhoutua siellä, missä hiekkaa kaivetaan. Toinen hiekkapulan } \\
\text { ansioista tapahtuva ongelma tulee ehkä olemaan ilmastonmuutos, koska } \\
\text { hiekkaa kuljetetaan kaukaa laivoilla, jotka aiheuttavat päästöjä. Ongelmien } \\
\text { ratkaisemiseksi tulee keksiä korvaava aines, jota voi käyttää hiekan sijasta. } \\
\text { Monet maat ovat lopettaneet hiekan kuljettamisen muihin maihin. } \\
\text { Taloudellisesti ajateltuna hiekan hinta voisi nousta, jotta sen ostaminen } \\
\text { olisi vaikeampaa." [rekonstruoitu tyypillinen vastaus, SOLO taso 2A] }\end{array}$ \\
\hline $\begin{array}{l}\text { 3. Monirakenteinen } \\
\text { vastaus }\end{array}$ & $\begin{array}{l}\text { "Kivennäismaalajeilla } \\
\text { tarkoitetaan epäorgaanisia } \\
\text { maalajeja, jotka luokitellaan } \\
\text { raekoon mukaan esim. Sora, } \\
\text { hiekka, hieta, ja hiesu." } \\
\text { [rekonstruoitu tyypillinen vastaus, } \\
\text { SOLO taso 3] }\end{array}$ & $\begin{array}{l}\text { ”Hiekkaa tarvitaan eniten rakentamiseen ja teihin sekä } \\
\text { muihin infrastruktuurisiin hankkeisiin. Sitä tarvitsevat } \\
\text { suuret yritykset että yksittäiset ihmiset. Hiekasta saadaan } \\
\text { betonia, josta rakennetaan rakennusten perustoja. Hiekkaa } \\
\text { käytetä̈̈n myös asfaltin tekemiseen, mikä taas on tärkeä } \\
\text { elementti teiden rakentamisessa. Rakennuksia kohoaa } \\
\text { maailmaan jatkuvasti ja siksi hiekan tarve on niin suurta } \\
\text { koko ajan. Hiekkaa käytetään myös lasintekoon ja } \\
\text { hiekkarannoilla. Myös puistoihin tuodaan hiekkaa lasten } \\
\text { leikkipaikoille sekä esimerkiksi lampien hiekkapohjiksi ja } \\
\text { urheilukentille. Kuten uutisessa kerrotaan, hiekan käyttö } \\
\text { on lisäntynyt etenkin Itä- ja Kaakkois-Aasiassa. Myös } \\
\text { Lähi-Idässä hiekkaa on käytetty Burj Khalifan } \\
\text { rakentamiseen. Kulutukseen vaikuttavat kulutustottumukset } \\
\text { sekä käyttötavat. Myös hiekan hienojakoisuus vaikuttaa } \\
\text { siihen, kuinka paljon sitä voidaan käyttää. Koska nykyään } \\
\text { kaupungeissa rakennetaan yhä enemmän ja enemmän, } \\
\text { hiekan kulutus on nousussa. Etenkin kehitysmaissa, missä } \\
\text { rakentaminen on kiihtymässä, hiekkaa kuluu todella } \\
\text { paljon. Hiekan tarpeen nousu johtuu maiden kehityksestä." } \\
\text { [rekonstruoitu tyypillinen vastaus, SOLO taso 3] }\end{array}$ & 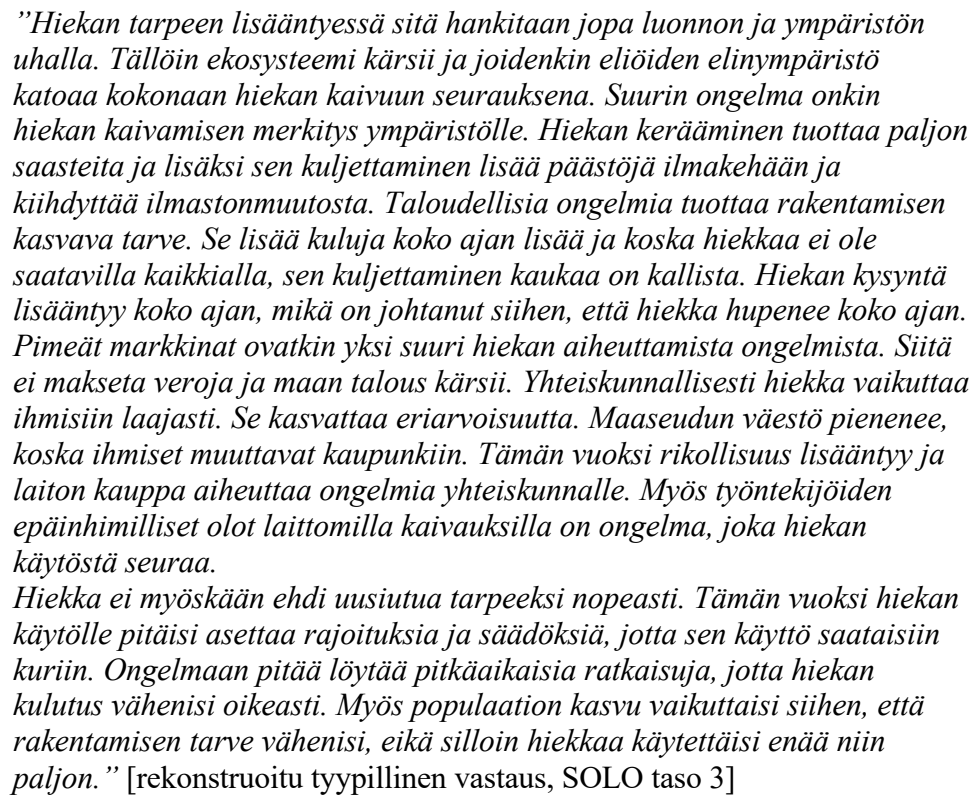 \\
\hline $3 \mathrm{~A}$. & "Kivennäismaalajit ovat & "Hiekka on veden ohella nyky-yhteiskunnan elinehto. & "6B-aineistossa kerrotaan, että hiekan käytöstä ollaan huolissaan. Sitä \\
\hline
\end{tabular}




\begin{tabular}{|c|c|c|c|}
\hline $\begin{array}{l}\text { Monirakenteisen } \\
\text { siirtymävaihe }\end{array}$ & $\begin{array}{l}\text { kallioperästä rapautunutta } \\
\text { irtonaista kiviainesta. Ne } \\
\text { koostuvat jostakin tiiviistä ja } \\
\text { kovasta aineksesta. } \\
\text { Kivennäismaalajien raekoko } \\
\text { vaihtelee. Kivennäismaalajeja } \\
\text { ovat muun muassa hiekka, sora, } \\
\text { savi ja moreeni. Moreeni on } \\
\text { näistä karkein. } \\
\text { Kivennäismaalajien vastakohtana } \\
\text { ovat eloperäiset maalajit." } \\
\text { [rekonstruoitu tyypillinen vastaus, } \\
\text { SOLO taso 3A] }\end{array}$ & $\begin{array}{l}\text { Sadevesi suodattuu valuessaan hiekan läpi ja lopulta siitä } \\
\text { muodostuu pohjavettä. Tämä on ihmiskunnalle tärkein } \\
\text { makean veden lähde. Luonnon muokkaamaa hiekkaa } \\
\text { käytetään paljon. Aavikoiden hiekka on liian hienojakoista, } \\
\text { jotta sitäa voitaisiin hyödyntää esimerkiksi rakentamisessa. } \\
\text { Hiekka on rakennusten perusta ja eniten hiekkaa käytetään } \\
\text { rakennusmateriaaleiksi. Yhteiskunnan tasolla hiekkaa } \\
\text { käytetään paljon kehittymässä olevissa valtioissa, kuten } \\
\text { Kiinassa ja Intiassa, koska niiden väestömäärä kasvaa } \\
\text { jatkuvasti ja ihmisiä muuttaa maalta kaupunkiin, sillä } \\
\text { maanviljely ei elätä heitä enää. Turistit arvostavat suuria } \\
\text { hiekkarantoja. Tällaisia paikkoja esiintyy esimerkiksi } \\
\text { Viron Pärnussa. Turisimiin panostamisessa rantojen } \\
\text { kehittämisessä saavutettaisiin parempi taloudellinen taso } \\
\text { yhteiskunnassa. Aineiston kuvasarjassa nähdään, miten } \\
\text { hiekan käyttö on merkittävää esimerkiksi Dubain Burj } \\
\text { Khalifa-rakennuksessa. Hiekkaa tarvitaan myös uusien } \\
\text { innovaatioiden kehittämisessä, kuten palmun muotoisen } \\
\text { parkkialueen rakentaminen mereen. Hiekkaa tarvitaan } \\
\text { myös täyttömaaksi ja koriste-elementtien rakentamiseen. } \\
\text { Teiden ja rakennusten kunnostaminen vie paljon } \\
\text { hiekkaresursseja. Hiekan kulutusta tulee myös luultavasti } \\
\text { lisäämään ilmastonmuutos. Kun jäätiköt sulavat ja } \\
\text { merenpinnan taso nousee, monet saaret ja kaupungit } \\
\text { peittyvät veden alle ja ihmisten pitää rakentaa uutta } \\
\text { asuintilaa mereen. Kaakkois-Aasian kaupunkivaltio } \\
\text { toteuttaa tätä hanketta askel askeleelta kohti merta." } \\
\text { [rekonstruoitu tyypillinen vastaus, SOLO taso 3A] }\end{array}$ & 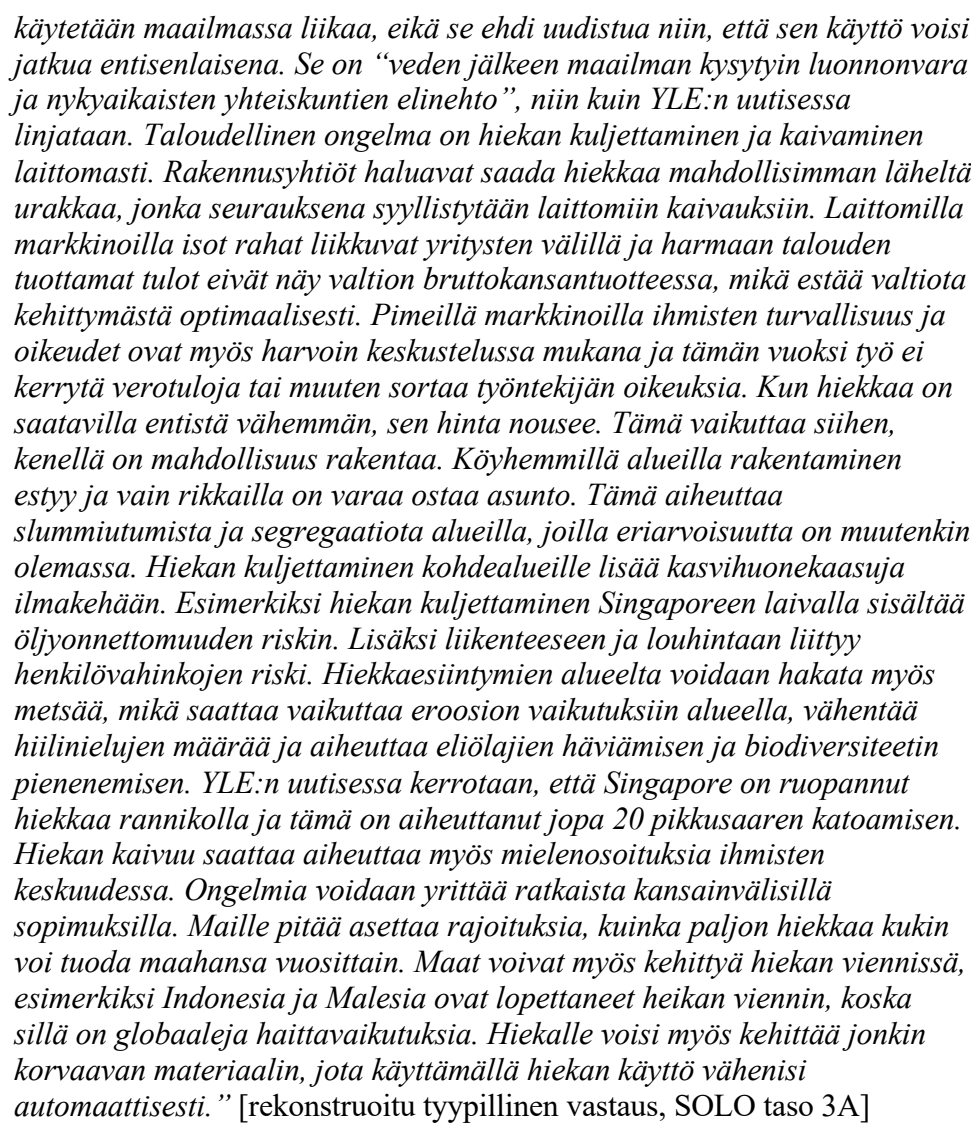 \\
\hline $\begin{array}{l}\text { 4. Relationaalinen } \\
\text { vastaus }\end{array}$ & $\begin{array}{l}\text { "Kivennäismaalajit ovat } \\
\text { kallioperästä irronnutta } \\
\text { kiviainesta eroosion ja } \\
\text { rapautumisen voimasta. Ne } \\
\text { jaetaan raekoon ja } \\
\text { hienojakoisuuden mukaan eri } \\
\text { lajeihin. Näitä ovat } \\
\text { suuruusluokissa suurimmasta } \\
\text { pienimpään sora, hiekka, hieta, } \\
\text { hiesu, savu ja lössi. Moreeni on } \\
\text { lajittumaton kivennäismaalaji, } \\
\text { jossa useaa eri raekokoa on } \\
\text { sekoittunut keskenään." }\end{array}$ & $\begin{array}{l}\text { "Hiekan kysyntä on korkeaa, koska sitä käytetään } \\
\text { infrastruktuurin ja rakennusten perustaksi. Kaikki tiet, } \\
\text { rakennukset ja junaradat on rakennettu vahvan ja } \\
\text { turvallisen perustan päälle, joka hiekasta on saatu } \\
\text { tuotettua. Hiekkaa käytetään betonin ja asfaltin } \\
\text { valmistuksessa. Hiekan kysyntä on maailmalla korkeaa } \\
\text { kaupungistumisen myötä. Etenkin kehittyvissä valtioissa } \\
\text { väestön kasvun seurauksena ihmiset muuttavat jatkuvasti } \\
\text { maalta kaupunkiin periferioilta ydinkeskuksiin, jolloin } \\
\text { asuntojen ja infrakstruktuurin rakentaminen on } \\
\text { ensisijaisen tärkeää. Kehitysmaiden talouden kehittyessä } \\
\text { on suuri tarve lisätä myös teollisuusalueita, tieverkkoja } \\
\text { sekä turismille merkittäviä alueita. Hiekkaa käytetään }\end{array}$ & $\begin{array}{l}\text { "Hiekan käyttö̈̈n liittyy paljon erilaisia ongelmia. Hiekan kysyntä on tällä } \\
\text { hetkellä niin korkeaa, että luonnon muovaama hiekka ei ehdi uusiutua } \\
\text { samalla tahdilla, kuin sitä ihminen käyttää. Tämän vuoksi hiekan } \\
\text { kaivaminen voi aiheuttaa alueilla aavikoitumista tehden näistä alueista } \\
\text { asuin- ja viljelykelvottomia. Pohjaveden laatu saattaa kärsiä, kun hiekan } \\
\text { suodattava ja puhdistava ominaisuus katoaa kaivannaisten takia. } \\
\text { Ympäristön monimuotoisuus kapenee, kun hiekankaivuualueilla muntetaan } \\
\text { eliöiden elinolosuhteita ja ekosysteemit kärsivät. Esimerkiksi Indonesiassa } \\
\text { hiekan ruoppaus kadotti yli } 20 \text { pikkusaarta kokonaan vieden mukanaan } \\
\text { kaikki niiden alueiden eliökunnat. Hiekan kuljetus tuottaa myös paljon } \\
\text { päästöjä, mikä osaltaan kiihdyttää ilmastonmuutosta. Hiekka halutaan } \\
\text { tuoda läheltä kuljetuskustannusten minimoimiseksi, mutta koska se ei aina } \\
\text { ole mahdollista, kaivuut voidaan suorittaa laittomasti. Tämä johtaa }\end{array}$ \\
\hline
\end{tabular}




\begin{tabular}{|c|c|c|c|}
\hline & $\begin{array}{l}\text { [rekonstruoitu tyypillinen vastaus, } \\
\text { SOLO taso 4] }\end{array}$ & $\begin{array}{l}\text { myös uuden maan luomiseen, kuten YLE:n uutiset ovat } \\
\text { kertoneet jutussa “Unohtakaa öljy, nyt loppuu hiekka" } \\
\text { (6.8.2017). Singapore on yksi merkittävimmistä hiekkaa } \\
\text { unden elintilan rakentamiseen käyttävä valtio, joka luo } \\
\text { uutta rakennuskelpoista maata, kun taas Yhdistyneet } \\
\text { Arabiemiirikunnat rakentaa näyttäviä ja korkeita } \\
\text { luksusrakennelmia ja saaria. Hiekkaa ei synny yhtä } \\
\text { nopeasti kuin sitä käytetään rapautumisen } \\
\text { pitkäkestoisuuden vuoksi. Hiekkavarannot ovat jakautuneet } \\
\text { epätasaisesti ympäri maailmaa. Tämän vuoksi hiekkaa } \\
\text { kuljetetaan paikasta toiseen kysynnän ja saatavuuden } \\
\text { mukaan. Väestönkasvu vaikuttaa myös paljon hiekan } \\
\text { kulutukseen, koska asuinpaikkojen tarve, tieverkkojen } \\
\text { rakentaminen sekä elintason nousu johtavat siihen, ettäa } \\
\text { hiekkaa tarvitaan etenkin kehittyvissä maissa jatkuvasti } \\
\text { enemmän. Kaupunkialueilla panostetaan myös esimerkiksi } \\
\text { viheralueiden rakentamiseen ja lisääntyvä turismi pakottaa } \\
\text { hiekan käytön lisäämistä alueilla, jotka kehittävät } \\
\text { ympäristöään otolliseksi turistien vierailuja varten. Yksi } \\
\text { hiekan kaivuun ongelmista on se, että kaikki hiekka ei } \\
\text { kelpaa, vaan sitä on tuotava kaukaakin sellaisille alueille, } \\
\text { missä käyttökelpoista hiekkaa ei ole lainkaan.” } \\
\text { [rekonstruoitu tyypillinen vastaus, SOLO taso 4] }\end{array}$ & $\begin{array}{l}\text { yhteiskunnallisiin ja taloudellisiin ongelmiin, kun pimeä kaupan arvo on } \\
\text { YLE:n uutisen mukaan jopa miljardeissa. Pimeitä markkinoita ei voi } \\
\text { kuitenkaan seurata kovin helposti ja siksi sen rajoittaminen on vaikeaa. } \\
\text { Lakia noudattavat yritykset joutuvat tuomaan hiekan kalliimmalla kuin } \\
\text { pimeän kaupan harjoittajat, mikä saattaa vaikuttaa valtion taloudelliseen } \\
\text { tilanteeseen negatiivisesti. Laittoman työn tekijät eivät myöskään tuo veroja } \\
\text { valtiolle, eikä heidän työturvansa ole yhtä korkea kuin laillisen työn tekijä. } \\
\text { Myös maisemallinen arvo laskee, kun heikkakaivaukset on toteutettu ilman } \\
\text { suunnitelmallisuutta ja alueet jäävät esteettisesti huonoon kuntoon, kun } \\
\text { kaivaukset päättyvät. Hiekkaan liittyvät markkinat ovat niin suuret, että } \\
\text { niiden ympärillä liikkuu jopa } 60 \text { miljardin euron edestä valuuttaa, YLE:n } \\
\text { uutinen kertoo. Hiekka liittyy välillisesti myös kuljetus- ja } \\
\text { rakennusbisnekseen. Ensisijainen ratkaisu on hiekan kulutuksen } \\
\text { vähentäminen. Tärkeää on hyödyntää olemassaolevaa rakennuskantaa } \\
\text { kierrättämällä ja korjaamalla ennemmin kuin uutta rakentamalla. Myös } \\
\text { muiden, esimerkiksi uusiutuvien luonnonvarojen käytön maksomointi } \\
\text { rakentamisessa vapauttaisi hiekkaan liittyvää painetta rakennusalalla ja } \\
\text { antaisi muita, kestävämpiä vaihtoehtoja rakentamiselle. Esimerkiksi puu on } \\
\text { hyvä rakennusvaihtoehto esimerkiksi Suomessa. Pimeät markkinat tulisi } \\
\text { olla valvotumpia ja niiden ympärille pitääa asettaa rajoituksia, joita } \\
\text { esimerkiksi kansainvälisillä sopimuksilla seurattaisiin.” [rekonstruoitu } \\
\text { tyypillinen vastaus, SOLO taso 4] }\end{array}$ \\
\hline $\begin{array}{l}\text { 4A. } \\
\text { Relationaalisen } \\
\text { siirtymä }\end{array}$ & - & - & - \\
\hline $\begin{array}{l}\text { 5. Laaja } \\
\text { abstraktinen }\end{array}$ & $\begin{array}{l}\text { "Kivennäismaalajit ovat } \\
\text { elottomasta maaperästä peräisin, } \\
\text { rapautumalla syntyneitä } \\
\text { maalajeja. Niitä luokitellaan } \\
\text { partikkelikoon eli raekoon } \\
\text { perusteella ja kivennäismaalajeja } \\
\text { ovat savi, hiesu, hieta, hiekka, } \\
\text { sora ja moreeni. Yksittäisen } \\
\text { kivennäismaalajirakeen koko voi } \\
\text { vaihdella millimetrin osasta } \\
\text { useisiin kymmeniin } \\
\text { senttimetreihin." [rekonstruoitu } \\
\text { tyypillinen vastaus, SOLO taso 5] }\end{array}$ & $\begin{array}{l}\text { "Kuten Ylen nettijutussa kerrotaan (YLE Uutiset } \\
\text { 6.8.2017), hiekka on merkittävä globaali kauppatavara ja } \\
\text { raaka-aine. Se on yksi tärkeimmistä ympäristön } \\
\text { muokkaamiseen käytetyistä elementeistä. Hiekkaa } \\
\text { tarvitaan yhteiskunnassa eniten rakentamiseen, } \\
\text { käytetyimmät hiekasta tuotetut rakennusaineet ovat betoni } \\
\text { ja asfaltti. Betonia ihminen käyttää rakennusten luomiseen, } \\
\text { kun taas asfaltti on tärkein tieverkkojen rakennuselementti. } \\
\text { Hiekasta voidaan rakentaa myös käyttötavaroissa } \\
\text { hyödynnettyjä elementtejä, kuten lasia. Hiekan avulla } \\
\text { voidaan myös muokata maastoa esimerkiksi rakennusten } \\
\text { alla tai tieverkkojen yhtenäistämiseksi tai rantaviivan } \\
\text { muokkaamiseen esimerkiksi turistikohteissa. YLE:n uutisen } \\
\text { mukaan hiekan avulla on lisätty esimerkiksi Singaporen } \\
\text { maa-alaa kasvavan väestön vuoksi, jotta asuintilaa } \\
\text { saataisiin lisää. Toisaalta, Arabiemiraattikunnat taas } \\
\text { rakentavat hulppeita pilvenpiirtäjiä ja kokonaan uusia, }\end{array}$ & $\begin{array}{l}\text { "Hiekan taloudelliset, ympäristölliset ja yhteiskunnalliset vaikutukset ovat } \\
\text { samankaltaisia kuin minkä tahansa muun luonnonvaran vastaavat. } \\
\text { Luonnonvarojen käyttö muodostaa selkeän ristiriidan: hiekkaa tarvitaan } \\
\text { jatkuvasti lisää ja enemmän, mutta toisaalta hiekan katsotaan olevan } \\
\text { uusiutumaton luonnonvara sen hitaan muodostumisen vuoksi. Fossiilisten } \\
\text { polttoaineiden tavoin havaitaan, että yhteiskunta on riippuvainen tästä } \\
\text { raaka-aineesta ja suurimmat ongelmat nousevat esiin sen riittävyydestä. } \\
\text { Aineiston mukaan hiekakamarkkinoiden arvo liikkuu } 60 \text { miljardissa } \\
\text { eurossa. Valtio, jonka alueella hiekkavarannot sijaitsevat, omaavat edun } \\
\text { markkinoilla, kun taas hiekattomien valtioiden pitää turvautua tuontiin. } \\
\text { Hiekka on siis merkittävä kauppatavara, jonka maantieteellinen sijainti on } \\
\text { merkittävä tekijä sen käyttömäärälle ja kysynnälle. Ongelmaksi hiekan } \\
\text { esiintyminen valtion alueella muodostuu silloin, kun se se on riippuvainen } \\
\text { juuri kyseisestä raaka-aineesta. Jos hiekan hinnan arvo laskee äkillisesti, } \\
\text { voi koko valtion talous heilahtaa merkittävästi tämän johdosta. Tällainen } \\
\text { koituu haitaksi usein raaka-aineiden tuottajamaille etenkin kehittyvillä } \\
\text { alueilla. }\end{array}$ \\
\hline
\end{tabular}




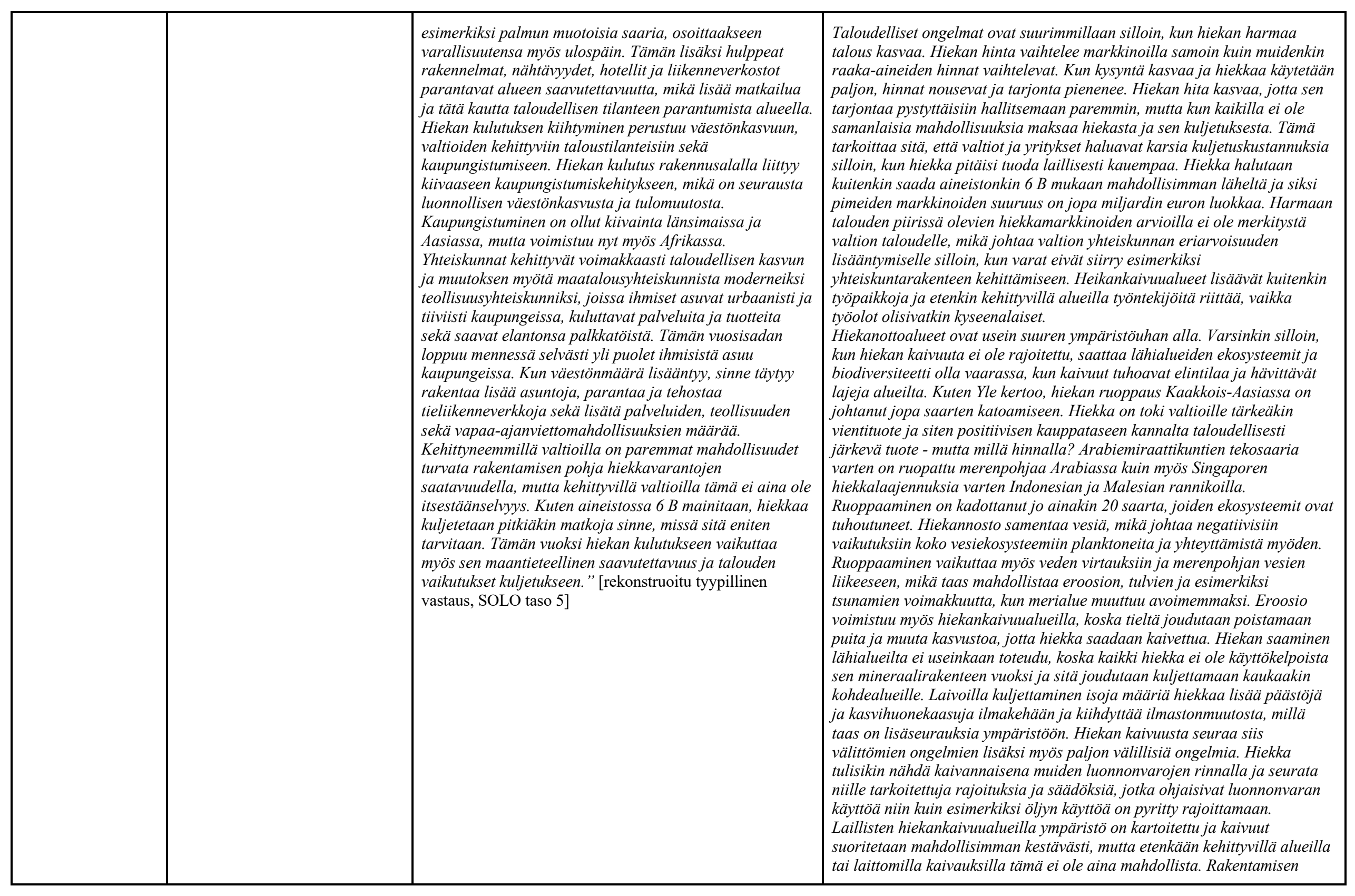




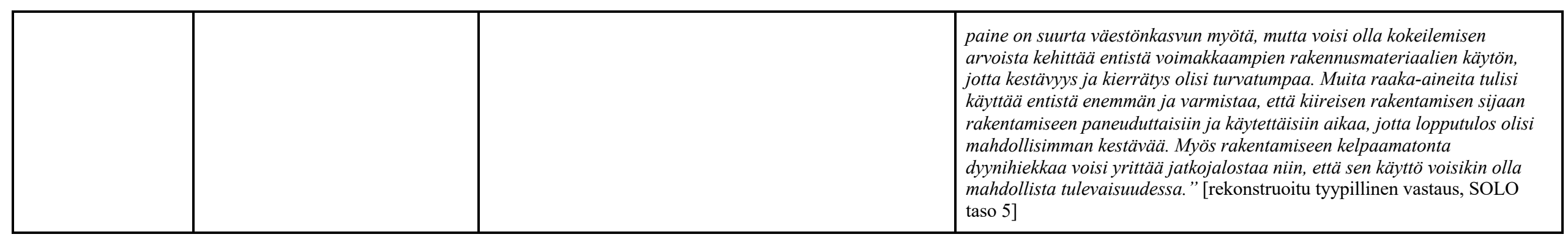

